\title{
O IMPACTO DO CRÉDITO RURAL NO DESENVOLVIMENTO DA CITRICULTURA NO ESTADO DE SÃO PAULO
}

\author{
JOSÉ NEWTON PIRES REIS \\ Engenheiro Agrônomo
}

Orientador: Prof. Dr. EVARISTO MARZABAL NEVES

\begin{abstract}
Tese apresentada à Escola Superior de Agricultura "Luiz de Queiroz", da Universidade de São Paulo, para obtenção do Título de Doutor em Agronomia, Área de Concentração: Economia Agrária.
\end{abstract}

PIRACICABA

Estado de São Paulo - Brasil Janeiro - 1995 
Ficta catalogrtatica oreparada pela Secalo de livros da

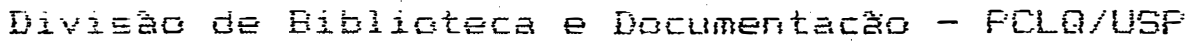

Feis, Jasé hewtar Fires fieis

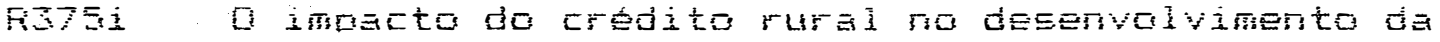

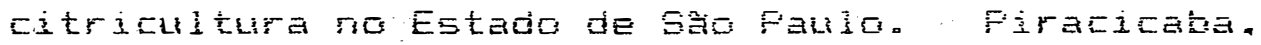
1975 .

F⿻.

TEEE - ESALS

Eibliogratia.

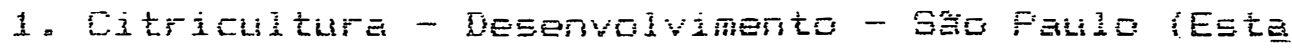
do) 2. Credito agricola - Sas Falido (EDtado\} I. Escola Suderior de Auricuitura Luiz de Guestoz. Firacicaba

CDD 33. 3745 


\section{O IMPACTO DO CRÉDITO RURAL NO DESENVOLVIMENTO DA CITRICULTURA NO ESTADO DE SÃO PAULO}

JOSÉ NEWTON PIRES REIS

Aprovada em: 14. 08.1995

Comissão julgadora:

Prof. Dr. Evaristo Marzabal Neves

Prof. Dr. José Vicente Caixeta Filho

Prof. Dr. Rodolfo Hoffmann

Prof. Dr. José Valdeci Biserra

Dr. Antônio Ambrósio Amaro
ESALQ/USP

ESALQ/USP

ESALQ/USP

UFC - CE

IEA

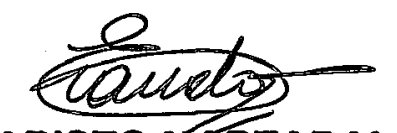

Prof. Dr. EVARISTOHARZABAL NEVES Orientador 
Aos meus pais, José Leopoldo e Maria Nailê, à minha esposa Magna e ao meu filho ícaro,

\section{DEDICO}




\section{AGRADECIMENTOS}

Ao Professor Evaristo Marzabal Neves, pela orientação e pelo incentivo que antecedeu e motivou a realização deste trabalho, incluindo a sugestão do tema.

Aos Professores Geraldo Sant'Ana de Camargo Barros, Rodolfo Hoffmann e José Vicente Caixeta Filho e ao Doutor Antônio Ambrósio Amaro, pelas valiosas críticas e sugestōes apresentadas.

A todos os colegas de curso, pelo elevado grau de companheirismo e amizade sempre presente nas horas mais dificeis.

Ao amigo Júlio César de Lemos, pela grande colaboração na elaboração do software utilizado neste trabalho.

Aos Professores e Funcionários do Departamento de Economia e Sociologia Ruràl, pelo companheirismo, ambiente de aprendizado e trabalho.

À Universidade Federal do Ceará, na pessoa dos Professores José Valdeci Biserra, Luiz Artur Clemente da Silva, Lúcia Maria Ramos Silva, Teobaldo Campos Mesquita e Ahmad Saeed Khan.

Por fim, agradeço ao CNPq e CAPES pela concessão de bolsa de estudo durante a realização do curso. 


\section{SUMÁRIO}

\section{Página}

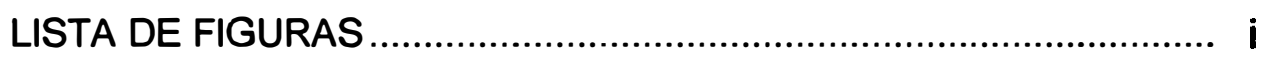

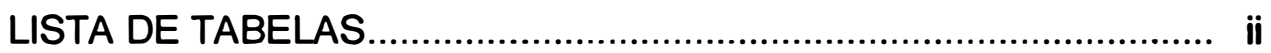

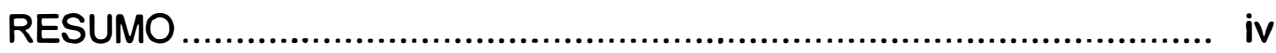

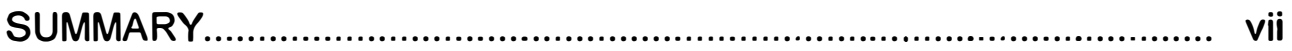

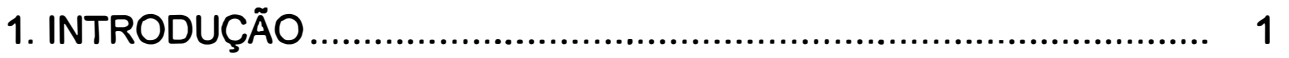

2. DEFINIÇÃO DO PROBLEMA E OBJETIVOS DA PESQUISA ........... 5

3. ANÁLISE DO DESENVOLVIMENTO DA CITRICULTURA

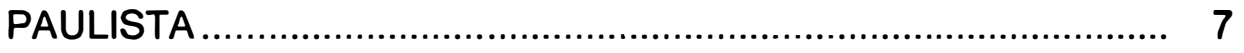

3.1. Considerações iniciais ........................................................... 7

3.2. O Complexo Industrial ....................................................... 10

3.3. Evolução Recente ............................................................. 14

4. ESTUDOS SOBRE MODELOS DE OFERTA PARA CULTURAS

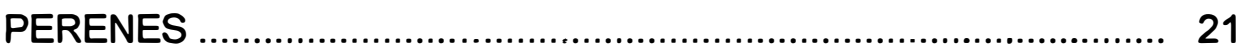

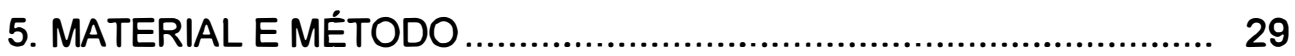

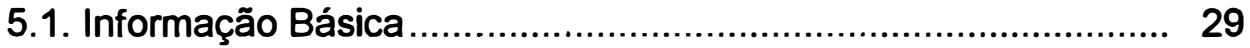

5.2. O Modelo Matemático ......................................................... 30

6. RESULTADOS E DISCUSSÃO …................................................... 45

6.1. Equação de novos plantios .................................................... 45

6.2. Equação de demanda por laranja pela indústria brasileira ......... 48

6.3. Resultados da simulação do modelo matemático....................... 49

6.3.1. Validação do modelo ..................................................... 49

6.3.2. Simulações dos cenários alternativos para o modelo

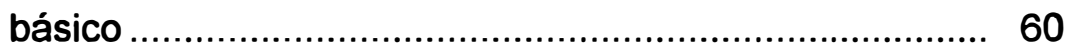


Página

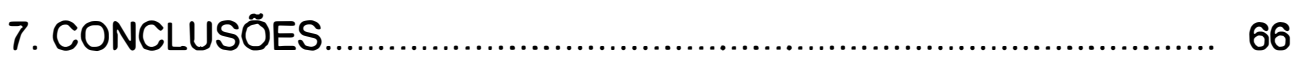

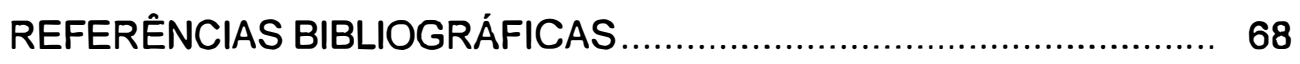

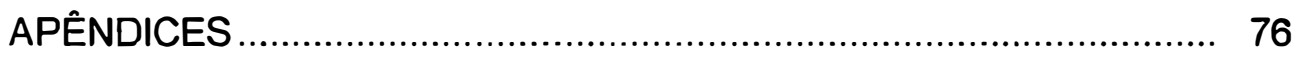




\section{LISTA DE FIGURAS}

Página

FIGURA 1 - Diagrama geral do processo de simulação

FIGURA 2 - SÃO PAULO: série histórica e série estimada de novos plantios, expressas em milhões de pés/ano, 1970/89.

FIGURA 3 - SÃO PAULO: produção histórica e produção simulada de laranja, milhöes de caixas $(40,8 \mathrm{~kg}), 1970 / 87$

FIGURA 4 - Demanda histórica e demanda simulada por laranja pela indústria brasileira, milhões de caixas (40,8kg), 1970/87

FIGURA 5 - SÃO PAULO: preço histórico e preço simulado da caixa de laranja recebido pelo produtor, US\$/caixa, 1970/87.

FIGURA 6 - SÃO PAULO: série histórica e série simulada de novos plantios, em milhões de pés, 1970/87

59

FIGURA 7 - Simulações - quantidade produzida de laranja no Estado de São Paulo, milhões de caixas, 1970/87

62

FIGURA 8 - Fluxograma geral do programa da simulação. 


\section{LISTA DE TABELAS}

Página

TABELA 1 - Produção de laranjas em 1000 toneladas dos cinco principais países produtores - 1969/91.

TABELA 2 - BRASIL - exportação de suco concentrado de laranja, segundo a participação percentual das principais regiões importadoras $1969 / 89$

TABELA 3 - Data das principais geadas ocorridas na Flórida

TABELA 4 - Evolução da área cultivada dos principais produtos, no Estado de São Paulo - média trienais (1967/69 - 1985/87), em 1000 ha... 16

TABELA 5 - LARANJA - SÃO PAULO: número de pés plantados e preço recebido pelo citricultor - 1969/89.

TABELA 6 - Produção (BRASIL) e processamento (SÃO PAULO) de laranja em milhões de caixas $(40.8 \mathrm{~kg})-1969 / 90$.

TABELA 7 - LARANJA - número de árvores e quantidade produzida no Estado de São Paulo - 1969/90

TABELA 8 - Estimativa dos parâmetros da equação de novos plantios de laranja - 1969/89

TABELA 9 - Estimativa dos parâmetros da equação de demanda por laranja pela indústria brasileira, 1968/87

TABELA 10 - BRASIL - distribuição da taxa de sobrevivência das árvores de laranja por idade 
Página

TABELA 11 - Simulação da quantidade produzida de laranja no Estado de São Paulo,em milhões de caixas (40,8kg), 1970/87

TABELA 12 - Simulação da demanda por laranja pela indústria brasileira, em milhões de caixas $(40,8 \mathrm{~kg}), 1970 / 87$.

TABELA 13 - Simulação do preço da caixa de laranja recebido pelos produtores, em dólares, 1970/87

TABELA 14 - Simulação do números de pés de laranja plantados no ano, no Estado de São Paulo, em milhões de pés, 1970/87.

TABELA 15 - Resultados da regressão linear dos valores históricos em função dos valores simulados

TABELA 16 - Quantidade de laranja produzida no Estado de São Paulo, em milhões de caixas $(40,8 \mathrm{~kg})$ : simulações no modelo básico e no modelo sem a participação do crédito rural, 1970/87

TABELA 17 - SÃO PAULO - número de pés de laranja plantados no ano, em milhões. Valores simulados no modelo básico e no modelo sem a participação do crédito rural, 1970/79

TABELA 18 - Demanda por laranja pela indústria brasileira, em milhões de caixas $(40,8 \mathrm{~kg})$. Valores simulados no modelo básico e no modelo sem a participação do crédito rural, 1970/87 


\title{
O IMPACTO DO CRÉDITO RURAL NO DESENVOLVIMENTO DA CITRICULTURA NO ESTADO DE SÃO PAULO
}

\author{
Autor: JOSÉ NEWTON PIRES REIS \\ Orientador: Dr. EVARISTO MARZABAL NEVES
}

\section{RESUMO}

O presente trabalho teve por objetivo desenvolver um modelo matemático adequado para culturas perenes e analisar sua aplicabilidade no estudo do desenvolvimento da citricultura paulista nas décadas de 70 e 80 , com ênfase na avaliação da política de crédito rural do governo brasileiro.

O problema foi analisado através da construção de um modelo envolvendo o equilibrio entre oferta e demanda no mercado paulista de laranja. Posteriormente, a análise foi enriquecida através da simulação dinâmica, que relacionou preços, oferta, demanda e novos plantios durante o periodo 1970 a 1987.

Para a especificação da oferta de laranja, construiu-se um modelo de resposta para culturas perenes, onde o processo de ajustamento no tempo é explicitado pelos novos plantios. Para a identificação dos fatores que influenciam nos novos plantios de laranja, em São Paulo, utilizou-se uma equação linear envolvendo diversas variáveis dependentes. A equação selecionada relacionou novos plantios ao crédito rural e à . razão entre os preços da caixa de laranja e da tonelada de cana-de-açúcar, recebidos pelos produtores. Os melhores resultados foram obtidos quando considerou-se a defasagem de um ano para as variáveis dependentes. 
Pelo lado da demanda, analisou-se o comportamento da indústria brasileira. Observaram-se resultados bastante satisfatórios em termos de ajuste da função, sugerindo a eficiência das variáveis selecionadas na explicação das variações da demanda interna por laranja pela indústria.

A simulação efetuada com a versão final do modelo ilustrou adequadamente o mercado em estudo, como indicam as avaliações do sistema. Durante o processo de validação do modelo, os melhores resultados foram encontrados quando se analisaram as variáveis quantidade produzida de laranja em São Paulo e demanda interna de laranja pela indústria. A reprodução dos valores históricos para as variáveis preço da caixa de laranja recebido pelos produtores e número de novos pés de laranja plantados no ano, também foi considerada aceitável.

Encerrou-se este trabalho considerando a questão de até que ponto a política de crédito agrícola subsidiado pelo governo brasileiro foi um fator decisivo no desenvolvimento do setor cítricola no Estado de São Paulo. Para tal, adotou-se um método de comparação gráfica, onde se eliminou do modelo o efeito do crédito agrícola subsidiado.

Conclui-se, através das simulações, que a política de crédito subsidiado foi importante para fortalecimento inicial do setor, pois, o cenário alternativo que desconsidera o crédito rural resultaria em menor produção de laranja em toda a década de 70 . 
Ressalta-se, porém, que a ausência de crédito não chegou a ser um fator decisivo para o seu crescimento, mesmo sem o estímulo creditício do governo, o próprio dinamismo do setor foi capaz de reproduzir uma agricultura e uma indústria compárável, em termos de demanda para processamento e produção de laranja, aos moldes vigentes ao final da década de 80. 


\title{
IMPACT OF AGRICULTURAL CREDIT ON CITRUS CROP IN THE STATE OF SÃO
}

PAULO

\author{
Author: JOSÉ NEWTON PIRES REIS \\ Adviser: Dr. EVARISTO MARZABAL NEVES
}

\section{SUMMARY}

The objective of this study was to develop a mathematical model adequate to permanent crops, and to analize an aplication to verify the influence of agricultural credit policy on citrus crop development in São Paulo during the decades of 70 and 80 .

The problem was analyzed by constructing a mathematical model of equilibrium between demand and supply in São Paulo orange market. Later on, the analysis was enriched by a dynamic simulation which related prices, supply, demand and new plantations during the period between 1970 and 1987.

To specify the supply of orange a response model specific to permanent crops was constructed. In that model, the process of time adjustment was made explicit by new crops. To identify factors responsible for new crops in São Paulo, it was used a linear equation model envolving various dependent variables. The selected equation showed relationship between agricultural credit and ratio of lagged prices of orange and sugarcane at producers level.

On the demand side, the behavior of brazilian orange industry was analysed. The results were very satisfactory in terms of function adjustment, suggesting efficiency of selected variables in explaining variation of internal demand of the orange's industry.. 
A simulation performed with the final verson of the model ilustraded the market in study, as indicated by system evaluations results. During the process of model validation, better results were obtained when variables such as quantity of orange produced in São Paulo and industry's internal demand for orange were considered. However, variables such as orange price (per box) received by orange producers and number of new orange trees planted within a year, also were considered acceptable.

The study finished by questioning the extent to which subsidized agricultural credit was a decisive factor in the development of citrus sector in the state of São Paulo. For this purpose, a method of graphic comparison was adopted, in which the effect of subsidized agricultural credit was eliminated.

Through simulation process, one could realize that the policy of subsidized credit was an important factor for the development, and the initial strengthen of the sector, as the orange production showed a declining trend under alternative sceneries when availability of subsidized agricultural credit was not considered.

It is important to mention that without credit incentives provided by government, sector's dynamic was able to reproduce agricultural and industrial activities comparable to those existing in the late eighties, in terms of demand. 


\section{INTRODUÇÃO}

No que diz respeito aos modelos de oferta agrícola, os problemas associados com formulações para estudar a dinâmica das culturas perenes têm até muito recentemente recebido pequena atenção' ${ }^{1}$. Um completo arcabouço teórico só apareceu na literatura há pouco tempo.

Antes de 1960 não houve quase nenhuma pesquisa nessa área². Todavia, alguns pesquisadores, particularmente French, têm feito contribuições significativas no estabelecimento de uma estrutura básica para estimar modelos de oferta para culturas perenes.

No Brasil, relativamente poucos estudos foram feitos nessa área, principalmente quando se considera o mecanismo de ajuste dinâmico da produção através de novos plantios.

Essa é a principal contribuição desta pesquisa, ou seja, a construção de um modelo matemático adequado para culturas perenes. A pesquisa pretende, ainda, analisar alguns condicionantes do desenvolvimento da citricultura paulista nas décadas de 70 e 80 , dando ênfase na avaliação da política de crédito agrícola subsidiado pelo governo federal brasileiro.

\footnotetext{
${ }^{1}$ Para se exemplificar, a maioria dos papers publicados sobre o tema no Journal of Farm Economics e American Journal of Agriculture Economics versam sobre medidas de funções de oferta para culturas anuais. Entre os mais comumente citados como referência estão NERLOVE (1956) e NERLOVE e BUCHMAN (1960).

2 Tem-se conhecimento de apenas dois trabalhos durante este periodo: o estudo de ADY (1949) que desenvolveu um modelo de oferta para a cultura do cacau, bastante criticado posteriormente por Bateman . E o estudo de FRENCH (1956), o qual desenvolveu uma função de oferta de longo prazo para maçãs nos Estados Unidos e Michigan.
} 
A citricultura ${ }^{3}$ é uma atividade de grande importância na economia brasileira, com o cultivo da laranja presente em vários Estados do país. A base do setor se concentra principalmente no Estado de São Paulo, que predomina tanto no cenário nacionăl quanto no cenário mundial.

A citricultura paulista experimentou um rápido crescimento nas últimas décadas. De acordo com dados do Instituto de Economia Agrícola (IEA), nos últimos 30 anos (1960 a 1989), a população citrícola aumentou em 1200\%, saltando de 13,5 milhões para 172,4 milhões de árvores. Nesse mesmo período, a produtividade cresceu $60 \%$. Atualmente, São Paulo é o principal produtor de laranja do pais, responsável por aproximadamente $85 \%$ da produção nacional.

O Estado de São Paulo, individualmente, quando comparado com países produtores, se torna o maior produtor. A produção paulista de laranja é, na sua maior parte, destinada à industrialização do suco, que basicamente (ao redor de 95\%) é exportada.

Apoiando-se em pesquisas recentes, NEVES (1992) destaca vários fatores como responsáveis por esse crescimento. Aponta vantagens comparativas relacionadas às condições climáticas, edafo-climáticas e sociais (mão-de-obra relativamente mais barata no Brasil); tradição na produção e exportação de laranja in natura; desenvolvimento na

\footnotetext{
${ }^{3}$ No mundo produz-se comercialmente oito espécies de citros: a laranja comum - Cïtrus sinensis $L_{\text {.. }}$ a tangerina (ou mexerica), o limão, a lima, o pomelo (ou grapefruit), a cidra, a toranja e a laranja azeda. Cada espécie tem dezenas de variedades e cultivares, além dos híbridos, alguns dos quais de expressão comercial, como a murcote e a "temple". Entretanto, não se faz neste trabalho a distinção entre citricultura que se refere à cultura de citros, e a produção estrita de laranja, pois, esta é a mais comum e a de maior importância econômica entre os citros.
} 
tecnologia agroindustrial e de comercialização do suco à granel no sistema tank-farm,; investimentos conjugados de produtores, comerciantes e indústrias, nacionais e estrangeiros, e, principalmente, às sucessivas geadas no Estado da Flórida - primeiro produtor americano e principal concorrente da citricultura paulista.

Contudo, estes fatores por si só, não podem ser os únicos elementos considerados na tentativa de se explicar o boom da citricultura brasileira. Também, devese ter em mente o fato de que, assim como os demais, esse setor está inserido no âmbito mais geral de modernização da agricultura brasileira, e que as estratégias globais de desenvolvimento afetam seus interesses específicos.

Com efeito, como bem afirma SHIROTA (1988), verifica-se que toda a política econômica voltada para o setor agrícola - da qual o crédito rural foi um dos componentes mais importantes em período mais recente - esteve finamente ajustada com os objetivos de desenvolvimento da economia como um todo. Mais do que isso, 0 setor agrícola foi, via de regra, utilizado como instrumento de viabilização dos programas de governo voltados para o setor urbano-industrial.

Na realidade, notadamente a partir da segunda metade dos anos 60 , observa-se a introdução de uma política agrícola mais consistente de estimulos, cujo leque é bastante amplo e sustentado. Nesse processo destaca-se a atuaçảo do governo através de um amplo sistema de incentivos creditícios, na maioria das vezes com juros negativos

\footnotetext{
${ }^{4}$ Atualmente ainda $20 \%$ do suco é transportado em tambores de aço. No sistema de transporte tankfarm (caminhōes-tanque, depósitos frigoríficos, navios sucoleiros), o suco fica entre 8 e $10^{\circ} \mathrm{C}$ abaixo de zero, que vai ser, também, a temperatura do navio e dos terminais. Nessa temperatura não há perigo de fermentação, nem o produto perde qualidade de sabor ou propriedades nutritivas.
} 
em termos reais, com o propósito de ampliar e modernizar a base técnica produtiva da agricultura e fomentar a criação e/ou expansão de sistemas agroindustriais 5 .

A princípio, espera-se pois, que o setor citricola tenha usufruído dos benefícios advindos dessa política flexivel do governo e, por conseguinte, é justificável algum esforço no sentido de investigar mais detalhadamente os resultados positivos da citricultura paulista, destacando-se o papel dos incentivos de créditos agrícolas subsidiados adotados pelas autoridades governamentais.

\footnotetext{
${ }^{5}$ Na política de crédito agrícola, adotada pelo governo, via crédito rural, estava implícita a idéia da existência de um estoque acumulado de conhecimentos tecnológicos e/ou que o sistema de pesquisa então existente estaria capacitado para atender a demanda por novas técnicas de produção. 0 mesmo raciocínio seria aplicado ao caso do sistema de extensão rural. Na verdade, o país tinha acabado de passar por um processo de substituição de importações que resultou em avanços significativos nos setores de máquinas agrícolas e fertilizantes. Havia, portanto, não só disponibilidade, mas a necessidade de aumentar sua demanda, viabilizando os pesados investimentos realizados pela sociedade. Assim, a politica de crédito rural viria constituir-se no elemento-chave do processo de modernização tecnológica da agricultura.
} 


\section{DEFINIÇÃO DO PROBLEMA E OBJETIVOS DA PESQUISA}

O presente trabalho visa, sobretudo, contribuir com novos métodos para a literatura dos modelos de resposta de culturas perenes, além da tentativa de uma compreensão mais adequada da citricultura paulista, quando relacionada a sua atividade básica: a produção de laranja.

Nos últimos decênios, criou-se uma situação excepcionalmente favorável à expansão da citricultura no Brasil. Fatores internos e externos que afetaram tanto a oferta como a demanda despertaram o interesse pelo incremento da produção local, contribuindo para a hegemonia brasileira na produção citricola nas décadas de 70 e 80 .

Por um lado, a oferta não-brasileira atravessou uma etapa de dificuldades sendo a produção norte-americana grandemente prejudicada por geadas, que praticamente destruiram os laranjais da Flórida. Logo, o explosivo crescimento em produção no Brasil, que ocorreu paralelamente à popularidade dos sucos citricos nos paises importadores, foi, também, incentivado pelo efeito estimulante dos preços no mercado internacional e ao produtor.

Por outro lado, a política comercial brasileira mudou substancialmente. Com o esgotamento do modelo de substituição de importação, o governo direciona sua prioridade aos setores agricola, energético e exportador.

De fato, convém ressaltar que o governo não adotou um programa de crédito específico para os produtores de citros, que se utilizaram do programa de crédito geral à agricultura. Todavia, tal estrutura de incentivos governamentais incorporada pela citricultura paulista na época de sua implantação, apesar de não ter sido diretamente 
concedida para o setor, pode ter repercutido sobre a produção de laranja. Além disso, pode ser que sem essas motivações, o setor não tivesse consolidado tão rapidamente 0 atual estágio de desenvolvimento, tornando-se uma das mais prósperas culturas do Estado.

Em vista do exposto, é justificável avaliar os efeitos específicos da política de crédito agrícola subsidiado sobre o desempenho do setor.

Dessa forma, os principais objetivos desse estudo são:

1. Analisar a evolução histórica do setor citricola paulista, como forma de localizar e interpretar problemáticas, bem como alertar para determinados riscos, limitações e incertezas associadas a caminhos alternativos de expansão futura;

2. Desenvolver um modelo matemático que reproduza adequadamente o funcionamento do mercado paulista de laranja;

3. Especificar empiricamente o modelo matemático e analisar sua validade para os anos recentes;

4. Demonstrar o uso do modelo no processo de simulação que visa revelar o impacto da polírica governamental de crédito agrícola subsidiado sobre o crescimento do setor. 


\section{ANÁLISE DO DESENVOLVIMENTO DA CITRICULTURA PAULISTA}

\subsection{CONSIDERAÇÕES INICIAIS}

Atualmente, além do privilégio de ter um "sabor universal", a laranja é o maior negócio de fruta do mundo. Os países atlânticos da América do Sul cultivam comercialmente citros há mais de um século. No Brasil, as primeiras plantas citricas foram introduzidas por volta de 1540 pelas primeiras expedições colonizadoras (MOREIRA, 1980).

Contudo, há sessenta anos atrás, São Paulo era apenas mais um ponto no mapa da citricultura mundial, que se constituia em mera atividade secundária em complemento às plantações de café. No início, a produção de citros destinava-se quase que exclusivamente ao consumo de subsistência. Entretanto, a partir de 1930, a possibilidade de exportação levou os citricultores a darem maior atenção à cultura, e a exploração da laranja in natura ganhou importância crescente no cenário econômico do Estado.

Já em 1930, a produção brasileira de laranja atingia cerca de $12 \%$ do total mundial, continuando a crescer até 1939, quando registrou a exportação de aproximadamente 5 milhões de caixas (AMARO,1980). 
No àno seguinte, inicia-se uma prolongada crise devido à $2^{a}$ Guerra Mundial, que paralisou quase todo tráfego marítimo ${ }^{6}$, e ao aparecimento da doença "tristeza", que dizimou grande parte dos laranjais paulistas?

O controle da "tristeza", a partir de 1953, com o uso de novos porta-enxertos resistentes à doença, e o rápido crescimento do comércio internacional no pós-guerra, permitiram aos produtores paulistas voltarem a expandir seus pomares. São Paulo já era o maior produtor de laranja do país em 1957 (ARANTES FILHO,1989), quando surgiu a séria ameaça do cancro cítrico, que veio novamente alterar as condições de desenvolvimento da citricultura através da erradicação de extensas plantações atingidas no sudoeste do Estado.

Apesar de tudo, cabe ressaltar que o Brasil, já no final da década de 50 , era o segundo maior produtor mundial de laranja e colocava-se entre os dez maiores exportadores de laranja in natura (ARANTES FILHO,1989).

Com o início da industrializacão da laranja, em São Paulo, a partir de 1963, começava uma nova etapa, onde o desenvolvimento das plantações passou a se dar de forma mais constante e crescente, fortalecida pelo maior nível organizacional, refletido

\footnotetext{
${ }^{6}$ Com a guerra, a citricultura paulista teve seu volume de exportações reduzidos e a falta de um mercado consumidor desanimou os citricultores, que deixaram de dispensar cuidados necessários aos pomares, aumentando a incidência de doenças e pragas ( MAIA, 1992).

${ }^{7}$ Até antes da segunda guerra, a citricultura brasileira usava como porta-enxerto, exclusivamente a laranja azeda. Veio então a "tristeza" e, dos cerca de 20 milhões de pés de laranja então existentes, 12 milhōes foram dizimados. A saída foi substituí-lo para o limão-cravo. Hoje, segundo RIBEIRO(1992), 95\% dos laranjais do Brasil usam o limão-cravo e vem sendo reclamada, pela maioria dos especialistas, uma diversificação de porta-enxertos.
} 
na postura empresarial adotada pelos participantes desse mercado. Ao mesmo tempo, para atender à nova conjuntura, verificou-se, neste periodo, nítida "fuga" dos mercados in natura, aumentando-se as tendências de plantio de variedades mais indicadas para a produção de sucos, como a pêra, valência,natal e hamlim.

Desta forma, as várias regiões produtoras e as diversas variedades plantadas complementam-se de forma harmoniosa, permitindo que em São Paulo se colha e comercialize frutas citricas boas, em quantidade e a preços baratos, durante o ano todo, fato que não se encontra na maioria dos outros países citrícolas ${ }^{8}$.

Como foi visto, a citricultura é hoje uma grande riqueza nacional. No entanto, não se pode esquecer que sofreu sérias vicissitudes em todo o longo período de desenvolvimento, as quais continuam a "assombrar" o setor, como o "declínio", a leprose, o cancro cítrico e, mais recentemente, a clorose variegada dos citros e o fungo estrelinha. Ademais, esgotou-se a fase intermitente de crescimento. Mais do que nunca se faz necessária a busca de ganhos de produtividade, a competência comercial e sobretudo a reestruturação dos apoios no campo tecnológico, agrícola e gerencial.

\footnotetext{
${ }^{8}$ Utilizando variedades precoces, tardias e de meia-idade, a safra da laranja no Brasil começa em junho-julho e vai até janeiro-fevereiro. Segundo a ASSOCITRUS - Associação Paulista dos Citricultores, nesses quase nove meses, emprega diretamente um contingente calculado em torno de 250 mil pessoas (45 mil só na colheita).
} 


\subsection{O COMPLEXO INDUSTRIAL.}

O melhor caso de sucesso recente da indústria brasileira é o suco de laranja. De acordo com GARCIA (1992), os fabricantes locais, de capital nacional e estrangeiro, respondem por $72 \%$ das exportações mundiais de suco concentrado.

$\mathrm{Na}$ balança comercial do país, o setor citrícola vem, anualmente, carreando mais de US\$ 1 bilhão (NEVES, 1992), ocupando lugar de destaque na economia não somente em termos de divisas mas também na geração de renda interna e empregos.

É um dos setores agroindustriais que mais se capitalizou nos últimos anos, com um produto bom na qualidade e no preço (RIBEIRO, 1992). Outros fabricantes, como os israelenses, têm que adicionar suco brasileiro em seu produto para atender exigências de paladar dos consumidores. E, mesmo tendo que pagar para entrar nos Estados Unidos uma sobretaxa de US $\$ 450$ por tonelada, o suco brasileiro compete bem com o produto da Flórida (GARCIA, 1991).

Entretanto, a história da indústria de sucos cítricos no Brasil é relativamente recente ${ }^{9}$. Os avanços de ordem econômica, social e tecnológica no pós-guerra levaram ao rápido desenvolvimento do produto concentrado, fazendo com que o perfil do consumidor se alterasse e a demanda se expandisse enormemente. Acréscimos de demanda nos Estados Unidos e diminuição da produção da Flórida, advinda de condições climáticas adversas, criaram a necessidade de se encontrar no mundo alternativas urgentes de produção de suco, que pudessem abastecer o mercado

\footnotetext{
${ }^{9} \mathbf{O}$ processamento industrial de citros em escala comercial iniciou-se na Itália há aproximadamente
} 170 anos (AMARO, 1973). 
americano, preenchendo o vazio deixado pelas fábricas americanas impossibilitadas de suprirem a procura de seus tradicionais clientes (AMARO, 1973).

A indústria encontrou em São Paulo um quadro perfeito. Os primeiros investimentos na atividade processadora deram-se nas regiões tradicionalmente cítricocafeeiras $^{10}$, que detinham as condições econômicas e sociais propícias, o que fez com que seus investimentos se concentrassem no "corredor da margem direita do Tietê" - o eixo Limeira, Araraquara, Matão e bebedouro.

Tudo começou em 1962, não por mera coincidência, no ano da primeira grande geada na Flórida, no município de Bebedouro, tem-se a primeira iniciativa relevante no processamento industrial da laranja, com a Companhia Mineira de Conservas. Ainda em 1962, na pressuposição de elevação dos preços desse suco nos mercados americano e europeu, a Toddy do Brasil fundou a Suconasa SIA no município de Araraquara. A iniciativa foi altamente compensadora e a "Suconasa" abriu caminho às principais firmas exportadoras de citros que implementaram novas indústrias em Matão e Bebedouro, sendo logo depois, seguidos pelas iniciativas pioneiras de citricultores de Limeira, Araras e Santo Antônio de Posse. Em 1976, funcionaram oito indústrias processadoras de laranja, todas no Estado de São Paulo (MOREIRA, 1980).

${ }^{10}$ A expansão regional da citricultura seguiu de perto a "rota cafeeira", aproveitando e ocupando as condições básicas de infra-estrutura operacional e econômico-financeira propiciadas pelo "complexo cafeeiro" (MARTINELLI, 1987). 
A primeira fase da indústria processadora termina em meados dos anos $70 \mathrm{com}$ a crise econômica deflagrada pela retração da demanda mundial, associada ao ajustamento do primeiro "choque" do petróleo. O marco desse periodo foi a falência da Sanderson S/A, em 1974, que causou certo abalo à citricultura. Contudo, com a intervenção do governo paulista, a confiança foi restabelecida. $O$ resultado desse processo foi a eliminação de pequenos capitais, com centralização industrial nos moldes oligopólico e oligopsônico. Segundo MARTINELLI (1989), somente os dois maiores grupos - Cutrale e Citrosuco - detinham $64 \%$ do total da capacidade de esmagamento e adquiriam mais de $60 \%$ de toda a laranja destinada ao processamento industrial.

Após a crise, inicia-se uma nova fase, onde se concretizam novos investimentos nas atividades produtiva e processadoral ${ }^{11}$. Essa fase caracteriza-se pelo crescimento exponencial da produção brasileira, acabando por transformar o Brasil, no início dos anos 80 , no maior produtor mundial de laranja (Tabela 1 ).

11 Em 1970, existiam 7 empresas com um total de 76 extratoras, número esse que passou em 1990 para 12 empresas com um total de 817 extratoras, indicando grande expansão do segmento em termos de capacidade instalada (MAIA, 1992). 
TABELA 1 - Produção de laranjas em 1000 toneladas dos cinco principais paises produtores, 1969 a 1991.

\begin{tabular}{|c|c|c|c|c|c|c|c|c|c|c|c|c|c|}
\hline ANO & BRASIL & $\%$ & EUA & $\%$ & ITÁLIA & $\%$ & MEXXICO & $\%$ & ESPANHA & $\%$ & $\begin{array}{l}\text { OUTROS } \\
\text { PAISES }\end{array}$ & $\%$ & Munsoo \\
\hline 1969 & 2360 & 9 & 7168 & 28 & 1423 & 5 & 1626 & 6 & 2187 & 8 & 10008 & 40 & 24774 \\
\hline 1970 & 2526 & 10 & 7278 & 29 & 1625 & 5 & 1254 & 5 & 1622 & 6 & 10554 & 43 & 24561 \\
\hline 1971 & 2654 & 10 & 7459 & 28 & 1462 & 5 & 1565 & 6 & 1840 & 7 & 10864 & 42 & 25847 \\
\hline 1972 & 3088 & 11 & 7472 & 27 & 1554 & 5 & 1613 & 5 & 2259 & 8 & 11296 & 41 & 27284 \\
\hline 1973 & 4018 & 13 & 8833 & 29 & 1507 & 5 & 1797 & 6 & 2080 & 7 & 11620 & 38 & 29858 \\
\hline 1974 & 4823 & 15 & 8514 & 27 & 1659 & 5 & 1420 & 4 & 920 & 6 & 12151 & 39 & 30490 \\
\hline 1975 & 5145 & 16 & 9294 & 29 & 1531 & 4 & 1615 & 5 & 2015 & 6 & 11720 & 37 & 31322 \\
\hline 1976 & 5842 & 17 & 9519 & 29 & 1795 & 5 & 1787 & 5 & 1805 & 5 & 12054 & 36 & 32804 \\
\hline $19 \pi 7$ & 5839 & 17 & 9567 & 29 & 1563 & 4 & 1856 & 5 & 1791 & 5 & 12187 & 37 & 32806 \\
\hline 1978 & 6378 & 19 & 8660 & 26 & 1433 & 4 & 1902 & 5 & 1651 & 5 & 12543 & 38 & 32568 \\
\hline 1979 & 6882 & 20 & 8309 & 24 & .1684 & 5 & 1902 & 5 & 1791 & 5 & 12847 & 38 & 33417 \\
\hline 1980 & 8876 & 23 & 8733 & 28 & 1539 & 4 & 1743 & 4 & 1711 & 4 & 13401 & 37 & 36004 \\
\hline 1981 & 9285 & 24 & 9513 & 25 & 1751 & 4 & 1788 & 4 & 1468 & 3 & 13904 & 36 & 37712 \\
\hline 1982 & 9452 & 26 & 6895 & 19 & 1497 & 4 & 1994 & 5 & 1703 & 4 & 14685 & 40 & 36228 \\
\hline 1983 & 9543 & 24 & 8635 & 21 & 2298 & 5 & 2068 & 5 & 2081 & 5 & 14958 & 37 & 39588 \\
\hline 1984 & 13771 & 34 & 6573 & 16 & 1557 & 4 & 1453 & 3 & 1352 & 3 & 14942 & 38 & 39250 \\
\hline 1985 & 11572 & 30 & 6095 & 15 & 1850 & 4 & 2000 & 5 & 1905 & 4 & 11113 & 39 & 38535 \\
\hline 1986 & 13321 & 32 & 6895 & 16 & 2190 & 5 & 1410 & 3 & 2048 & 4 & 15654 & 37 & 41438 \\
\hline 1987 & 14670 & 34 & 6983 & 16 & 1343 & 3 & 741 & 2 & 2442 & 6 & 17206 & 39 & 43385 \\
\hline 1988 & 13300 & 30 & 7386 & 16 & 2008 & 4 & 2268 & 5 & 2231 & 5 & 18160 & 40 & 45353 \\
\hline 1989 & 17774 & 34 & 8118 & 15 & 2066 & 4 & 1166 & 2 & 2676 & 5 & 20938 & 40 & 48800 \\
\hline 1990 & 11960 & 25 & 7258 & 16 & 1800 & 4 & 2400 & 5 & 2576 & 5 & 20912 & 45 & 46906 \\
\hline 1991 & 12362 & 25 & 7258 & 14 & 2039 & 4 & 2230 & 4 & 2748 & 5 & 24494 & 48 & 50898 \\
\hline
\end{tabular}

FONTE: ARANTES FIL.HO (1989)

Atualmente, a indústria brasileira tem feito grande esforço para ampliar seus mercados em outros paises, sobretudo na Europa, mas também em regiões não tão tradicionais como paises da Ásia e da África. Hoje nem são mais os EUA nosso maior comprador de suco; a Europa já está em primeiro lugar (Tabela 2) e há grande expectativa sobre aumento das encomendas do Japão, dos Tigres Asiáticos e da antiga União Soviética. 
TABELA 2 - BRASIL: exportação de suco concentrado de laranja, segundo a participação percentual das principais regiões importadoras, 1969 a 1989.

\begin{tabular}{ccccc}
\hline ANO & EUA & CEE $^{*}$ & OUTROS & TOTAL \\
\hline $\mathbf{6 9}$ & 12.1 & 60.6 & 27.3 & 100.0 \\
$\mathbf{7 0}$ & 3.0 & 72.9 & 24.1 & 100.0 \\
$\mathbf{7 1}$ & 30.3 & 51.4 & 18.3 & 100.0 \\
$\mathbf{7 2}$ & 20.3 & 57.5 & 22.2 & 100.0 \\
$\mathbf{7 3}$ & 9.1 & 70.3 & 20.6 & 100.0 \\
$\mathbf{7 4}$ & 21.3 & 53.3 & 25.4 & 100.0 \\
$\mathbf{7 5}$ & 10.5 & 54.7 & 34.8 & 100.0 \\
$\mathbf{7 6}$ & 9.9 & 60.8 & 29.3 & 100.0 \\
$\mathbf{7 7}$ & 20.1 & 48.8 & 31.1 & 100.0 \\
$\mathbf{7 8}$ & 42.2 & 29.0 & 28.8 & 100.0 \\
$\mathbf{7 9}$ & 26.2 & 43.6 & 30.2 & 100.0 \\
$\mathbf{8 0}$ & 19.7 & 53.7 & 26.6 & 100.0 \\
$\mathbf{8 1}$ & 40.6 & 45.7 & 13.7 & 100.0 \\
$\mathbf{8 2}$ & 57.2 & 28.0 & 14.8 & 100.0 \\
$\mathbf{8 3}$ & 46.3 & 36.9 & 16.8 & 100.0 \\
$\mathbf{8 4}$ & 62.8 & 25.9 & 11.3 & 100.0 \\
$\mathbf{8 5}$ & 59.1 & 28.4 & 12.5 & 100.0 \\
$\mathbf{8 6}$ & 51.3 & 38.1 & 10.6 & 100.0 \\
$\mathbf{8 7}$ & 43.4 & 44.8 & 11.8 & 100.0 \\
$\mathbf{8 8}$ & 38.9 & 48.9 & 12.2 & 100.0 \\
$\mathbf{8 9}$ & 35.6 & 46.4 & 18.0 & 100.0 \\
\hline
\end{tabular}

FONTE: CACEX

* CEE= Comunidade Econômica Européia

\subsection{EVOLUÇÃO RECENTE}

Os últimos vinte e cinco anos caracterizaram-se por uma crescente demanda por laranja, estimulada pela industrialização e urbanização, tendo a citricultura iniciado um processo de evolução que se acentuou de forma significativa a partir de 1970, apesar de certas tendências se manifestarem desde anos anteriores.

A expansão dos laranjais ia realizando-se em ritmo normal, sob iniciativas de aperfeiçoamento do mercado interno e sob o influxo da retomada da exportação para os mercados europeu e canadense, em difícil competição com os citros de outras procedências, especialmente da África do Sul. Foi quando no inverno de 1962/63, forte 
geada causou enormes prejuizos aos laranjais da Flórida e abriu brilhantes perspectivas para o futuro dessa atividade no Brasil (Tabela 3).

TABELA 3 - Data das principais geadas ocorridas na Flórida.

\begin{tabular}{|c|c|}
\hline ANO & DATA \\
\hline 1962 & $13 / 12 / 62$ \\
\hline 1971 & $19 / 01 / 71$ \\
\hline 1977 & $17 / 01 / 77$ \\
\hline 1981 & $12 / 01 / 81$ \\
\hline 1982 & $11 / 01 / 82$ \\
\hline 1983 & $24 / 12 / 83$ \\
\hline 1985 & $21 / 01 / 85$ \\
\hline 1989 & $23 / 12 / 89$ \\
\hline
\end{tabular}

FONTE: FRUTESP(1994)

Neste sentido, o estabelecimento de uma avançada tecnologia baseada na pesquisa e experimentação dos mais modernos métodos de cultivo e produção, fruto da conjugação de esforços dos órgãos governamentais e privados, proporcionou condições de tal segurança econômica que poderosas firmas, ao lado dos citricultores tradicionais, lançaram-se ao plantio de extensas áreas, sob as mais diversas condições. Dessa maneira, surgiram pomares comparáveis ao que de melhor existia nos mais avançados países citrícolas.

Observa-se pelos dados da Tabela 4 a grande evolução da cultura da laranja. A área com laranja no Estado de São Paulo cresceu cerca de $850 \%$, entre $1967 / 69$ e 1985/87, abaixo apenas da soja. 
TABELA 4 - Evolução da área cultivada dos principais produtos, no Estado de São Paulo - média trienais (1967/69 - 1985/87), em 1000 ha.

\begin{tabular}{llllllllll}
\hline ANOS & ALGODĀO & ARROZ & CAFE & CANA & FEIJĀO & MILHO & SOJA & LARANJA & TOTAL \\
\hline $\mathbf{6 7 / 6 9}$ & 448.9 & 721.1 & 785.2 & 496.0 & 243.2 & 1332.8 & 34.7 & 76.9 & 4491.4 \\
$\mathbf{7 0 / 7 2}$ & 594.3 & 613.9 & 719.5 & 544.0 & 242.7 & 1357.2 & 78.9 & 105.1 & 5078.2 \\
$\mathbf{7 3 / 7 5}$ & 421.2 & 506.0 & 659.3 & 676.3 & 263.8 & 1232.7 & 309.3 & 271.4 & 4889.3 \\
$\mathbf{7 6 / 7 8}$ & 289.5 & 431.6 & 605.7 & 794.8 & 358.3 & 1118.7 & 467.7 & 298.4 & 4888.1 \\
$\mathbf{7 9 / 8 1}$ & 285.5 & 305.1 & 813.9 & 1025.6 & 452.7 & 1077.7 & 546.3 & 397.2 & 4438.5 \\
$\mathbf{8 2 / 8 4}$ & 290.2 & 327.9 & 665.7 & 1458.0 & 543.7 & 1258.1 & 489.7 & 471.5 & 5803.1 \\
$\mathbf{8 5 / 8 7}$ & 334.7 & 302.6 & 806.9 & 2136.5 & 461.7 & 1343.4 & 483.5 & 727.9 & 6597.2 \\
\hline
\end{tabular}

FONTE: Anuários Estatísticos (IBGE)

Pesquisa recente, desenvolvida pelo Instituto de Economia Agrícola, citada por NEVES (1992), concluiu que o crescimento na área plantada não se realizou com a incorporação de áreas novas, via ocupação de fronteira agrícola, mas sim pela substituição de outras atividades. A pesquisa determina 0 efeito-escala e 0 efeitosubstituição para o sistema de produção agrícola do Estado de São Paulo. A obtenção de valores negativos para a escala, para 17 culturas analisadas, evidencia, para um período de dez anos (1978/79 a 1988/89), esgotamento da fronteira agrícola externa. No que concerne à substituição, seis culturas apresentaram resultados positivos. A laranja posicionou-se em terceiro lugar, logo após cana-de-açúcar e pastagens artificiais.

O aumento anual das áreas plantadas em São Paulo, que vinha sendo rápido até 1965, passou a ser febril, registrando a partir de 1970 plantações de alguns milhões de árvores por ano, elevando o Brasil à posição de maior produtor mundial de laranjas no início dos anos 80, sobrepujando os Estados Unidos, que lideravam a produção praticamente desde o final do século XIX. Verifica-se que, nesse período, o número de pés novos em relação ao total atingiu o ápice em $37 \%$, no ano de 1974 , quando foram plantadas 13,5 milhões de mudas. Contudo, o maior incremento ocorreu no ano agrícola de $1978 / 79$ com 15,9 milhões de mudas plantadas. Em paralelo com os preços recebidos pelos citricultores, verifica-se que esses plantios ocorreram justamente após 
anos de elevação nas cotações, fortalecendo o ânimo dos citricultores na expansão dos pomares (Tabela 5).

TABELA 5 - LARANJA (SÃO PAULO): número de pés plantados e preço recebido pelo citricultor, 1969 a 1989.

\begin{tabular}{ccc} 
ANO & $\begin{array}{c}\text { PES PLANTADOS NO ANO } \\
\text { (mil pés) }\end{array}$ & $\begin{array}{c}\text { PRECCO RECEBIDO PELO } \\
\text { CITRICULTOR (Us\$ICX) }\end{array}$ \\
\hline 1969 & 7395 & 1.43 \\
1970 & 6170 & 0.88 \\
1971 & 5000 & 1.01 \\
1972 & 6200 & 1.10 \\
1973 & 6300 & 1.48 \\
1974 & 13518 & 0.85 \\
1975 & 4260 & 1.00 \\
1976 & 5865 & 1.10 \\
1977 & 4725 & 2.20 \\
1978 & 8058 & 2.00 \\
1979 & 15941 & 2.00 \\
$1980^{*}$ & 7950 & 1.60 \\
1981 & 5500 & 2.20 \\
1982 & 5900 & 1.90 \\
1983 & 6100 & 1.48 \\
1984 & 3900 & 2.74 \\
1985 & 7400 & 3.50 \\
1986 & 8000 & 1.15 \\
1987 & 5000 & 2.41 \\
1988 & 8900 & 3.74 \\
1989 & 15800 & 3.53 \\
\hline
\end{tabular}

FONTE: Informaçôes Econômicas, IEA

* A partir de 1980, os dados para pés plantados no ano são ajustados a partir de informações da ABECITRUS - Associação Brasileira dos Exportadores de Cítricos e do IEA que publica dados referentes a número de pés novos incluindo árvores com menos de 3 anos de idade.

Esse desenvolvimento do setor foi acompanhado por grandes mudanças na estrutura da absorção da oferta. O aspecto mais relevante foi a preponderante participação do processamento industrial da fruta, que de $15 \%$ da produção em 1970 passou a representar cerca de $65 \%$ no início da década de 80 (Tabela 6). 
TABELA 6 - Produção (BRASIL) e processamento (SÃO PAULO) de laranja em milhões de caixas(40,8 kg), 1969 a 1990.

\begin{tabular}{cccc}
\hline ANO & PRODUCAO & PROCESSAMENTO & $\%$ \\
\hline $\mathbf{1 9 6 9}$ & 80 & 9 & 11.25 \\
$\mathbf{1 9 7 0}$ & 99 & 15 & 15.15 \\
$\mathbf{1 9 7 1}$ & 95 & 23 & 24.21 \\
$\mathbf{1 9 7 2}$ & 115 & 34 & 29.57 \\
$\mathbf{1 9 7 3}$ & 98 & 35 & 35.71 \\
$\mathbf{1 9 7 4}$ & 137 & 49 & 35.77 \\
$\mathbf{1 9 7 5}$ & 128 & 53 & 41.41 \\
$\mathbf{1 9 7 6}$ & 140 & 67 & 47.86 \\
$\mathbf{1 9 7 7 7}$ & 135 & 62 & 45.93 \\
$\mathbf{1 9 7 8}$ & 195 & 117 & 60.00 \\
$\mathbf{1 9 7 9}$ & 212 & 124 & 58.49 \\
$\mathbf{1 9 8 0}$ & 217 & 138 & 63.59 \\
$\mathbf{1 9 8 1}$ & 228 & 155 & 67.98 \\
$\mathbf{1 9 8 2}$ & 244 & 161 & 65.98 \\
$\mathbf{1 9 8 3}$ & 245 & 165 & 67.35 \\
$\mathbf{1 9 8 4}$ & 252 & 185 & 73.41 \\
$\mathbf{1 9 8 5}$ & 287 & 220 & 76.66 \\
$\mathbf{1 9 8 6}$ & 265 & 163 & 61.51 \\
$\mathbf{1 9 8 7}$ & 294 & 180 & 61.22 \\
$\mathbf{1 9 8 8}$ & 274 & 175 & 63.86 \\
$\mathbf{1 9 8 9}$ & 357 & 252 & 70.58 \\
$\mathbf{1 9 9 0}$ & 323 & 204 & 63.15 \\
\hline
\end{tabular}

FONTE: Horticultural Products Review, USDA

Na década de oitenta, a produção brasileira de laranja passou de 54,5 bilhões de frutos em 1980 para 88,9 bilhões em 1990. O principal fator de crescimento da cultura foi o aumento da área cultivada que foi da ordem de $4,71 \%$ ao ano. O crescimento na produtividade, em torno de $0,3 \%$ ao ano, foi pouco significativo, correspondendo a um aumento de 3.000 frutos/ha entre 1980 e 1990 (SOUZA et alii, 1990).

Com isso, em 20 anos, a citricultura do Estado de São Paulo passou de 33 milhões de pés para cerca de 160 milhões, responsáveis por mais de 200 milhões de caixas de laranja (Tabela 7). 
TABELA 7 - Número de árvores e quantidade produzida de laranja no Estado de São Paulo, 1969 a 1990.

\begin{tabular}{ccc} 
ANO & $\begin{array}{c}\text { NUMERO DE ARVORES } \\
\text { (milhöes) }\end{array}$ & $\begin{array}{c}\text { QUANTIDADE PRODUZIDA } \\
\text { milhöes de caixas(40,8 kg) }\end{array}$ \\
\hline $\mathbf{1 9 6 9}$ & 33 & 35 \\
$\mathbf{1 9 7 0}$ & 39 & 44 \\
$\mathbf{1 9 7 1}$ & 44 & 46 \\
1972 & 50 & 61 \\
$\mathbf{1 9 7 3}$ & 57 & 62 \\
$\mathbf{1 9 7 4}$ & 70 & 82 \\
$\mathbf{1 9 7 5}$ & 74 & 85 \\
$\mathbf{1 9 7 6}$ & 76 & 100 \\
$\mathbf{1 9 7 7}$ & 79 & 92 \\
$\mathbf{1 9 7 8}$ & 87 & 150 \\
$\mathbf{1 9 7 9}$ & 103 & 155 \\
1980 & 106 & 170 \\
$\mathbf{1 9 8 1}$ & 106 & 180 \\
$\mathbf{1 9 8 2}$ & 108 & 195 \\
$\mathbf{1 9 8 3}$ & 113 & 200 \\
$\mathbf{1 9 8 4}$ & 117 & 205 \\
$\mathbf{1 9 8 5}$ & 129 & 239 \\
$\mathbf{1 9 8 6}$ & 136 & 220 \\
$\mathbf{1 9 8 7}$ & 139 & 210 \\
$\mathbf{1 9 8 8}$ & 156 & 249 \\
$\mathbf{1 9 8 9}$ & 172 & 297 \\
$\mathbf{1 9 9 0}$ & 152 & 263 \\
\hline
\end{tabular}

FONTE: Informações Econômica (IEA), Horticultural Products Review (USDA)

A par disso, pode-se aferir a rapidez dessa evolução pela exportação de suco concentrado e congelado, que de 6.000 toneladas em 1963, subiu para 48.000 em 1970, atingiu 213.000 em 1977, e em 1988, 850.000 toneladas, proporcionando divisas no valor de 1,2 bilhão de dólares para o país, alçando o suco de laranja como uma das principais commodities ${ }^{12}$ agricolas nacionais. Desta forma, o setor citrícola é hoje um dos mais importantes do país, apesar de uma certa vulnerabilidade - já que está quase que totalmente voltado para o mercado externo - e o Brasil, é não só o maior produtor mundial de suco de laranja, como também é o maior exportador.

\footnotetext{
12 O suco de laranja é uma commodity e como tal é um produto de primeira elaboração industrial. Sua competitividade depende mais do acesso à matéria-prima e menos de conhecimentos tecnológicos. Tem menos valor, portanto, que o produto final entregue ao consumidor. Esse caso mostra também o "pecado" dessa indústria. Não existe nenhuma marca brasileira dominando o mercado mundial de suco de laranja. Nenhuma empresa multinacional brasileira conquistou os mercados mundiais. 0 produto brasileiro faz a fama de outras marcas e dá lucro para companhias que pegam o suco concentrado, acrescentam água e outros componentes, embalam e distribuem pelo mundo todo.
} 
Quanto ao consumo interno de fruta fresca, sua evolução pode ser considerada normal, acompanhando a grosso modo o crescimento populacional. Hoje, verifica-se que o mercado interno é grande, mas também é pobre e concentrado. Entretanto, segundo DI GIORGI (1991), o Brasil è o maior consumidor de fruta "in natura" do mundo, com o mercado doméstico dimensionado em torno de $20 \%$ da produção brasileira.

Com relação às exportações de frutas frescas, vale ressaltar que estabilizaramse em torno de dois milhões de caixas por ano e, até hoje, o mercado interno de suco concentrado é considerado "residual"13, embora represente um consumo de 20 mil toneladas anuais, graças à inclusão do suco em refrigerantes e ao esforço de vendas nacionais cada vez mais aceitas no mercado.

No que diz respeito à estrutura fundiária, não há no Estado de São Paulo, um cadastro que especifique o número total de propriedades citrícolas com seus respectivos tamanhos. Contudo, pode-se observar que, apesar da maioria dos pomares ser composto por pequenos proprietários, também há pomares com aproximadamente 1 milhão de laranjeiras, em latifúndios de 4,5 mil hectares. Mais da metade dos produtores vive exclusivamente da laranja. Alguns controlam florada e pulverização por computadores, enquanto outros ainda dependem da família para carpir o pomar. Todavia, embora o perfil sócioeconômico do citricultor paulista seja heterogêneo, aceitase que ele seja, na média, um agricultor bem-sucedido que cresceu muito nos últimos anos.

${ }^{13}$ Suco de laranja é um produto típico de consumidor de alto nível, que é a minoria da população brasileira. De todo suco de laranja produzido em nosso país, só $3 \%$ abastecem o mercado interno; os outros $97 \%$ destinam-se à exportação. 


\section{ESTUDOS SOBRE MODELOS DE OFERTA PARA CULTURAS PERENES}

A seleção apresentada nesta „seção não é exaustiva. Revisa somente as pesquisas que têm contribuído com novas teorias e métodos para a literatura dos modelos de resposta de culturas perenes, e que sejam relevantes para este estudo.

O conhecido "teorema da teia de aranha", com várias elaborações e modificações, tem servido como referência para o desenvolvimento de modelos que se propõem a explicar os fenômenos cíclicos da agricultura. $O$ teorema é aplicado em situações onde o processo produtivo envolve uma defasagem de tempo entre a decisão inicial de plantio e a produção final.

O primeiro trabalho mais criterioso foi elaborado por FRENCH \& BRESSLER (1962). Neste estudo, os autores levantaram a hipótese de que havia uma tendência de variações cíclicas na produção e preço do limão, ou seja, as condições essenciais do "teorema da teia de aranha" seriam encontradas no "ciclo do limão". O modelo desenvolvido é uma composição em termos de novos plantios e remoção para determinar a área em produção, expressa basicamente como:

$$
B_{t}=B_{t-1}+N_{t-5}-R_{t-1}
$$

Onde:

$B_{t}=$ área em produção no tempo $\mathrm{t}$;

$B_{t-1}=$ área em produção no tempo $\mathrm{t}-1$; 


$$
N_{t-5}=\text { novas áreas plantadas no ano } \mathrm{t}-5 \text {, ou seja, área entrando em produção }
$$

no tempo t;

$$
R_{t-1}=\text { área removida no ano } \mathrm{t}-1
$$

Os novos plantios foram definidos utilizando a seguinte expressão:

$$
\frac{N_{t}}{B_{t-1}}=b_{0}+b_{1} \pi^{*} t-1
$$

Onde:

$$
\begin{aligned}
& N_{\boldsymbol{t}}=\text { área plantada no tempo } \mathrm{t} ; \\
& B_{t-1}=\text { área em produção no tempo } \mathrm{t}-1 ;
\end{aligned}
$$

$$
\pi^{*} t-1=\text { expectativa de lucro no longo prazo formulada com base no lucro }
$$
médio dos últimos cinco anos.

Por fim, a primeira equação é convertida em oferta de limão através de sua multiplicação pelo rendimento. A principal virtude do modelo, destacada pelos autores, é a sua capacidade de prever os turning points, isto é, as mudanças repentinas dos dados históricos.

Este tipo de representação, com modificações ou simplificações, foi posteriormente aplicado na análise de outras culturas nos Estados Unidos: maçã, pêra e "tung nuts", com relativo sucesso. 
No entanto, a maioria dos trabalhos nesse periodo foi direcionada para commodities tipicamente produzidas em regiōes tropicais - principalmente café, cacau e borracha. Estudos de BATEMAN (1965) e BEHRMAN (1968), em particular, propiciaram expressivos avanços na formulação de modelos de oferta para culturas perenes, com especial atenção às culturas de áreas tropicais. Bateman e, mais tarde, Behrman ofereceram as primeiras tentativas explícitas de incluir nos seus modelos a questão das expectativas adaptativas de Nerlove. Pressupondo que os produtores maximizam o valor presente dos lucros esperados com a produção de cacau, estimaram equações na forma reduzida onde a produção é função da própria produção defasada, dos preços de produtos substitutivos e das condições ambientais passadas.

Contudo, o principal desenvolvimento neste campo só apareceu alguns anos depois, produto do trabalho de FRENCH \& MATTHEWS (1971), que introduziram o modelo mais completo para estimar produção de culturas perenes. Este modelo é visto como um aperfeiçoamento do trabalho de FRENCH \& BRESSLER (1962) porque incorpora suposiçōes mais sofisticadas sobre o comportamento do produtor. Utilizandose da teoria das expectativas racionais, desenvolvidas por MUTH (1961), os autores especificaram duas relações separadas: Uma que reproduzia o nivel de árvores produtivas, subseqüentemente combinada com novos plantios e remoção para o ajustamento em direção ao nivel desejado. A outra relação foi empregada para explicar o rendimento em termos de variação na distribuição de idade das árvores, crescimento de produtividade e condições ambientais. Finalmente, mudanças no rendimento e no nivel de árvores produtivas foram então combinadas para explicar as variaçōes na produção. Entre outras conclusōes os autores destacam a dificuldade de operacionalização do modelo, pois séries de dados fundamentais à estimação das funçōes não são disponiveis. Assim, este trabalho tem servido como fundamento para a 
maioria dos ensaios subseqüentes, mas, com simplificações para facilitar estimaçōes dentro de estruturas empíricas mais restritas.

Seguindo outro referencial teórico, ALBISU \& BLANDFORD (1983) desenvolveram um método baseado na teoria do investimento e aplicaram empiricamente o modelo para mudanças na área total das cinco principais variedades de laranjas na Espanha. Os autores incorporaram a teoria do investimento à análise de oferta de cultura perenes considerando que a diferença entre a área com novos plantios e a área removida é o investimento líquido, ou seja, mudanças no estoque de capital. Portanto, a cada estação, o investimento líquido pôde ser determinado calculando-se a diferença na área total plantada, da seguinte forma:

$A_{t}-A_{t-1}=A_{t}^{p}-A_{t}^{r}$

Onde:

$A_{t}=$ área total plantada no tempo t;

$A_{t-1}=$ área total plantada no tempo t-1;

$A_{t}^{p}=$ área com novos plantios no tempo t.

$A_{t}^{r}=$ área removida no tempo t 
A área com novos plantios foi expressa de forma implícita como:

$$
A_{t}^{p}=f\left(\pi_{t}^{*}, \pi_{a t}^{*}, U_{t}\right)
$$

Onde:

$$
\begin{aligned}
& \pi_{t}^{*}=\text { expectativa de lucro com a cultura no tempo } \mathrm{t} ; \\
& \pi_{a t}^{*}=\text { expectativa de lucro com culturas alternativas no tempo } \mathrm{t} ;
\end{aligned}
$$

$U_{t}=$ capacidade de utilização dos fatores medida pela proporção da área com árvores em produção pela área total plantada.

A área removida foi expressa de forma implícita como:

$$
A_{t}^{r}=g\left(D_{t}\right)
$$

Onde:

$D_{t}=$ capacidade de "desutilização" dos fatores medida pela proporção da área com árvores velhas pela área total plantada.

MANOS \& PAPANAGIOTOU (1983), usando o critério de maximização do valor presente do lucro esperado sobre o horizonte de produção de árvores frutiferas (pêras, maçãs e pêssegos), discorrerram sobre critérios de substituição de pomares existentes na região central da Grécia, por outros preferiveis economicamente. 
FRENCH, KING \& MINAMI (1985) adicionaram os efeitos de mudanças na composição de idades das árvores dentro dos modelos de resposta de culturas perenes. Esta consideração adicional sobre os ciclos de produção capacitou a análise para inferências sobre produções potenciais futuras. Igualmente, HARTLEY et alii (1987) examinaram a oferta de borracha na Sri Lanka, onde as decisões de colheita, replantio e novos plantios foram consideradas separadamente, e KALAITZADONAKES (1990) desenvolveu uma completa análise de investimento e estruturas de decisões de plantios e de cultivos para diferentes variedades de citros no Estado americano da Flórida.

Com relação aos modelos de simulação, entre os trabalhos analisados, vale a pena destacar dois estudos. BARITELLE \& PRICE (1974) analisaram o mercado de maçã na região de Washington - EUA. Um modelo de simulação combinando oferta, demanda e variáveis ambientais aleatórias foi usado para examinar as conseqüências de diferentes políticas de mercado sobre o setor. Uma equação de oferta de maçã em Washington foi estimada relacionando rendimentos com número de árvores por grupo de idade. O modelo primeiramente determinou a produção através da multiplicação do rendimento - gerado aleatoriamente - pelo número de árvores por idade. Então, políticas alternativas de mercado (políticas e equalização dos preços e políticas monopolísticas) determinaram o montante da produção que iria para consumo in natura e processamento. Usando relações de demanda estimadas por outros autores, os preços foram estabelecidos. As médias dos preços para os produtores foram calculadas e usadas na equação que gera novos plantios de árvores. O maior beneficio desse tipo de modelo, destacado pelos autores, é a sua habilidade em sinalizar sobre implicações futuras de políticas alternativas.

Para finalizar, McCLAIN (1989) utilizou a técnica de simulação Monte Carlo para modelar o mercado mundial de suco concentrado e congelado de laranja e projetar 
niveis médios de longo prazo de preços, produção e comércio. Um modelo estocástico e dinâmico foi usado para determinar a produção de laranja e a oferta de suco concentrado de laranja. As ofertas regionais determinadas para cada ano basearam-se no estoque de árvores distribuidaș pelas idades e seus respectivos rendimentos. Os efeitos estocásticos, medidos através de variações no rendimento cultural e na taxa de mortalidade, foram modelados indiretamente pela construção de distribuições probabilisticas, expressando a cada projeção, um diferente conjunto aleatoriamente selecionado para determinar estoque e produção final de árvores para cada periodo. Aproximações ad hoc das equações de demanda foram desenvolvidas em função das fracassadas tentativas em estimar empiricamente as demandas regionais. $\mathrm{O}$ modelo de simulação foi recursivamente resolvido para periodos futuros, igualando oferta total com demanda total de suco concentrado de laranja para determinar o preço mundial de equilibrio. Este preço foi usado para derivar os preços aos produtores em cada região, os quais influenciavam novos plantios e conseqüentemente produções futuras.

No Brasil, os estudos existentes que analisam a oferta de produtos agricolas limitaram-se, na sua maioria, à utilização do modelo nerloviano de retardamentos distribuidos. Uma amostra dos trabalhos que tratam desse assunto pode ser encontrada em SAYLOR (1973), FERREIRA (1974), LADEIRA (1974) e BASSO (1981).

Entre os trabalhos que apresentam estudos econométricos do mercado de laranja no Brasil, destacam-se NAMEKATA (1977) e NORONHA, GASQUES \& AMARO (1978).

Para a identificação dos fatores que influem na oferta de citros em São Paulo, no periodo 1948-75, NAMEKATA (1977) utilizou-se do modelo nerloviano de retardamentos distribuidos nas formas logaritmicas. Para tanto, buscou determinar as variáveis que afetavam a área colhida e o rendimento médio anual da cultura, através da análise 
comparativa dos parâmetros estimados de diferentes modelos. Com o objetivo de melhorar a especificação, o autor estimou equações utilizando modelos alternativos (modelos de oferta irreversiveis e modelos com equações simultâneas). Os resultados indicaram a ocorrência de defasagem de três anos na resposta de área e de rendimento às variações dos preços de fertilizantes e de citros, como o periodo necessário para que os novos plantios e as culturas existentes respondam aos estímulos de preços. Ou seja, verificou-se que a tomada de decisão do citricultor para fazer novos investimentos em citros resultava em aumentos na produçạo após três anos.

Já o trabalho apresentado por NORONHA et alii (1978) elabora um modelo para reproduzir o funcionamento do mercado de laranja in natura na capital de São Paulo, tomando-se como referência para a análise o periodo 1970-75. Os objetivos deste trabalho consistiam em determinar as principais variáveis econômicas influenciadoras do mercado, bem como verificar até que ponto a existência de outras frutas, em diferentes épocas do ano, afetava a demanda por laranja. Para isso, modelos alternativos de equações simultâneas constituidas de oferta e demanda foram estimados. Numa segunda etapa, uma vez caracterizada a dificuldade de usar o modelo de equações simultâneas, modelos de equação única de demanda foram estimados, para três diferentes periodos do ano, com o intuito de estudar efeitos de sazonalidade no consumo da fruta, relacionada com outras frutas. Como conclusão, essa pesquisa ressalta a inelasticidade renda e preço da demanda da laranja em São Paulo e as baixas elasticidades cruzadas da demanda da laranja em relação aos preços da maçã e da banana, ou seja, baixo efeito de substituição entre estas frutas. 


\section{MATERIAL E MÉTODO}

\subsection{INFORMAÇÃO BÁSICA}

As informações básicas utilizadas no presente estudo para derivar os vários parâmetros e componentes do modelo de simulação, são dados secundários publicados pelas várias agências governamentais, principalmente, pelo Instituto de Economia Agricola -IEA, Carteira de Comércio Exterior - CACEX e Instituto Brasileiro de Geografia e Estatisticas - IBGE.

A segunda fonte de informações refere-se a dados elaborados pelas associações do setor - ABRASSUCOS (Associação Brasileira das Indústrias de Sucos Cítricos), ABECITRUS (Associação Brasileira dos Exportadores de Cítricos) e a ACIESP (Associação dos Citricultores do Estado de São Paulo).

Considera-se, como fontes auxiliares, os estudos da área nos últimos 20 anos. Resultados relevantes daqueles autores sobre as variáveis do presente modelo serāo usados na comparação das estimativas encontradas. Tal fato visa corrigir possiveis viéses em decorrência das dificuldades de obtenção de dados fidedignos necessários para 0 ajuste daś funções. 


\subsection{O MODELO MATEMÁTICO}

O primeiro grande desafio no processo de qualquer modelagem está relacionado à clareza do problema analisado. Superada essa fase, outra grande dificuldade é a de identificar o melhor método de solução para o problema. O pesquisador deve considerar o mais adequado entre a série de alternativas de que dispõe.

As constantes e repentinas mudanças no mercado mundial de laranja, destacadas anteriormente, sugerem que as técnicas de programação podem ser mais úteis para entender esse mercado, quando comparadas aos modelos que usam técnicas exclusivamente econométricas. Nesta visão, um modelo de simulação pode ser mais apropriado para analisar o mercado citricola ao longo do tempo.

A simulação tem sido, tradicionalmente, uma das aplicações mais comuns de computadores, envolvẹndo a construção de modelos na forma de "programas".

Os modelos de simulação são expressões matemáticas que reproduzem as relações que definem o sistema e fornecem flexibilidade necessária para analisar os efeitos de mudanças nos parâmetros.

Há dois tipos de simulação que se diferenciam pelo intervalo de tempo para o qual são calculados os valores para as variáveis endógenas. No primeiro deles, simula-se o sistema completo ao longo de todo o periodo para o qual foi estimado. É a chamada simulação histórica. Supondo que o periodo de estimação vá de $t_{1}$ a $t_{n}$, os valores históricos do ano $t_{1}$ são fornecidos como condições iniciais para as variáveis endógenas, e as séries históricas, começando em $t_{1}$ até $t_{n}$, são usadas para as variáveis exógenas. 
Após o ano $t_{1}$, valores para as variáveis endógenas são determinados pela solução do processo de simulação.

Para se efetuar inferências, é necessário que a estrutura proposta represente o mundo real da melhor forma possivel. Para tanto, é de fundamental importância que a estrutura matemática do modelo seja verificada e validada a partir dos resultados gerados.

Assim, ao se simular o modelo durante o período para o qual valores históricos para todas as variáveis são disponiveis, uma comparação das séries históricas originais com as séries simuladas para cada variável endógena estabelece um bom teste para a validade da modelagem. Através desta comparação, pode-se avaliar a capacidade do modelo de reproduzir a realidade que ele representa. Este tipo de simulação também pode ser útil para analisar os efeitos de mudanças nas variáveis exógenas. Ao permitir que variáveis exógenas assumam novos valores, pode-se examinar e comparar o que teria acontecido como resultado de políticas alternativas.

O outro tipo de simulação chama-se previsão. Isto ocorre quando se calculam valores das variáveis endógenas para datas que avançam além do período para o qual as equações foram estimadas. Neste caso, não se tem meios de avaliar os resultados por comparação com dados históricos.

No presente estudo, considera-se a implementação do modelo através de um programa desenvolvido em linguagem CLIPPER 5.01, tendo em vista sua utilização em microcomputadores IBM/AT compativeis.

Para se estudar os objetivos sublinhados anteriormente, a metodologia combina oferta, demanda e suas variáveis componentes em um modelo de simulação histórica, 
com o intuito de projetar dinamicamente o mercado paulista de laranja sobre um horizonte de dezessete anos (1970 a 1987). A simulação consiste em, de posse dos valores das variáveis exógenas, encontrar, através de métodos iterativos, os valores das variáveis endógenas que satisfazem a todas as equações e identidades do modelo. Sua validação é feita simulando-o no período 1970-1987, para o qual existem dados históricos para todas as variáveis e comparando-se os valores simulados das variáveis endógenas com a série de dados originais.

A orientação do modelo é agregativa, isto é, ele tenciona explicar o comportamento dos produtores como um grupo, iniciando com certas pressuposições sobre o comportamento do produtor individual. Assume-se que os produtores estão sujeitos a preços comuns de produtos e fatores, possuem a mesma função de produção, e tentam maximizar o lucro.

O modelo envolve três principais componentes: (1) um sistema que determina a produção total de laranja. Esse sistema explica ano a ano as mudanças no número de árvores. A produção total de laranja em cada periodo é determinada pela multiplicação entre o número de ánores agrupadas em idades por seu respectivo rendimento; (2) um conjunto de equações que especificam a demanda total por laranja; e (3) uma equação de identidade entre oferta e demanda.

A formulação teórica baseia-se numa adaptação dos modelos de simulação para culturas perenes propostos por Baritelle (1974) e McClain (1989).

O sistema que determina a produção total de laranja pode ser expresso, em notação matricial, basicamente como: 


$$
Q_{t}=\left(\mathbf{A} \mathbf{X}_{t-1}+\mathbf{B} \mathbf{U}_{t}\right)^{\prime} \mathbf{Y}_{t}
$$

Onde:

$$
Q_{t}=\text { quantidade total de caixas de laranja produzidas no tempo t; }
$$

$\mathbf{A}=$ matriz (I,I) de taxa de sobrevivência. Descreve a proporção de árvores de cada grupo de idade que sobrevivem para o período posterior. Esta matriz é análoga a matriz de transição do modelo markoviano porque as taxas de sobrevivência são, neste sentido, probabilidades de transição. Como as árvores em cada grupo de idade ou sobrevivem para o próximo ano ou morrem, a maioria dos elementos da matriz $\mathbf{A}$ é zero, com, $0<a_{i}, i-1<1,0$. Por exemplo, $a_{54}$ é a proporção das árvores com idade 4 que sobrevivem, passando para a idade 5 .

$$
\mathbf{A}=\left|\begin{array}{cccccccc}
0 & 0 & 0 & 0 & 0 & \ldots & 0 & 0 \\
a_{21} & 0 & 0 & 0 & 0 & \cdots & 0 & 0 \\
0 & a_{32} & 0 & 0 & 0 & \cdots & 0 & 0 \\
0 & 0 & a_{43} & 0 & 0 & \cdots & 0 & 0 \\
0 & 0 & 0 & a_{54} & 0 & \cdots & 0 & 0 \\
0 & 0 & 0 & 0 & a_{65} & \cdots & 0 & 0 \\
. & . & . & . & . & \cdots & . & . \\
0 & 0 & 0 & 0 & 0 & \cdots & a_{I, I-1} & a_{I, I}
\end{array}\right|
$$

A linha I tem mais do que um elemento diferente de zero porque o último grupo inclui todas as árvores com idades maiores ou iguais a um valor selecionado. $\mathrm{Na}$ determinação deste último coeficiente leva-se em consideração a remoção de árvores consideradas antieconômicas.

$\mathbf{X}_{t-1}=$ vetor $(\mathrm{I}, 1)$ do número de árvores por idade no tempo t-1; 
$\mathbf{U}_{t}=$ vetor $(\mathrm{I}, 1)$ de ajustamento. Descreve o plantio de novas árvores no tempo $t$. Neste caso, $U_{11, t}$ é o primeiro e único elemento positivo do vetor. Todos os outros elementos são zeros;

$\mathbf{B}=$ matriz (I,I). Descreve os efeitos do ajustamento através do sistema, ou seja, a taxa de sobrevivência das novas árvores. Neste caso, $b_{11}$ é a taxa de sobrevivência para novos plantios. Todos os outros elementos são zeros;

$\mathbf{Y}_{t}=$ vetor $(\mathrm{I}, 1)$ de rendimento cultural por idade, em caixas/pé, no tempo t;

$\mathrm{i}=$ indice que indica $\mathrm{a}$ idade das árvores, $\mathrm{i}=0,1,2, \ldots, \mathrm{I}$. $\mathrm{O}$ último grupo de idade aplica-se para todas as árvores com idades maiores ou iguais a um valor selecionado;

$t=$ indice que indica o periodo de tempo, em anos; $t=1,2, \ldots, T$.

O rendimento cultural $\left(\mathbf{Y}_{t}\right)$ é primariamente uma função que pode variar através de decisões de cultivo no curto prazo e das condições ambientais no presente e no passado. Essas decisões, que incluem adubação, irrigação, controle de pragas e doenças, podem modificar significativamente o binômio rendimento-idade produtiva das árvores. Portanto,

$$
\mathbf{Y}_{\mathbf{t}}=Y\left(W_{t}, W_{t-1}, D_{t}\right)
$$

Onde:

$W_{t}=$ condições ambientais influenciando o rendimento no tempo t; 
$W_{t-1}=$ condições ambientais influenciando o rendimento no tempo t-1;

$D_{t}=$ variável representativa das decisões de cultivo no tempo t.

Conforme destacado no capitulo 3,0 crescimento no rendimento cultural, durante o periodo analisado, foi pequeno quando comparado ao crescimento da área plantada. Ou seja, os investimentos feitos pelos agricultores devem ter sido maiores na ampliação da área do que na adoção de tecnologias intensivas. Devido à complexidade desta função, adota-se a seguinte pressuposição simplificadora:

$$
\mathbf{Y}_{t}=(1+r) \mathbf{Y}_{t-1}
$$

Onde:

$r=$ taxa anual do crescimento do rendimento, expressa de forma decimal, e considerada constante para os diferentes grupos de idade.

A taxa anual de crescimento do rendimento é determinada com base nos valores extremos do periodo utilizando-se a seguinte expressão:

$$
V_{n}=V_{0}(1+r)^{n}
$$

onde:

$V_{n}=$ valor de uma certa grandeza no final do periodo;

$V_{0}=$ valor de uma certa grandeza no início do periodo; 
$n=$ periodo de anos considerado;

$r=$ taxa anual de crescimento $(r=\phi / 100$, sendo $\phi$ a taxa percentual de crescimento).

Desde que as decisões básicas de produção são implementadas primariamente na forma de novas árvores plantadas, necessita-se de uma equação para explicar mudanças na quantidade total de árvores produtivas. Essa equação será denominada "equação de novos plantios".

A forma da equação que explica o plantio de novas árvores é derivada de suposições plausiveis sobre o sistema de decisão dos produtores. A suposição básica é que as principais variáveis que influenciam o plantio de novas árvores são relacionadas a fatores econômicos. $O$ processo de ajustamento pode ser expresso em termos gerais como:

$$
N_{t}=N\left(\pi_{t}^{e}, P C_{t-1}, V T_{t-1}, C R E D_{t-1}\right)
$$

Onde:

$$
N_{t}=\text { número de novas árvores plantadas no tempo t; }
$$

$\pi_{t}^{e}=$ expectativa de lucro para a cultura da laranja;

$P C_{t-1}=$ preço para culturas alternativas no tempo $t-1$. Utiliza-se o preço recebido pelos produtores de cana-de-açúcar, considerando que esta é a principal cultura concorrente da laranja, em termos de área, no Estado de São Paulo; 
$V T_{t-1}=$ variável representativa do preço da terra no tempo t-1;

$C R E D_{t-1}=$ variável representativa do crédito rural no tempo $t-1$. Devido à carência de informações específicas para o setor citrícola durante todo o periodo de interesse, utiliza-se dados de crédito rural, fornecidos pelo Banco Central do Brasil, referentes a financiamentos agrícolas concedidos a produtores e cooperativas, ao nível do Estado de São Paulo.

As expectativas de lucro não podem ser observadas diretamente. Há, portanto, necessidade de assumir relações entre expectativas e algumas variáveis observadas, ou seja, formular hipóteses que relacionem as expectativas com variáveis que possam ser medidas. Há muitas hipóteses com respeito à forma como as expectativas de lucro são formadas e sua relação com valores observados. O lucro esperado pode ser função de preços esperados, rendimentos e custos. Desde que a laranja é produzida no Estado de São Paulo sob condições ambientais e físicas relativamente homogêneas, é conveniente acreditar que os produtores formulem suas expectativas de lucro baseando-se na média de preços para anos recentes. Por isso, adotar-se-á o mecanismo da média aritmética móvel para o preço recebido pelo produtor.

Com essas considerações, o termo de lucro esperado na equação (3) será representado pela média aritmética móvel do preço da caixa de laranja recebido pelo produtor $(P M)$. A introdução desta variável justifica-se pelo fato de ser a produção de laranja uma cultura permanente e que, portanto, o preço em um dado período de tempo não deve ser a única variável importante na decisão do agricultor, mas sim um preço que se poderia chamar de longo prazo (BARBOSA e SANTIAGO, 1988). 


$$
P M_{t}=\sum_{i=1}^{n} \lambda_{i} P L_{t-i}
$$

Onde:

$P M_{t}=$ média aritmética móvel, com $n$ termos, do preço da caixa de laranja recebido pelo produtor no tempo $\mathrm{t}$;

$$
P L_{t}=\text { preço em dólares da caixa de laranja recebido pelo produtor no tempo t. }
$$

Análises anteriores (McClain, 1989) sugerem que a relação de novos plantios poderia ser aproximada por uma função linear, formulada como:

$$
N_{t}=\beta_{0}+\beta_{1} P M_{t}+\beta_{2} P C_{t-1}+\beta_{3} V T_{t-1}+\beta_{4} C R E D_{t-1}+\eta_{t}
$$

Onde:

$$
\eta_{t}=\text { erro aleatório. }
$$

Os novos plantios tornam-se o primeiro elemento no vetor de ajustamento $\mathbf{U}_{\boldsymbol{t}}$ na equação (1), isto é,

$$
N_{t}=U_{11, t}
$$

Espera-se que o sinal do coeficiente da variável $P M$ seja positivo. Já o sinal do coeficiente $\beta_{2}$, referente ao preço recebido pelo produtor de cana-de-açúcar, deve ser negativo, na medida em que esta cultura concorre com a laranja em área. Considerando- 
se que a fronteira agricola, no Estado de São Paulo, está praticamente esgotada (MARTIN, 1981), a expansão da área cultivada com algumas culturas se daria necessariamente às custas da redução da área cultivada com outras culturas. Neste sentido, a rentabilidade relativa entre as culturas assume papel preponderante na determinação da composição da produção.

No que concerne ao valor da terra, deve-se esperar uma relação negativa entre esta variável e o número de novas árvores plantadas em função do maior preço da terra estar associado a maiores custos de produção.

Para o coeficiente da variável de crédito, espera-se um valor positivo, na medida em que os agricultores respondem com acréscimo de produção a estímulos creditícios.

O segundo conjunto de equações consiste em equações de demanda. Usando especificações sugeridas pela teoria econômica, a demanda interna por laranja pela indústria pode ser expressa em termos implícitos como:

$$
D_{i t}=D\left(P L_{t}, P S L_{t-1}, C A I N S T_{t}, E S T_{t}\right)
$$

Onde:

$D_{i t}=$ quantidade interna demandada por laranja pela indústria no tempo $\mathrm{t}$;

$P S L_{t-1}=$ preço em dólares do suco de laranja recebido pela indústria no tempo t-1; 
$\left(\right.$ AINST' $_{\boldsymbol{t}}=$ capacidade instalada, ou seja, capacidade interna de esmagamento de laranja no tempo t;

$E S T_{t}=$ estoque de suco de laranja concentrado no tempo t;

Análises anteriores (McClain, 1989) sugerem que a equação para a demanda interna por laranja poderia ser aproximada por uma função linear, formulada como:

$$
D_{i t}=\sigma_{0}+\sigma_{1} P L_{t}+\sigma_{2} P S L_{t-1}+\sigma_{3} \text { CAINST }_{t}+\sigma_{4} E S T_{t}+\varepsilon_{t}
$$

Onde:

$$
\varepsilon_{t}=\text { erro aleatório. }
$$

Espera-se que o coeficiente do $P L$ seja negativo, pois a quantidade varia em sentido contrário à variação do preço. Já para o PSL, o coeficiente deve ser positivo, pois uma elevação no preço do suco incentiva à maior produção deste e, com isso, a maior demanda pela laranja.

Espera-se um sinal positivo para o coeficiente da capacidade instalada e um sinal negativo para o coeficiente do estoque de suco de laranja concentrado, pois a existência de estoque desestimula sua produção e conseqüentemente a demanda por laranja.

A demanda interna por laranja pelos consumidores $\left(D_{c t}\right)$ será considerada variável exógena ao modelo. 
A equação da demanda total é, então, expressa por:

$$
D_{t}=D_{i t}+D_{c t}
$$

Onde:

$I_{1}=$ quantidade total demandada por laranja no tempo $\mathrm{t}$.

A determinação do preço recebido pelo produtor reside na suposição de equilibrio no mercado interno de laranja, isto é, a quantidade ofertada é igualada à quantidade demandada para se encontrar o preço de equilíbrio recebido pelo agricultor, o qual influencia o plantio de novas árvores no próximo período.

$$
Q_{t}=D_{t}
$$

O modelo é, então, simulado de forma recursiva para dezessete anos de acordo com o diagrama geral apresentado na figura 1. São colocados em retângulos os dados externos ao sistema, que podem, eventualmente, ser alterados. As setas mostram os fluxos dos dados, alguns dos quais são gerados e utilizados pelo próprio sistema. 


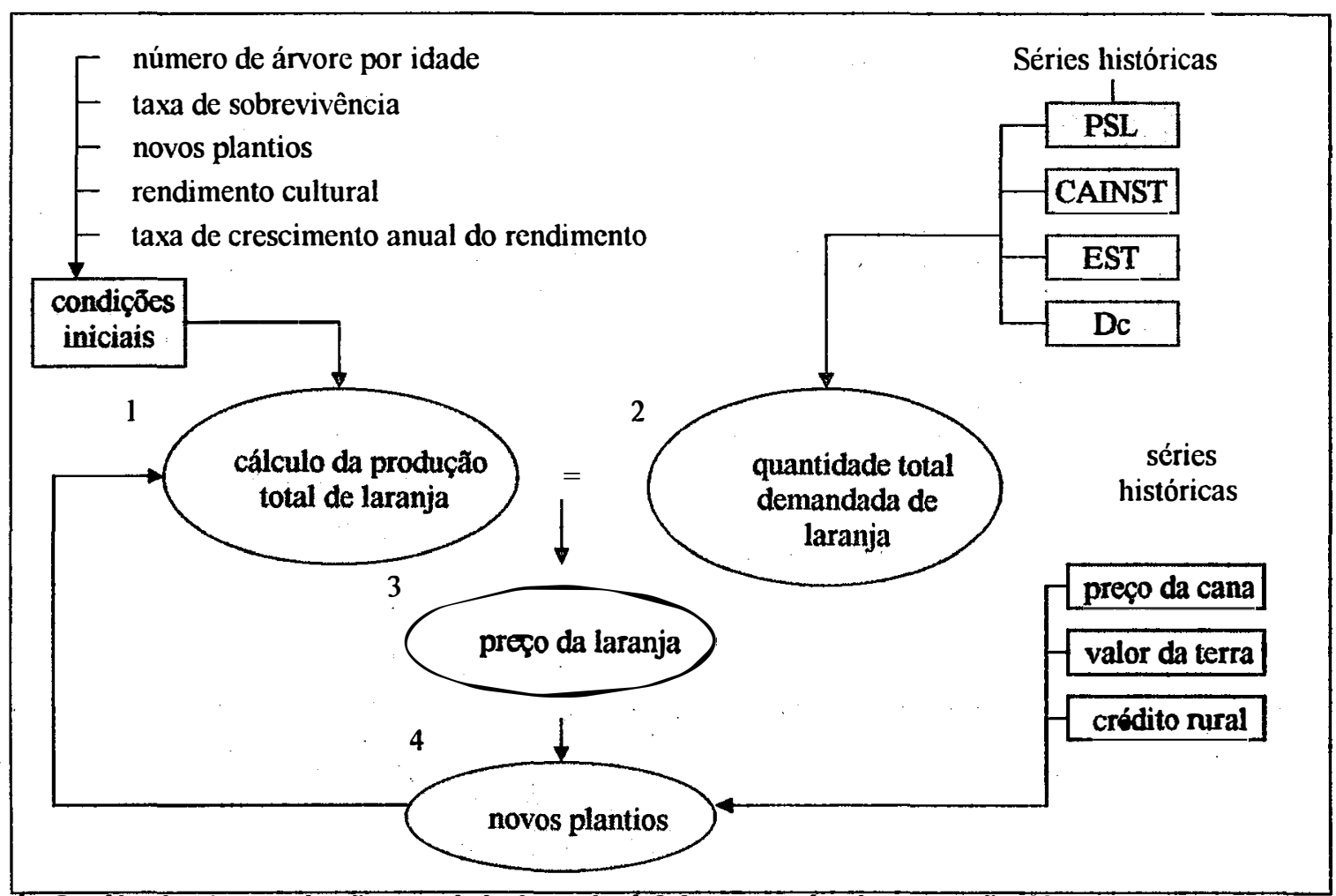

1. O cálculo da produção total de laranja é feito através da equação (1).

2. A quantidade total demandada de laranja é obtida a partir da equação (9).

3. $O$ preço da caixa de laranja recebido pelo produtor é calculado em função do equilibrio de mercado pela equação (10).

4. $O$ preço da caixa de laranja recebido pelo produtor permite o cálculo para os novos plantios, através da equação (5), que correspondem ao primeiro elemento do vetor de ajustamento na equação (1).

\section{FIGURA 1: Diagrama geral do processo de Simulação}

Com relação ao ajuste das equações do modelo aos dados das séries temporais, utiliza-se o método de estimação de Mínimos Quadrados Ordinários (MQO). Admite-se que os termos de resíduos ou erros $-\eta_{t}$ e $\varepsilon_{t}$, seguem as propriedades tradicionais, isto é, a média é nula, a variância residual é constante e os erros são não-correlacionados e tem distribuição normal. 
Como é pouco provável que a seqüência calculada durante o processo de simulação seja a realmente ocorrida, na avaliação do seu comportamento, apresenta-se a série dos dados históricos, a série calculada, a série de erros absolutos e percentuais para cada período. Tem-se:

$$
\begin{aligned}
& E R R O=\text { VALOR SIMULADO }- \text { VALOR HISTÓRICO } \\
& E R R O(\%)=100\left(\frac{E R R O}{\text { VALOR HISTÓRICO }}\right)
\end{aligned}
$$

Para verificar se os componentes internos do modelo interagem como desejado, expressando o comportamento real do mercado, avalia-se também sua capacidade em simular as mudanças repentinas dos dados históricos. De acordo com PINDYCK \& RUBINFELD (1981), apresentam-se, também, a média, o desvio padrão e a raiz média quadrática $(R M Q)^{14}$ de cada série, com:

$R M Q=\sqrt{\sum_{t}^{Z_{t}^{2}} / n}$

Onde:

$Z_{t}$ é a série considerada e $n$ o número de períodos da simulação.

Além disso, os mesmos testes usados para avaliar uma previsão feita com uma equação de regressão, podem ser utilizados na avaliação do comportamento da simulação.

${ }^{14}$ A raiz média quadrática apresenta limite inferior zero e valores tão mais próximos desse limite quanto menores forem os erros no processo de simulação. 
Seja $S_{t}$ a série simulada e $W_{t}$ a série histórica. Considerando o modelo $W_{t}=\psi+\mu S_{t}+\delta_{t}$, utiliza-se o teste de hipótese $\mathrm{H}_{0}: \psi=0$ e $\mu=1$, correspondente à situação em que a série simulada é igual à série histórica, contra $\mathrm{H}_{1}: \psi \neq 0$ e $\mu \neq 1$. Os

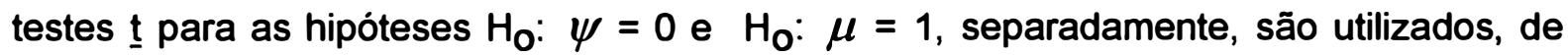
forma complementar, na interpretação dos resultados. Adicionalmente, calcula-se $\circ \bar{R}^{2}$ da regressão e faz-se uma análise de correlação entre as variáveis observadas e simuladas.

. Uma análise pormenorizada dos testes acimas descritos pode ser vista em KOST (1980).

Após a validação do modelo para o período 1970-87, encerra-se o trabalho com a tentativa de resolução do problema básico do estudo. Ou seja, a resposta à questãó central de até que ponto a política de crédito agrícola subsidiado pelo governo brasileiro foi um fator decisivo no desenvolvimento do setor citricola no Estado de São Paulo.

Para tal, o modelo final é simulado novamente, anulando-se a variável que representa o crédito agrícola subsidiado. Feito isto, compara-se o resultado destas novas simulações com as simulações originais, para só assim se concluir quanto ao impacto do crédito interno sobre o desempenho do setor. 


\section{RESULTADOS E DISCUSSÃO ${ }^{15}$}

\subsection{EQUAÇÃO DE NOVOS PLANTIOS}

A equação de novos plantios de árvores de laranja para o Estado de São Paulo foi estimada usando dados para o periodo de 1969 a 1989.

Muitas variáveis foram testadas na tentativa de estimar esta função, tais como preços defasados ou médias de preços defasados da caixa de laranja recebidos pelo produtor, preços defașados da tonelada de cana-de-açúcar recebidos pelo produtor, preços de venda da terra nua de primeira e de segunda, número total de árvores de laranja, preço da muda de laranja e crédito rural recebido pelos produtores e cooperativas.

De todas tentativas, considerando a proporção da variação "explicada" pela regressão $\left(\bar{R}^{2}\right)$ e a significância estatística dos coeficientes, o modelo selecionado que melhor representou os novos plantios foi uma função linear que incluiu a razão entre preço da caixa de laranja e o preço da tonelada de cana-de-açúcar defasados de um ano e o crédito rural:

$$
N_{t}=\beta_{0}+\beta_{1}\left(\frac{P L_{t-1}}{P C_{t-1}}\right)+\beta_{2} C R E D_{t-1}+\eta_{t}
$$

As estimativas resultantes, determinadas pelo método de minimos quadrados ordinários (MQO), são apresentadas na tabela 8.

\footnotetext{
${ }^{15}$ A lista de todos os dados utilizados no ajuste das funções do modelo, bem como das condições iniciais necessárias para o processo de simulação (vide figura 1), está detalhada no APÊNDICE 2.
} 
TABELA 8 - Estimativa dos parâmetros da equação de novos plantios de laranja 1969 a 1989.

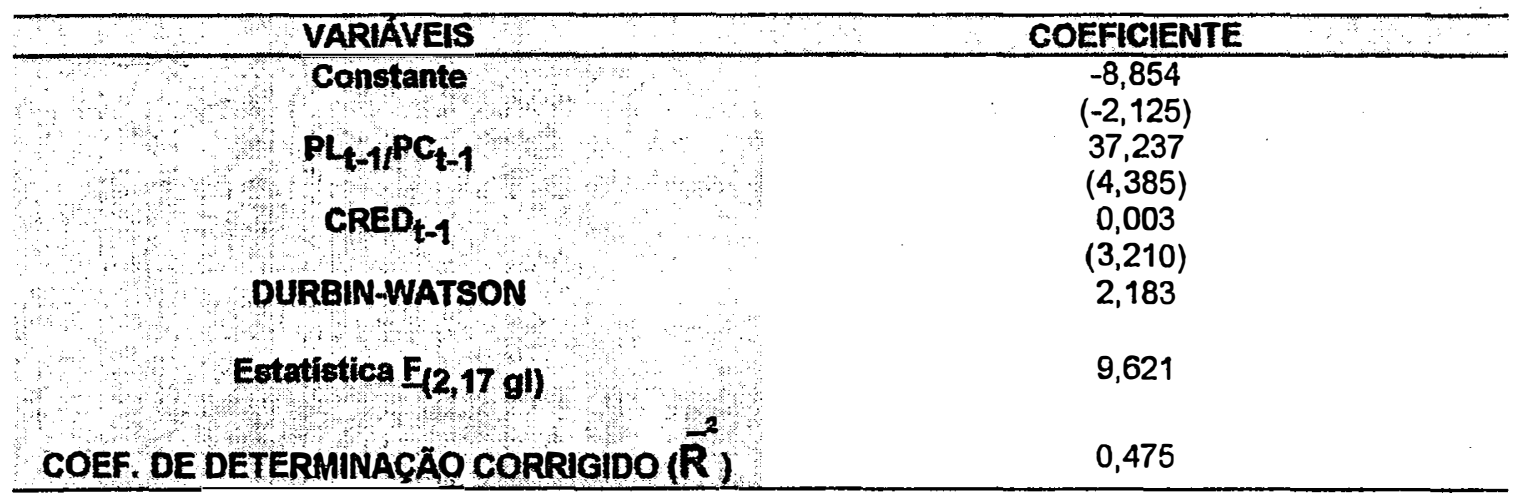

Obs: Os valores entre parênteses correspondem às estatísticas $t$ da distribuição de student.

De posse dos valores ajustados, os resultados econométricos mostraram-se satisfatórios $^{16}$. O teste $t$ de Student indica que os coeficientes são significativos ao nivel de $1 \%$ (exceto o termo constante que mostrou-se significativo ao nivel de $10 \%$ ). Quanto à estatística $\underline{F}$ de Snedecor, da ordem de 9,621 , os resultados atestam significância ao nivel de 0,01 de probabilidade.

No que concerne à expectativa de lucro (equação 4), os resultados mostraram-se mais satisfatórios quando considerou-se ponderação 1 (um) para o preço da caixa de laranja imediatamente anterior. Isto é, o preço defasado de um período é o que melhor exprimiu as expectativas de lucro dos produtores. Aparentemente, isso pode estar associado ao caráter imediatista do tomador de decisão, ou seja, o produtor sobrevaloriza o preço corrente, o curto prazo, sem maiores preocupações pelo planejamento da produção e o futuro comportamento de mercado.

A variável preço da terra foi excluida do modelo, uma vez que apresentou-se com coeficiente não-significativo. Uma investigação mais detalhada sugere uma explicação para esse resultado aparentemente incoerente, pois, ocorre que, de uma forma geral, os

\footnotetext{
${ }^{16}$ McLAIN (1989), pesquisando novos plantios para o Estado de São Paulo entre os anos de 1964 a 1985, encontrou o valor de apenas 0,379 para o coeficiente de determinação corrigido.
} 
produtores de laranja já dispõem de terra para expandir seus cultivos. Conseqüentemente, o preço da terra não está associado a maiores custos de produção.

$\mathrm{Na}$ figura 2 a série histórica de novos plantios e a série prevista pela função estimada, expressas em milhões de pés/ano, são apresentadas.

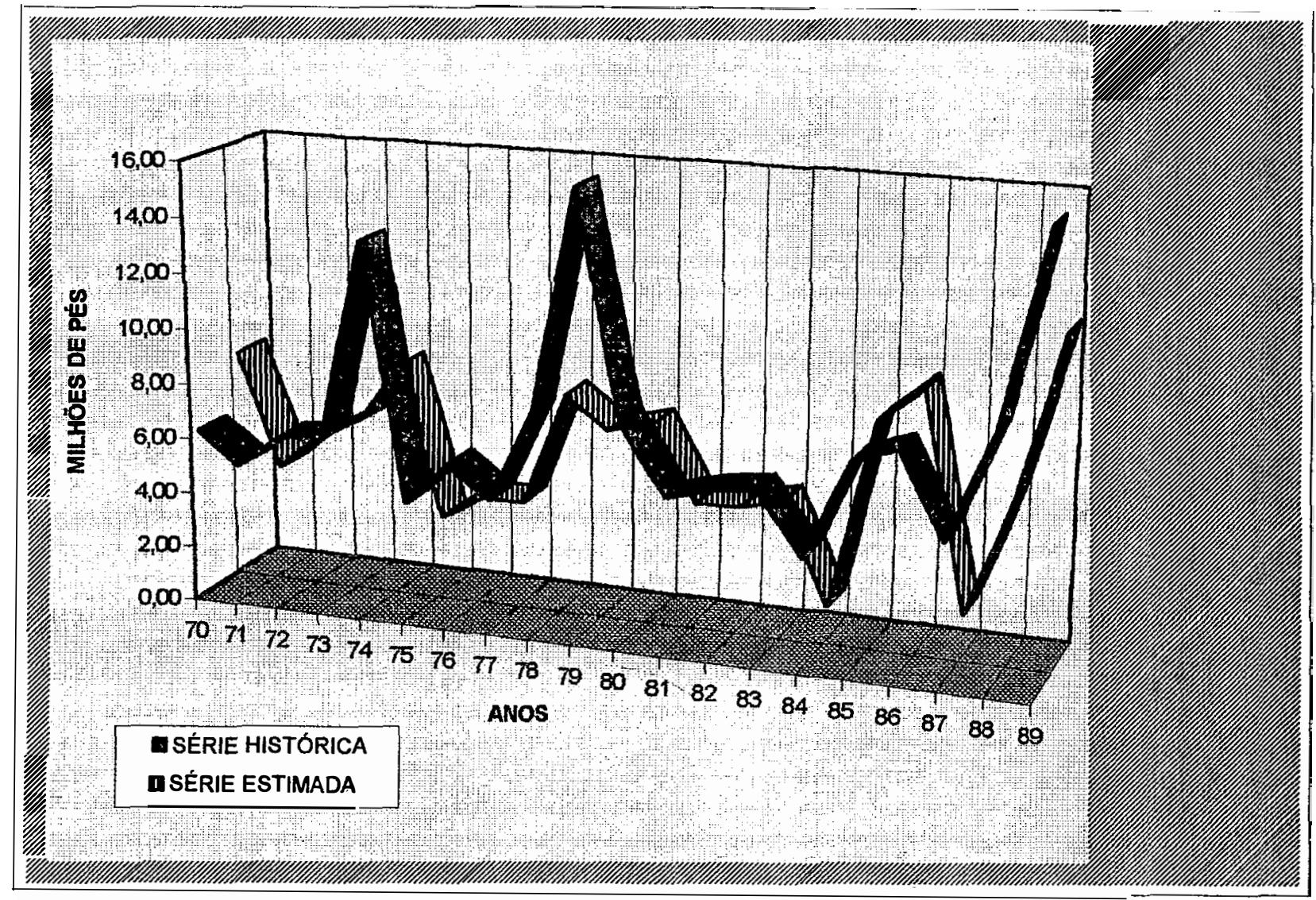

FIGURA 2 - SÃO PAULO: série histórica e série estimada de novos plantios, expressas em milhões de pés/ano, $1970 / 89$. 


\subsection{EQUAÇÃO DE DEMANDA POR LARANJA PELA INDÚSTRIA BRASILEIRA}

A tabela 9 apresenta os resultados do ajustamento linear da equação de demanda por laranja pela indústria brasileira (equação 8).

TABELA 9: Estimativa dos parâmetros da equação de demanda por laranja pela indústria brasileira- 1968 a 1987.

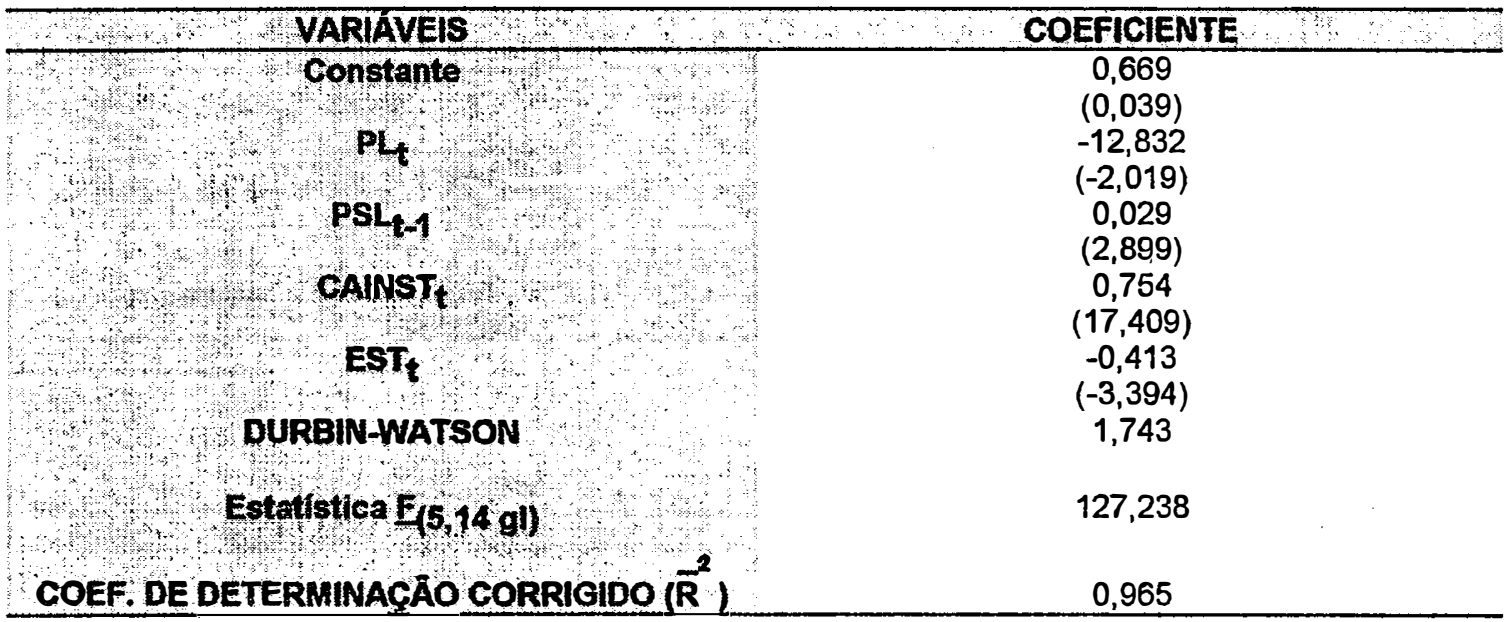

Obs: Os valores entre parênteses correspondem às estatísticas $t$ da distribuiçāo de student.

Na estimativa da equação de demanda por laranja pela indústria brasileira, verificou-se que o valor da estatística $\underline{F}$ é altamente significante e o coeficiente de determinação corrigido mostrou-se acima de $96 \%$, podendo-se afirmar que as variáveis especificadas têm alto poder de explicação das variações na demanda por laranja. Quanto à estatistica de Durbin-Watson, os resultados atestam a inexistência de autocorrelação nos resíduos ao nível de $1 \%$.

De maneira geral, os coeficientes estimados apresentaram coerência de sinais, mostrando consistência com as hipóteses teóricas, isto é, a demanda interna por laranja pela indústria é diretamente relacionada com o preço do suco e a capacidade instalada, e inversamente relacionada com o preço da caixa de laranja e o estoque de suco. $\mathrm{O}$ teste $\mathrm{t}$ de Student indica que os coeficientes da capacidade instalada $(17,409)$ e do estoque de 
suco $(-3,394)$ são significantes ao nivel de $1 \%$ de probabilidade, enquanto os coeficientes para a variável preço do suco e preço da caixa de laranja são significativos, respectivamente, ao nivel de $5 \%$ e $10 \%$.

É interessante notar a importância da capacidade instalada para esta equação, em função da sua elevada significância. Além disso, os resultados sugerem que no período estudado, o preço internacional do suco de laranja foi mais significativo para a indústria do que o preço que esta paga aos produtores.

\subsection{RESULTADOS DA SIMULAÇÃO DO MODELO MATEMÁTICO}

\subsubsection{VALIDAÇÃO DO MODELO}

O modelo de simulação que consiste em, de posse dos valores das variáveis exógenas, encontrar os valores das variáveis endógenas foi primeiramente desenvolvido para reproduzir o mercado paulista de laranja. Tendo em vista os objetivos principais do trabalho, tomou-se por base para a simulação o periodo de 1970 a 1987, considerado satisfatório, haja visto a aceleração do crescimento do setor no período, bem como a maior atuação da política de crédito rural do governo brasileiro.

A validação do modelo é feita simulando-o neste periodo e comparando-se os valores simulados das variáveis endógenas com a série de dados originais. Seu propósito é fomecer provas quanto à habilidade do modelo em gerar informações coerentes com a realidade. 
Tomando-se por base os plantios realizados anualmente (tabela 6) e considerando-se que havia, em 1969, aproximadamente 32,8 milhões de pés de laranjas plantados, dos quais, segundo o IEA, 6,8 milhōes de pés novos com menos de 3 anos de idade, foi possivel estimar de modo preliminar a distribuição etária das árvores de laranja como segue:

Pés com 0 a 3 anos...

$42 \%$

Pés com 4 a 7 anos.

$21 \%$

Pés com 8 a 10 anos.

$24 \%$

Pés com pelo menos 11 anos

$13 \%$

De outra parte, verifica-se que uma laranjeira, em pomares comerciais, começa a produzir de maneira expressiva aos 3 anos de idade, aumenta a produção até 10-12 anos, estabiliza a produção por alguns anos e começa a declinar. Dessa forma, optou-se pela distribuição das árvores em grupo de idade de até 25 anos.

Além disso, a partir de valores atuais de rendimentos médios das plantas de laranja de acordo com a faixa etária (AMARO, 1980 e MCCLAIN, 1989), e considerandose uma taxa anual de crescimento da produtividade de $0,3 \%$ (calculada utilizando-se a equação 2a), os seguintes rendimentos médios foram calculados para o ano de 1969:

Pés com 0 a 3 anos

0,16 caixas/pé

Pés com 4 a 7 anos

1,56 caixas/pé

Pés com 8 a 10 anos.

2,55 caixas/pé

Pés com pelo menos 11 anos.

1,65 caixas/pé 
Quanto à taxa de sobrevivência das árvores, a tabela 10 apresenta os valores usados na simulação:

TABELA 10 - BRASIL: distribuição da taxa de sobrevivência das árvores de laranja por idade.

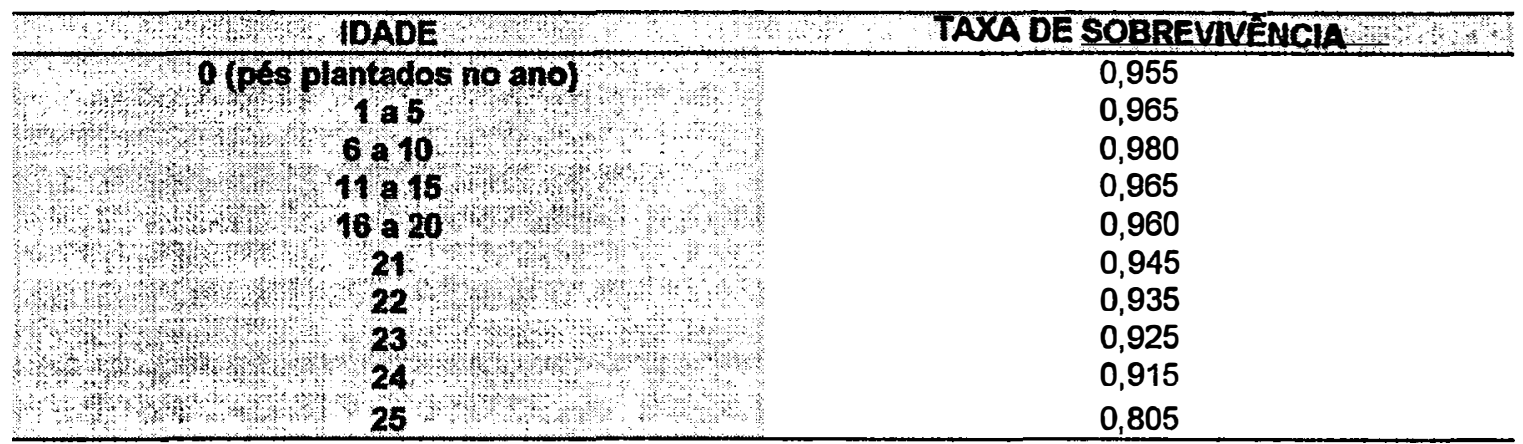

FONTE: McClain (1989)

Os resultados do modelo básico para cada variável endógena são apresentados nas tabelas $11,12,13$, e 14, bem como nas figuras correspondentes. Em cada tabela aparece a série de valores históricos e simulados, a série de erros absolutos e percentuais, e os respectivos, desvio padrão, raiz média quadrática e média aritmética.

A tabela 15 mostra as estimativas da regressão linear dos valores observados em função dos valores simulados. Nela, apresentam-se os resultados dos testes aplicados a fim de se verificar a validade do modelo.

Pode-se constatar pela tabela 11 e figura 3 que os resultados da simulação para a produção paulista de laranja são bastante satisfatórios, apresentando erros percentuais aceitáveis, com um valores máximos de 23,22\% e 25,79\% nos anos de 1974 e 1978, respectivamente anos de crises no setor associadas aos ajustamentos dos "choques" do petróleo. A proporção de aproximadamente 0,3 entre o número de erros positivos e negativos indica um viés para menos nos valores simulados, isto é, os valores simulados tendem a ser menores do que os valores históricos. Entretanto, os baixos resultados 
encontrados para a raiz média quadrática e para a média aritmética dos erros absolutos e percentuais sugerem não rejeitar as diferenças entre os valores hisțóricos e simulados. Há uma simulação satisfatória do comportamento da variável para o período. Mas, de acordo com a tabela 15, a hipótese de igualdade entre esses valores é rejeitada, pois, apresenta teste para $H_{0}: \psi=0$ e $\mu=1$ significativo a $1 \%$. Contudo, os teste $\underline{t}$ para as hipóteses $H_{0}: \psi=0$ e $H_{0}: \mu=1$, não-significantes ao nivel de $1 \%$, e o valor de $\bar{R}^{2}$ da ordem de $95,5 \%$ bastante significativo, apresentam-se como esperado.

TABELA 11 - Simulação da quantidade produzida de laranja no Estado de São Paulo, em milhões de caixas $(40,8 \mathrm{~kg})$ - 1970/87.

\begin{tabular}{|c|c|c|c|c|}
\hline ANO & $\begin{array}{l}\text { PRODUGAO } \\
\text { HISTÓRICA }\end{array}$ & $\begin{array}{l}\text { PRODUCAAO } \\
\text { SIMULABA }\end{array}$ & $\begin{array}{l}\text { ERRO } \\
\text { ABSOLUTO }\end{array}$ & $\begin{array}{l}\text { ERRO } \\
\text { PERCENUAL }\end{array}$ \\
\hline 1970 & 44,00 & 45,46 & 1,46 & 3,32 \\
\hline 1971 & 46,00 & 48,45 & 2,45 & 5,33 \\
\hline $1972 \mathrm{~W}$ & 61,00 & 51,71 & $-9,29$ & $-15,23$ \\
\hline 1873 & 62,00 & 56,55 & $-5,45$ & $-8,79$ \\
\hline 1974 W & 82,00 & 62,96 & $-19,04$ & $-23,22$ \\
\hline 1975 a & 85,00 & 71,84 & $-13,16$ & $-15,48$ \\
\hline 1976 & 100,00 & 84,47 & $-15,53$ & $-15,53$ \\
\hline 1977 . & 92,00 & 98,04 & 6,04 & 6,57 \\
\hline $1978 \ldots$ & 150,00 & 111,32 & $-38,68$ & $-25,79$ \\
\hline 1979.4$)$ & 155,00 & 125,04 & $-29,96$ & $-19,33$ \\
\hline 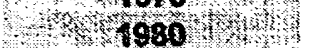 & 170,00 & 139,40 & $-30,60$ & $-18,00$ \\
\hline Wh & 180,00 & 155,37 & $-24,63$ & $-13,68$ \\
\hline Hot & 195,00 & 169,60 & $-25,40$ & $-13,03$ \\
\hline 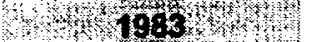 & 200,00 & 184,24 & $-15,76$ & $-7,88$ \\
\hline 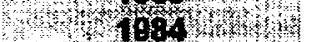 & 205,00 & 196,59 & $-8,41$ & $-4,10$ \\
\hline 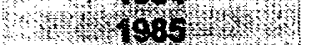 & 239,00 & 206,14 & $-32,86$ & $-13,75$ \\
\hline 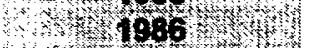 & 220,00 & 211,29 & $-8,71$ & $-3,96$ \\
\hline 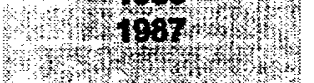 & 210,00 & 218,37 & 8,37 & 3,99 \\
\hline $\begin{array}{l}\text { OESVIO } \\
\text { WADRAO }\end{array}$ & 64,73 & 60,54 & 13,61 & 9,60 \\
\hline 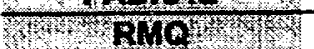 & 153,02 & 138,23 & 19,81 & 13,80 \\
\hline MEDIA & 138,67 & 124,27 & $-14,40$ & $-9,92$ \\
\hline
\end{tabular}




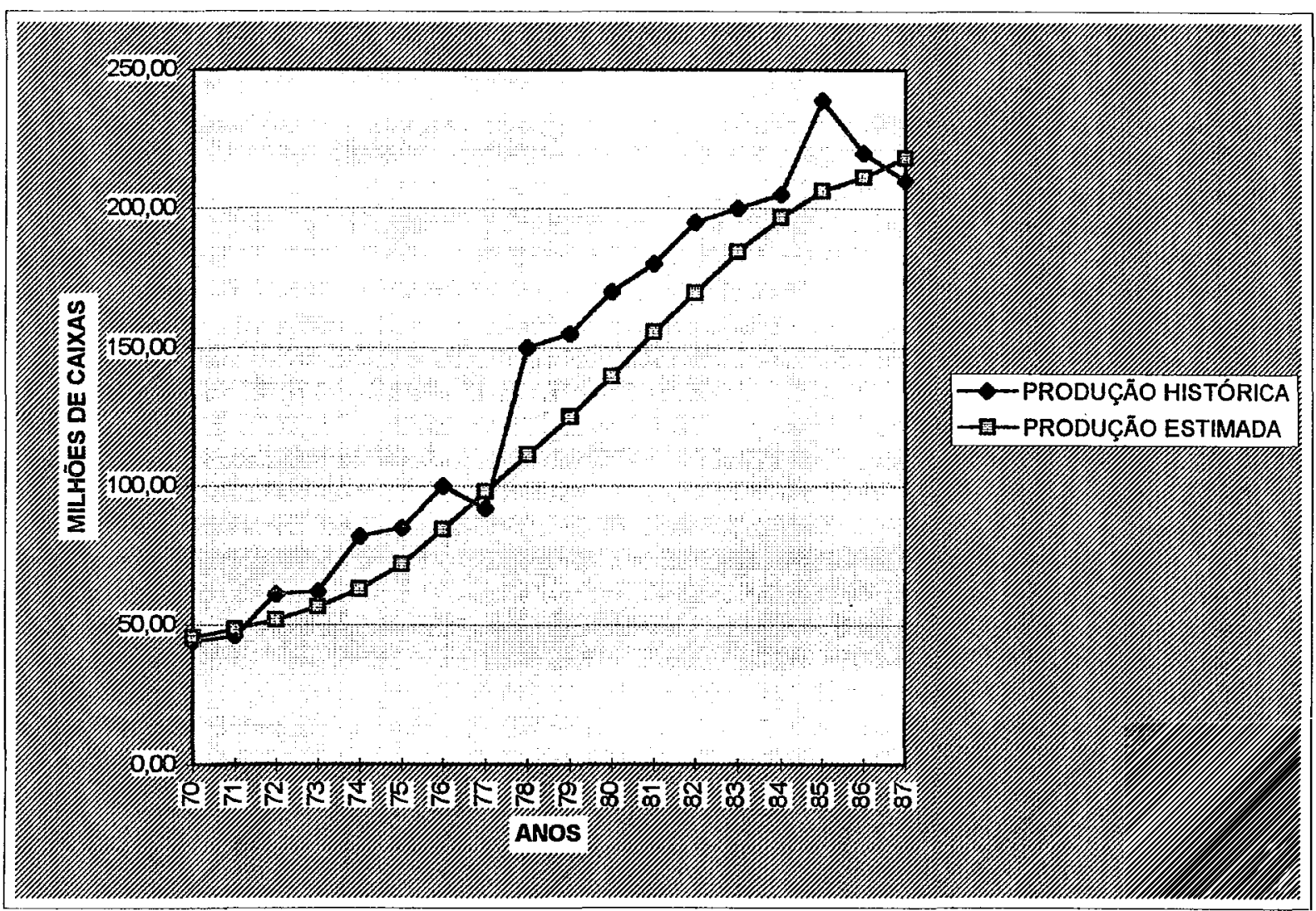

FIGURA 3 - SÃO PAULO: produção histórica e produção simulada de laranja, em milhões de caixas $(40,8 \mathrm{~kg}), 1970 / 87$.

Para a variável de demanda por laranja pela indústria brasileira, de um modo geral, o modelo também foi eficiente para reproduzir os valores históricos, como representado pela tabela 12 e pela figura 4 . 
TABELA 12: Simulação da demanda por laranja pela indústria brasileira, milhões de caixas $(40,8 \mathrm{~kg})-1970 / 87$.

\begin{tabular}{|c|c|c|c|c|}
\hline ANO & $\begin{array}{l}\text { DEMANDA } \\
\text { HISTÓRICA }\end{array}$ & $\begin{array}{l}\text { DEMANDA } \\
\text { SIMULADA }\end{array}$ & $\begin{array}{l}\text { ERRO } \\
\text { ABSOLUTO }\end{array}$ & $\begin{array}{l}\text { ERRO } \\
\text { PERCENTUAL } \\
\end{array}$ \\
\hline 1970 & 15,00 & 27,29 & 12,29 & 81,93 \\
\hline 1971 & 25,00 & 29,37 & 4,37 & 17,48 \\
\hline 1972 & 34,30 & 28,82 & $-5,48$ & $-15,98$ \\
\hline 1973 & 39,60 & 33,54 & $-6,06$ & $-15,30$ \\
\hline 1974 & 55,10 & 32,14 & $-22,96$ & $-41,67$ \\
\hline 1975 & 52,00 & 42,38 & $-9,62$ & $-18,50$ \\
\hline wat & 69,00 & 56,80 & $-12,20$ & $-17,68$ \\
\hline 1977 & 60,00 & 61,57 & 1,57 & 2,62 \\
\hline 1978 & 117,00 & 94,42 & $-22,58$ & $-19,30$ \\
\hline 1979 & 124,00 & 114,95 & $-9,05$ & $-7,30$ \\
\hline 1980 & 138,00 & 129,39 & $-8,61$ & $-6,24$ \\
\hline $1981 \%$ & 155,00 & 136,47 & $-18,53$ & $-11,95$ \\
\hline W. & 161,00 & 145,69 & $-15,31$ & $-9,51$ \\
\hline 1983 & 165,00 & 156,17 & $-8,83$ & $-5,35$ \\
\hline 1984 & 185,00 & 186,55 & 1,55 & 0,84 \\
\hline 1985 & 220,00 & 196,14 & $-23,86$ & $-10,85$ \\
\hline 1986 & 163,00 & 164,33 & 1,33 & 0,82 \\
\hline whos & 185,00 & 198,36 & 13,36 & 7,22 \\
\hline $\begin{array}{c}\text { DESVIO } \\
\text { PADRAO }\end{array}$ & 63,39 & 62,00 & 10,96 & 24,20 \\
\hline RHO & 126,13 & 119,28 & 13,08 & 24,49 \\
\hline MEDIA & 109,06 & 101,91 & $-7,15$ & $-3,82$ \\
\hline
\end{tabular}

Os resultados revelados nas simulações da demanda interna por laranja pela indústria brasileira são bastante relevantes. Apesar da tendência do modelo em simular valores abaixo dos históricos, os erros são estatisticamente insignificantes conforme pode-se constatar na tabela 15. O teste de $\mathrm{E}$ para a hipótese $H_{0}: \psi=0$ e $\mu=1$ mostrouse não-significante ao nivel de $5 \%$ de probabilidade. Com exceção dos erros percentuais encontrados para o ano de 1970 e 1974, os demais são aceitáveis. Esses erros podem ter sido influenciados pela ocorrência de pequenos estoques de suco nos anos respectivamente anteriores, bem como pela crise deflagrada através da falência da Sanderson SIA no ano de 1974. Associando-se esses resultados aos baixos valores encontrados para a raiz média quadrática e a média aritmética dos erros absolutos e percentuais, conclui-se quanto ao bom ajuste entre os valores históricose simulados. Esses resultados certamente foram influenciados pela especificação da equação da demanda por laranja pela indústria brasileira, que apresentou um $\bar{R}^{2}$ acima de $96 \%$. 


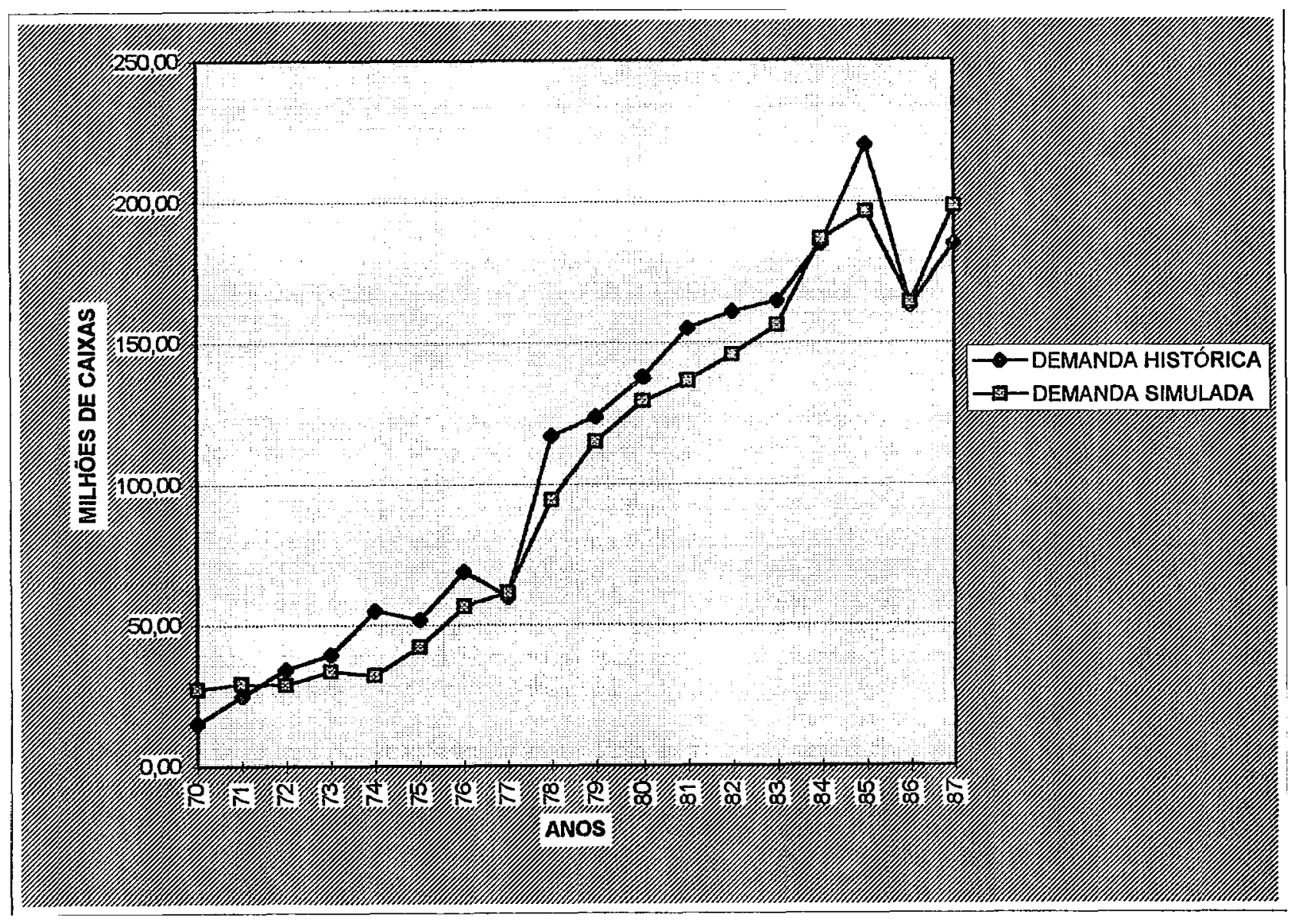

FIGURA 4 - Demanda histórica e demanda simulada por laranja pela indústria brasileira, milhões de caixas $(40,8 \mathrm{~kg}), 1970 / 87$. 
A tabela 13 e a figura 5 apresentam os resultados referentes à variável preço da caixa de laranja recebido pelo produtor.

TABELA 13 - Simulação do preço da caixa de laranja recebido pelo produtor em dólares, 1970/87.

\begin{tabular}{|c|c|c|c|c|}
\hline ANO & $\begin{array}{l}\text { PREÇO } \\
\text { HISTÓRICO }\end{array}$ & $\begin{array}{l}\text { PREÇO } \\
\text { SIMULADO }\end{array}$ & $\begin{array}{l}\text { ERRO } \\
\text { ABSOLUTO }\end{array}$ & $\begin{array}{l}\text { ERRO } \\
\text { PERCENTUAL }\end{array}$ \\
\hline 1970 & 2,14 & 2,42 & 0,28 & 13,08 \\
\hline $\begin{array}{r}1971 \\
\end{array}$ & 2,38 & 2,54 & 0,16 & 6,72 \\
\hline 1972 & 2,48 & 2,83 & 0,35 & 14,11 \\
\hline 1973 & 2,95 & 3,80 & 0,85 & 28,81 \\
\hline 1974 & 1,43 & 1,72 & 0,29 & 20,28 \\
\hline (3) & 1,54 & 2,26 & 0,72 & 46,75 \\
\hline 4 & 1,61 & 2,35 & 0,74 & 45,96 \\
\hline (w) & 3,04 & 2,84 & $-0,20$ & $-6,58$ \\
\hline Wit & 2,57 & 3,36 & 0,79 & 30,74 \\
\hline Wh & 2,28 & 3,35 & 1,07 & 46,93 \\
\hline कens & 1,60 & 3,23 & 1,63 & 101,87 \\
\hline Hen & 2,02 & 2,40 & 0,38 & $18 ; 81$ \\
\hline 1982 & 1,71 & 1,93 & 0,22 & 12,87 \\
\hline 1983 & 1,31 & 1,64 & 0,33 & 25,19 \\
\hline 1984 & 2,37 & 2,63 & 0,26 & 10,97 \\
\hline mo & 3,05 & 3,61 & 0,56 & 18,36 \\
\hline 1986 & 1,03 & 1,67 & 0,64 & 62,14 \\
\hline 1987 & 2,10 & 2,60 & 0,50 & 23,81 \\
\hline $\begin{array}{l}\text { DESVIO } \\
\text { PADRAO }\end{array}$ & 0,59 & 0,64 & 0,40 & 24,14 \\
\hline BStla RMO & 2,17 & 2,69 & 0,66 & 37,68 \\
\hline MEDIA & 2,09 & 2,62 & 0,53 & 28,94 \\
\hline
\end{tabular}

Comparando-se na figura 5 , os preços recebidos por caixa de laranja com os preços simulados, observa-se a capacidade do modelo em captar as mudanças repentinas dos preços. Contudo, apesar do valor de aproximadamente $37 \%$ para a raiz média quadrática do erro percentual ser considerado satisfatório, o teste $E$ para a hipótese $H_{0}: \psi=0$ e $\mu=1$ mostrou-se significativo ao nivel de $1 \%$ de probabilidade. Vale ressaltar que num mercado sujeito a constantes e repentinas mudanças, como é o de laranja, não é tarefa das mais simples elaborar uma modelagem que seja capaz de reproduzir com precisão o comportamento histórico dos preços. 


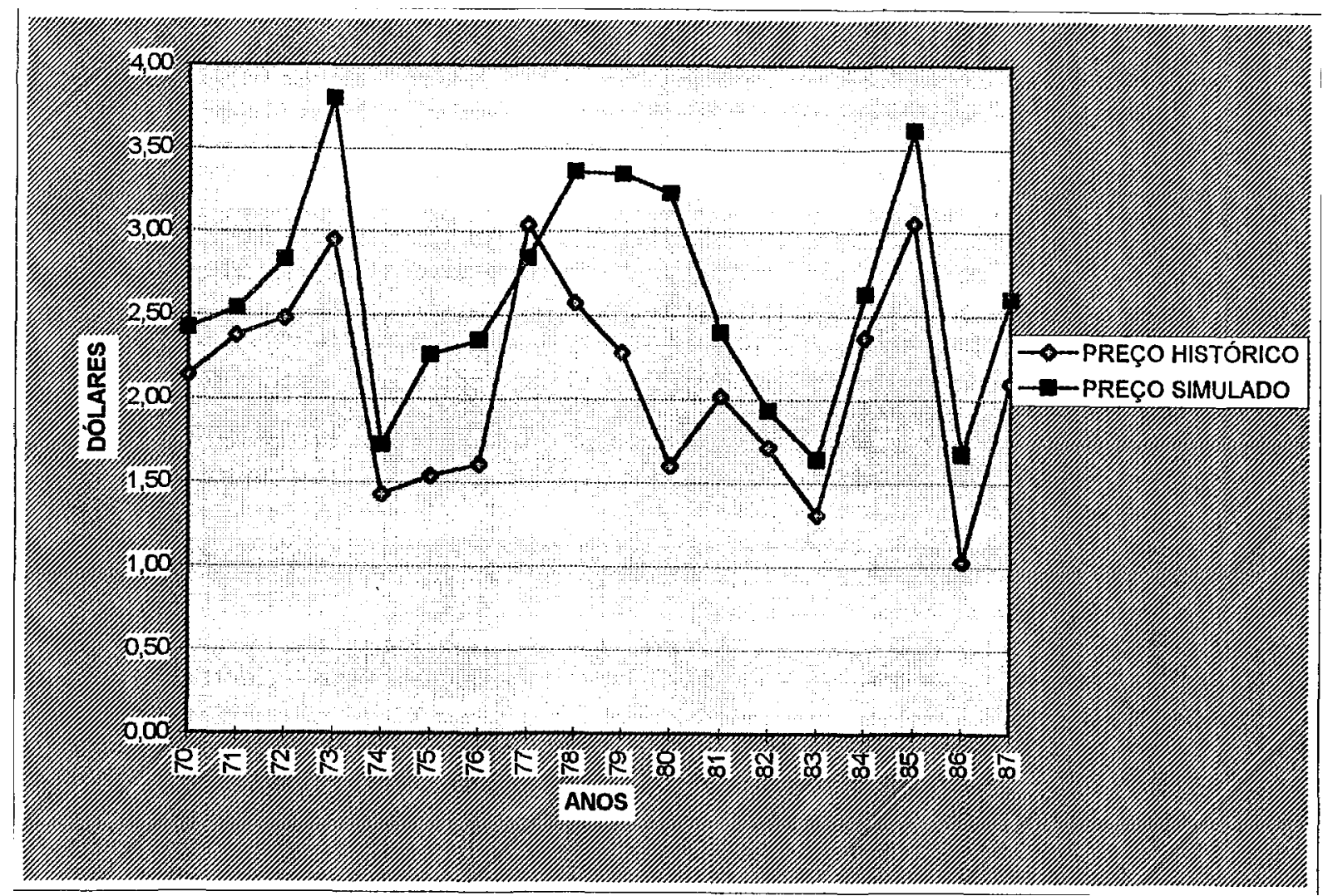

FIGURA 5 - SÃO PAULO: preço histórico e preço simulado da caixa de laranja recebido pelo produtor, em dólares, $1970 / 87$.

Finalmente, na tabela 14 e na figura 6, analisa-se o comportamento da variável pés de laranja plantados no ano. Aqui, mais uma vez, a figura 6 fornece uma avaliação quanto a capacidade do modelo em captar as mudanças repentinas dos novos plantios. Entretanto, o ajuste é apenas razoável com a raiz média quadrática do erro percentual de 44.22\%. Vale destacar a possivel influência dos fatores climáticos nos maiores erros referentes aos anos de 1977, 1981 e 1986, respectivamente anos de geadas no Estado da Flórida e seca no Estado de São Paulo. No tange à regressão entre os valores históricos e simulados, pode-se constatar na tabela 15 que a hipótese $H_{0}: \psi=0$ e $\mu=1$ não é rejeitada ao nível de $1 \%$. Dessa forma, este resultado pode ser aceitável, já que o 
modelo consegue obter, para certos anos, valores simulados não muito afastados dos valores históricos.

TABELA 14: Simulação do número de pés de laranjas plantados no ano no Estado de São Paulo, em milhões - 1970/87.

\begin{tabular}{|c|c|c|c|c|}
\hline ANO & $\begin{array}{l}\text { PÉS PLANTADOS NO } \\
\text { ANO } \\
\text { VALORES } \\
\text { HISTÓRICOS }\end{array}$ & $\begin{array}{l}\text { PES PLANTADOS NO } \\
\text { ANO } \\
\text { VALORES SIMULADOS }\end{array}$ & $\begin{array}{c}\text { ERRO } \\
\text { ABSOLUTO }\end{array}$ & $\begin{array}{c}\text { ERRO } \\
\text { PERCENTUAL }\end{array}$ \\
\hline 1970 & 6,17 & 6,17 & 0,00 & 0,00 \\
\hline 1971 & 5,00 & 6,48 & 1,48 & 29,60 \\
\hline 1972 & 6,20 & 7,53 & 1,33 & 21,45 \\
\hline 1973 & 6,30 & 9,18 & 2,88 & 45,71 \\
\hline 1974 & 13,51 & 13,24 & $-0,27$ & $-2,00$ \\
\hline 1975 & 4,26 & 5,82 & 1,56 & 36,62 \\
\hline 1976 & 5,86 & 7,99 & 2,13 & 36,35 \\
\hline 1977 & 4,72 & 8,01 & 3,29 & 69,70 \\
\hline 1978 & 8,05 & 9,80 & 1,75 & 21,74 \\
\hline 1979 & 15,94 & 11,23 & $-4,71$ & $-29,55$ \\
\hline 1980 & 7,95 & 12,82 & 4,87 & 61,26 \\
\hline 1981 & 5,50 & 11,57 & 6,07 & 110,36 \\
\hline 1982 & 5,90 & 7,65 & 1,75 & 29,66 \\
\hline 1983 & 6,10 & 7,92 & 1,82 & 29,84 \\
\hline 1984 & 3,90 & 3,83 & $-0,07$ & $-1,79$ \\
\hline 1985 & 7,40 & 10,37 & 2,97 & 40,14 \\
\hline 1986 & 8,00 & 12,94 & 4,94 & 61,75 \\
\hline 1987 & 5,00 & 6,33 & 1,33 & 26,60 \\
\hline $\begin{array}{l}\text { DESVIO } \\
\text { PADRÃO }\end{array}$ & 3,01 & 2,66 & 2,31 & 30,70 \\
\hline RMQ & 7,60 & 9,21 & 2,95 & 44,80 \\
\hline MEDIA & 699 & 8.83 & 1.84 & 32.64 \\
\hline
\end{tabular}

As correlações entre os valores observados e estimados ( $r$ ), conforme verifica-se na tabela 15, são todas positivas, com valor médio de aproximadamente 0,85 .

A origem destes erros de simulação para as variáveis endógenas pode estar na própria especificação das equações envolvidas, assim como, secundariamente, em possiveis erros de medida, das variáveis que compõem o modelo. 
No entanto, pode-se afirmar que de um modo geral, os componentes internos do modelo interagem como esperado, refletindo-se numa razoável representação dos valores históricos.

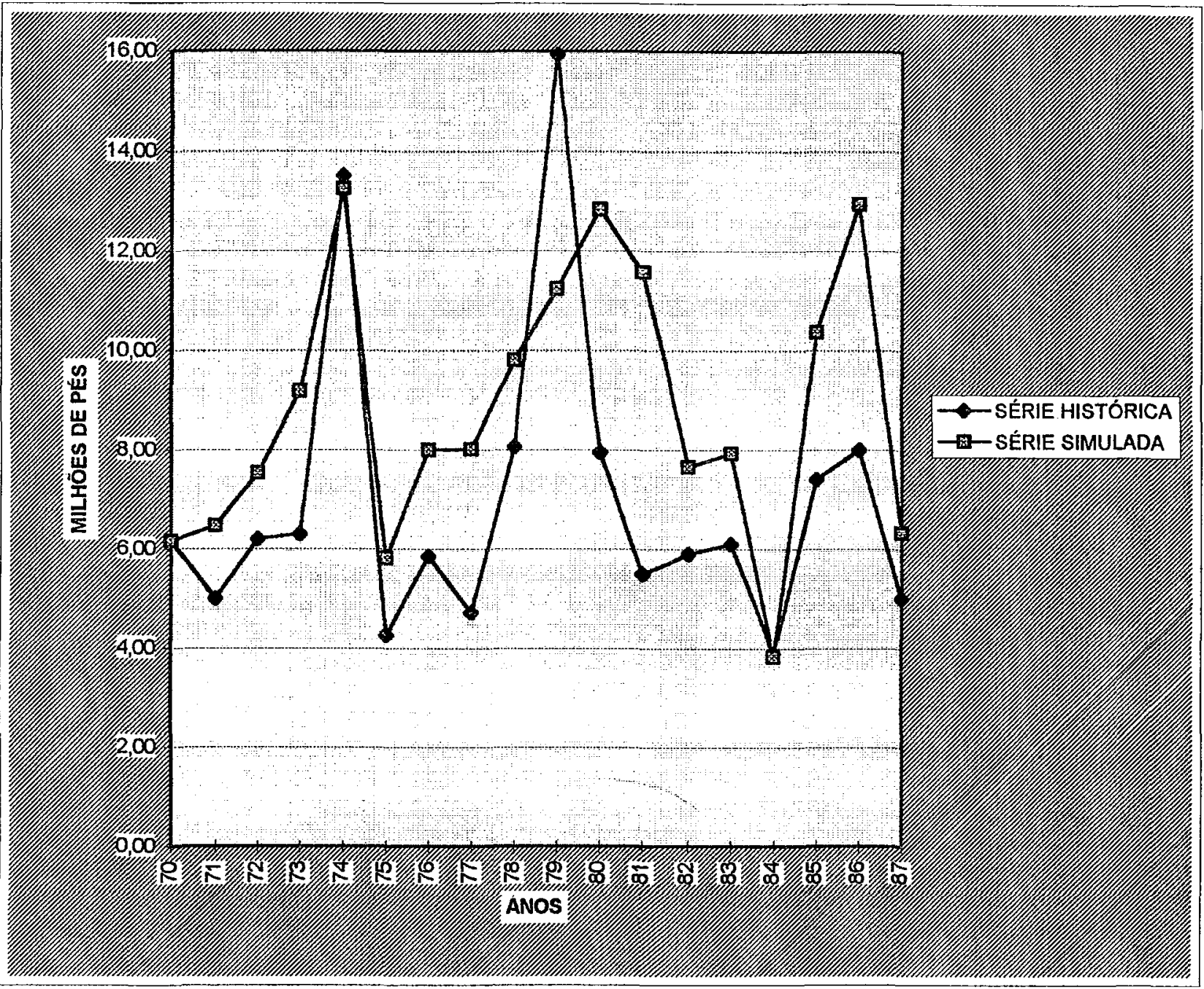

FIGURA 6 - São Paulo: série histórica e série simulada de novos plantios, em milhões de pés, 1970/87 
TABELA 15: Resultados da regressão linear dos valores históricos em função dos valores simulados.

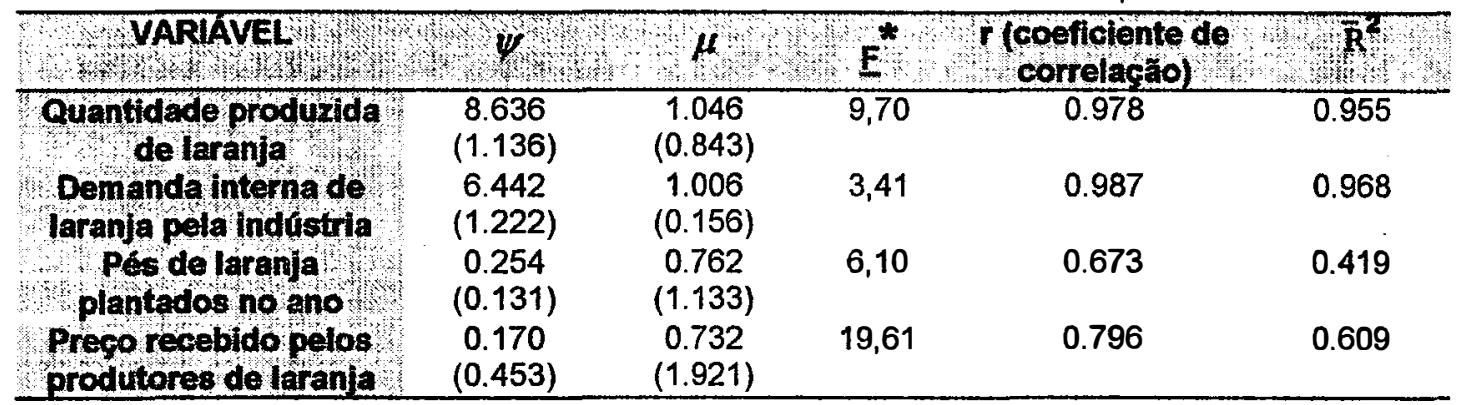

Obs: Os valores entre parênteses correspondem às estatisticas $t$ da distribuição de student para as hipóteses $\mathrm{H}_{0}: \psi=0$ e $\mathrm{H}_{0}: \mu=1$.

* Teste E para a hipótese $\mathrm{H}_{0}: \psi=0$ e $\mu=1$.

\subsubsection{SIMULAÇÃO DOS CENÁRIOS ALTERNATIVOS PARA O MODELO BÁSICO}

Neste ponto, tenta-se responder à questão de como se comportaria o mercado paulista de laranja em relação à eliminação da variável representativa do crédito rural.

Contudo, antes de partir para essa análise, torna-se valioso um comentário sobre essa questão. Vale atentar para a situação simplificadora de uma economia onde prevalece a ausência total de crédito. Aceita-se como mais realista um estudo considerando explicitamente a existência, ou não, de subsídios embutidos no crédito. Convém ressaltar, que essa foi a tentativa inicial, mas, dificuldades fizeram-se presentes na medida em que não foi possivel o levantamento da respectiva série histórica para o período considerado. Sendo assim, o modelo precisou ser adaptado para os dados disponiveis, e, com vistas a que se encontrasse a melhor modelagem que se adequasse aos objetivos da pesquisa, optou-se pela simulação considerando nula a variável representativa do crédito rural. 
A tabela 16 e a figura 7 sintetizam os resultados obtidos. O novo cenário, sem crédito rural, repercutiria, em última instância, em menor produção de laranja, principalmente na segunda metade dos anos 70 e início dos anos 80 , como se pode constatar ao se comparar a nova simulação com os resultados anteriores.

TABELA 16 - Quantidade produzida de laranja no Estado de Såo Paulo, em milhőes de caixas $(40,8 \mathrm{~kg})$. Simulaçöes no modelo básico e no modelo sem crédito rural, $1970 / 87$.

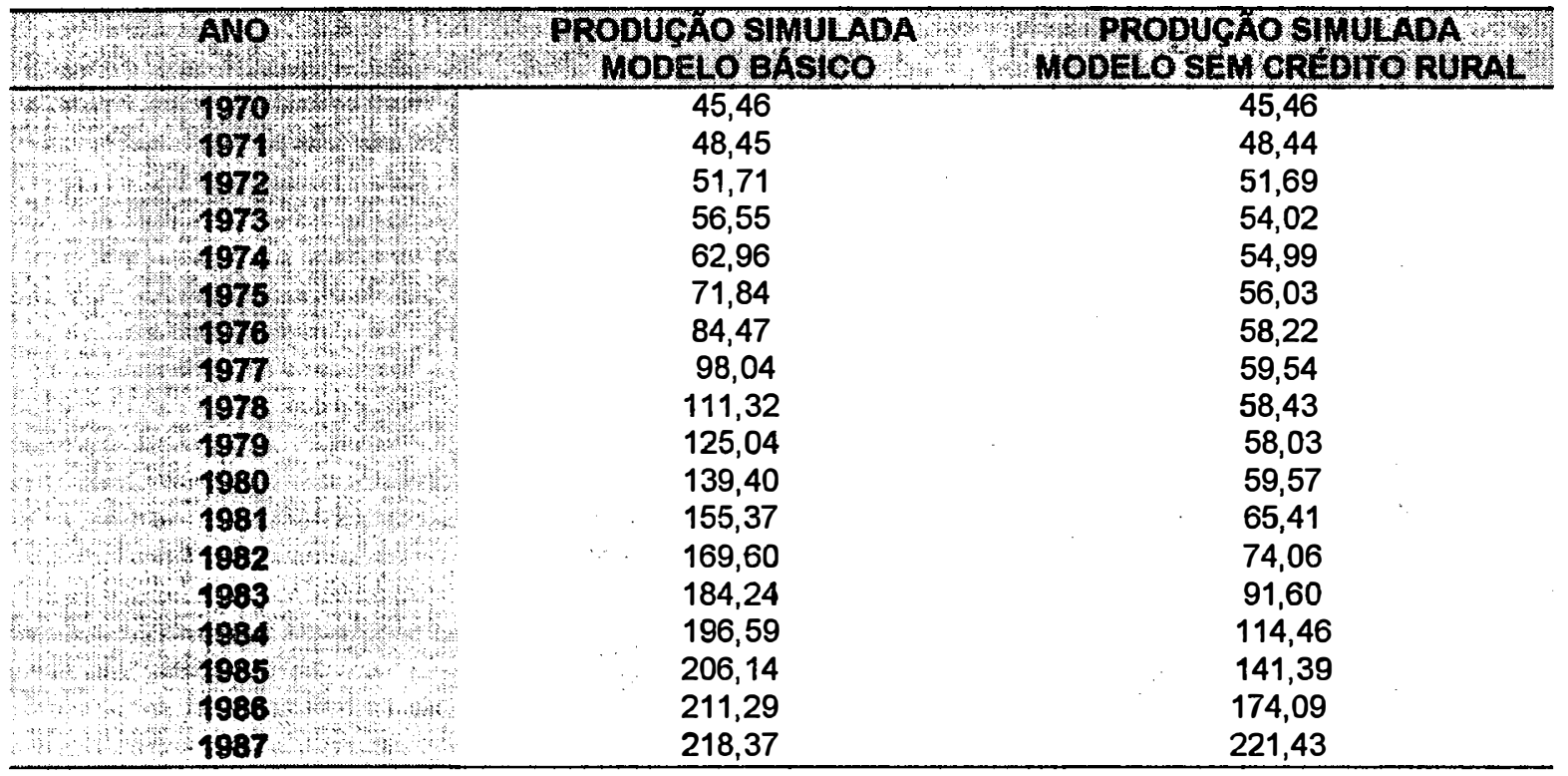




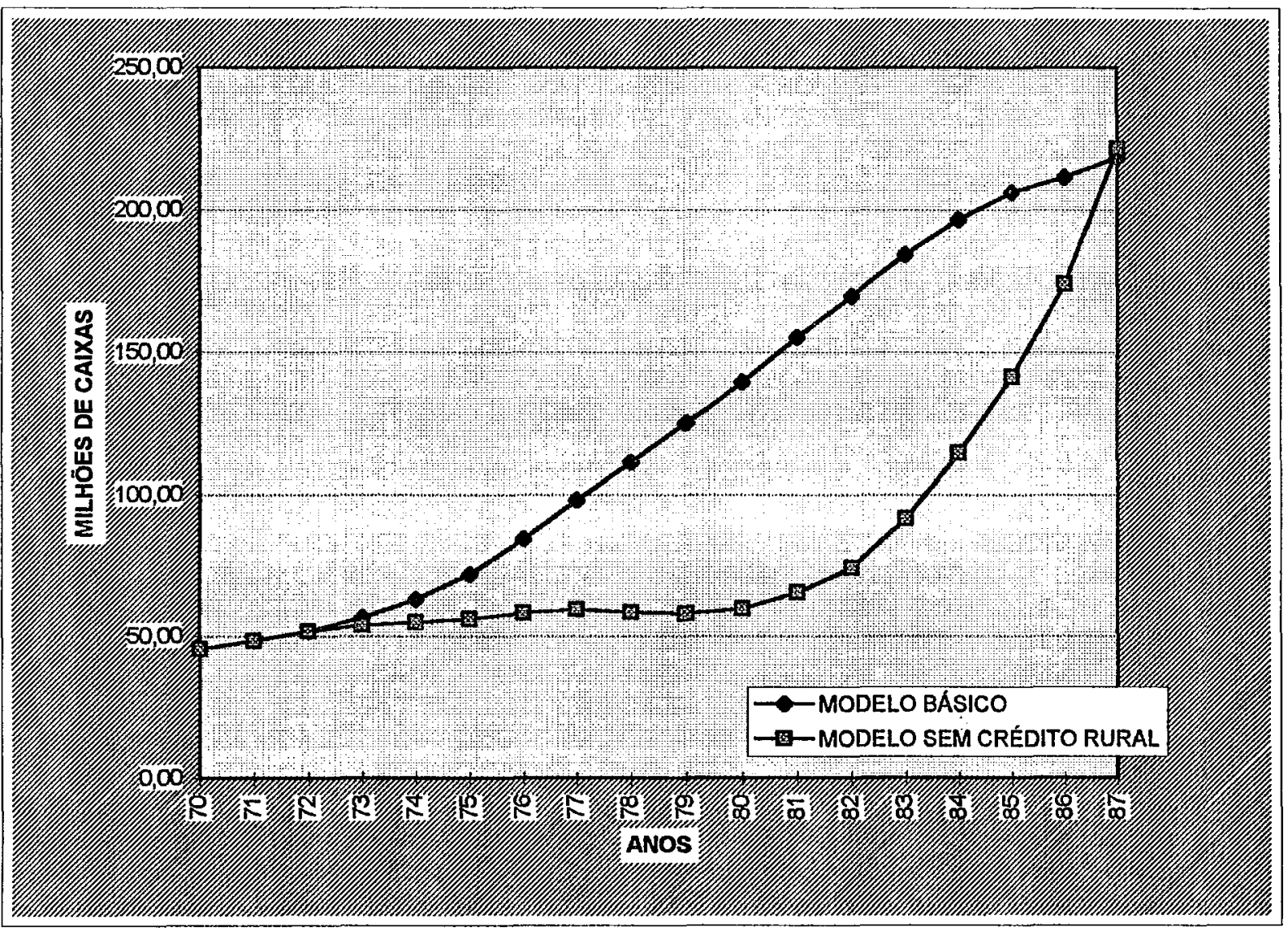

FIGURA 7- SIMULAÇÕES: quantidade produzida de laranja no Estado de São Paulo, em milhões de caixas $(40,8 \mathrm{~kg}), 1970 / 87$.

Conforme pode ser analisado, inicialmente, essa diminuição da produção de laranja poderia ser explicada pela retração, na década de 70 , da variável de novos pés de laranja plantados no ano (tabela 17), haja visto que a mesma incorpora na sua definição a variável $\mathrm{CRED}_{\mathrm{t}-1}$ (equação 15) tornada nula na nova simulação. A queda nos novos plantios causaria um impacto negativo sobre a produção. A queda da produção ocasionaria uma posterior elevação dos preços recebidos pelos produtores cujo efeito repercutiria na diminuição da quantidade demandada de laranja pela indústria (tabela 18). 
TABELA 17: SÃO PAULO - número de pés de laranjas plantados no ano, em milhões. Valores simulados no modelo básico e no modelo sem a participação do crédito rural, 1970/87.

\begin{tabular}{|c|c|c|c|}
\hline ntwh & ANo & $\begin{array}{l}\text { PES PLANTADO NO ANO } \\
\text { MODELO EASICO }\end{array}$ & $\begin{array}{l}\text { PES PLANTADO NOANO } \\
\text { MODELO SEM CREDITO }\end{array}$ \\
\hline 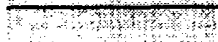 & 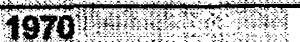 & 6,17 & 6,17 \\
\hline & 1971 wist & 6,48 & 0,66 \\
\hline & 1972 . WW Why & 7,53 & 1,08 \\
\hline & 1973 & 9,18 & 1,26 \\
\hline & 1974 W & 13,24 & 5,59 \\
\hline & 1976 & 5,82 & $-1,67$ \\
\hline & $1976, \quad 2$ & 7,99 & 0,32 \\
\hline & $1977 \%$ & 8,01 & 2,43 \\
\hline & rown & 9,80 & 6,13 \\
\hline 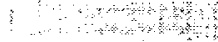 & 1979 & 11,23 & 10,76 \\
\hline & 1980 & 12,82 & 15,35 \\
\hline & $1981 \mathrm{~m} / \mathrm{m}$ & 11,57 & 19,08 \\
\hline 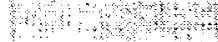 & 1982, & 7,65 & 16,87 \\
\hline Whon & 1983 - 14 & 7,92 & 19,25 \\
\hline 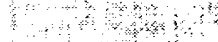 & 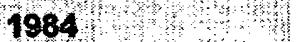 & 3,83 & 25,57 \\
\hline & $1985, \quad \div$ & 10,37 & 45,08 \\
\hline & $1986 \mathrm{~W}$ & 12,94 & 33,48 \\
\hline & 1987 . & 6,33 & 16,35 \\
\hline
\end{tabular}

TABELA 18: Demanda por laranja pela indústria brasileira, em milhões de caixas $(40,8 \mathrm{~kg})$. Valores simulados no modelo básico e no modelo sem a participação do crédito rural, 1970/87.

\begin{tabular}{|c|c|c|c|}
\hline$x_{4}+4$ & ANO & $\begin{array}{l}\text { DEMANDA SIMULADA } \\
\text { MODELO BASICO }\end{array}$ & $\begin{array}{l}\text { DEMANDA SIMULADA } \\
\text { MODELO SEM CREDTTO RURAL }\end{array}$ \\
\hline & 1970 & 27,29 & 27,29 \\
\hline & 1971 & 29,37 & 29,36 \\
\hline & 1972 & 28,82 & 28,80 \\
\hline & 1973 & 33,54 & 31,01 \\
\hline & 1974 & 32,14 & 24,17 \\
\hline & 1975. & 42,38 & 26,57 \\
\hline \% & 1076 & 56,80 & 30,55 \\
\hline W & 1977 & 61,57 & 23,07 \\
\hline $4 x$ & 1978 & 94,42 & 41,53 \\
\hline & 1979 & 114,95 & 47,94 \\
\hline & 1980 & 129,39 & 49,57 \\
\hline & 1981 & 136,47 & 46,52 \\
\hline & 1982 & 145,69 & 50,15 \\
\hline & 1983 & 156,17 & 63,53 \\
\hline & 1984 & 186,55 & 104,44 \\
\hline & 1985 & 196,14 & 131,38 \\
\hline & 1986 & 164,33 & 127,14 \\
\hline & 1987 & 198,36 & 203,42 \\
\hline
\end{tabular}


Vale destacar, que no inicio dos anos 80 , a melhor remuneração via elevação dos preços recebidos pelos produtores, compensaria a ausência do crédito rural na tomada de decisão de novos plantios, fazendo com que a estrutura produtiva praticamente recuperasse o perfil dos dados históricos efetivamente observados no final da década de 80.

Os resultados simulados fornecem evidência de que, caso o governo brasileiro não tivesse adotado uma política de crédito subsidiado para o setor agrícola, provavelmente a produção brasileira da laranjas teria sofrido um processo mais lento de desenvolvimento, ou seja, o crédito funcionou como um estímulo inicial ao crescimento do setor citricola. Porém, vale destacar que a ausência do crédito rural não chegaria a ser um fator estrangulador do seu crescimento, o próprio dinamismo do setor foi capaz de reproduzir uma agricultura e uma indústria comparável, em termos de demanda para processamento e produção de laranja, aos moldes vigentes ao final da década de 80 .

Tendo-se em vista tais resultados, a conclusão que se pode tirar é que a política de crédito agricola subsidiado do governo brasileiro, contribuiu de forma catalisadora para o fortalecimento inicial do setor citrícola paulista. Contudo, mesmo sem o estímulo creditício do governo, o setor foi capaz de consolidar seu atual estágio de desenvolvimento. 
Obviamente, o modelo desenvolvido, em função da necessidade de operacionalização do "programa" da simulação, define algumas variáveis de forma exógena. Conseqüentemente, vale ressaltar que alguns fenômenos relevantes não são captados no modelo. Contudo, espera-se que o estudo desenvolvido sirva de começo para futuras pesquisas, onde posteriores refinamentos podem ser realizados. Em particular, equações adicionais poderiam ser especificadas para endogeneizar a capacidade instalada da indústria e o preço do suco de laranja, relacionando-as à produção interna de laranja, pois, parece mais realista o fato de que um crescimento mais lento da capacidade instalada corresponda a uma menor produção interna de laranja, bem como um maior crescimento do preço do suco de laranja no mercado intemacional. Aplicação potencial do modelo seria desenvolver um sistema de decisões de plantios mais complexo, envolvendo o efeito do preço internacional sobre a produção de outros paises. 


\section{CONCLUSÕES}

Este estudo focalizou a construção de um modelo matemático de oferta e demanda capaz de traçar a trajetória evolutiva para o mercado paulista de laranja. 0 propósito destacado foi analisar o impacto da variável de crédito rural selecionada no sistema.

Um modelo de simulação dinâmica foi desenvolvido para reproduzir o mercado interno de laranja, usando a estrutura dos modelos de resposta para culturas perenes. 0 mercado de laranjas foi simplificado e incorporou o encadeamento entre preços correntes e produção futura através da estimação da equação de novos plantios, cujos resultados mostraram-se razoavelmente satisfatórios. Níveis de quantidade produzida, preços recebidos pelos produtores, demanda interna de laranja pela indústria e pés plantados no ano foram simulados para os anos de 1970 a 1987.

Comparações dos valores históricos com os valores simulados no cenário básico, usadas como forma de validação do modelo, sugerem performance consistente dos resultados com as expectativas teóricas, isto é, os erros obtidos na simulação foram considerados aceitáveis, sendo que as menores divergências entre os valores se deram nas variáveis de quantidade produzida e demanda interna por laranja. Por outro lado, as maiores discrepâncias entre os valores históricos e simulados se deram entre as variáveis de preços e novos plantios. 
Com o fim de responder à questão central do estudo, os resultados de novas simulações alternativas foram comparados com os resultados obtidos no cenário básico. O modelo mostrou sensibilidade à eliminação da variável de crédito rural, ou seja, a produção de laranjas teria sofrido um impacto negativo, principalmente na segunda metade de década de 70 e início da década de 80 , caso o setor não houvesse se beneficiado da ajuda governamental da política de crédito agrícola subsidiado. A queda no número de novos pés de laranja plantados no ano e na demanda por laranja pela indústria brasileira no transcorrer da década de 70 , apresentariam efeito direto sobre a menor produção de laranjas na situação sem crédito rural.

Nesse sentido, examinando os resultados apresentados acima, conclui-se que o crédito rural funcionou como um estímulo inicial ao fortalecimento do setor citrícola paulista. Contudo, vale ressaltar que a simulação parece indicar que a ausência do crédito não chegou a ser um fator estrangulador do seu crescimento, mesmo sem o estímulo creditício do governo, o setor foi capaz de auto-desenvolvimento, isto é, capaz de consolidar uma agricultura e uma indústria comparável aos moldes vigentes ao final da década de 80, tomando-se uma das mais prósperas culturas do Estado e com uma situação de destaque na economia nacional. 


\section{REFERÊNCIAS BIBLIOGRÁFICAS}

ADY, P. Trends in cocoa production. Oxford University Institute Statistics Bulletim. 2: 389404, 1949.

ALBISU, L. M.; BLANDFORD, D. An area response model for perenial plants and its application to Spanish oranges and mandarins. Euro. R. Agr. Eco. 10: 175-184, 1983.

AMARO, A. A.; Industrialização da larania. São Paulo, Secretaria da Agricultura, Instituto de Economia Agrícola, 1973.

AMARO, A. A.; ARAÚJO, C. M.; PORTO, O. M.; DORNElles, C. M. M.; SOBRINHO, A. P. C.; PASSOS, O. S. Panorama da citricultura brasileira. In: FUNDAÇÃO CARGILL. Citricultura brasileira. Campinas, p.23-98, 1980.

AMARO, A. A.; BILLER, V. S. P. Evolução da citricultura paulista. Laranja: Revista TécnicoCientífica de Citricultura. Cordeirópolis, 1:13-26, 1980.

ANUÁRIO ESTATÍSTICO DO BRASIL - Fundação IBGE. Rio de Janeiro, 1967-89.

ANUÁRIO ESTATÍSTICO DO CRÉDITO RURAL. Brasília, BCB, 1969-89.

ARANTES FILHO, A. G. Perspectivas da exportação de suco cítrico nos próximos anos. Laranja: Revista Técnico-científica de Citricultura. Cordeirópolis, 10(1): 45-70, 1989.

BARBOSA, F. H.; SANTIAGO, F. S. Os principais problemas da agricultura brasileira: análise e sugestōes. Rio de Janeiro, IPEA/INPES, 1988. p.243-264. 
BARITELLE, J. L.; PRICE,D. W. Supply response and marketing strategies for deciduous crops. American Joumal of Agricultural Economics. 56: 245-233, 1974.

BASSO, C. A. Oferta de culturas perenes - uma análise econométrica da produção de chá em São Paulo. Viçosa, 1981. 97 p. (Mestrado - Universidade Federal de Viçosa).

BATEMAN, M. J. Aggregate and regional supply functions for ghanaian cocoa, 1946-1963. Joumal of Farm Economics. 47: 384-401, may 1965

BEHRMAN, J. R. Monopolistic coca pricing. American Joumal of Agricultural Economics. $\underline{50}$ 702-719, august 1968.

CAMARGO, A. M. P. Evolução do preço da terra agrícola no Brasil, 1966 a 1986. Agricultura em São Paulo, 36(1): 45-72, 1989.

COMÉRCIO EXTERIOR DO BRASIL: exportação. Rio de Janeiro, Banco do Brasil, CACEX, 1969-89.

COSTA, M. H. Modelo de simulação de choques externos e internos para o mercado brasileiro e exportação do complexo de soja. Viçosa. 1991. 90 p. (Mestrado Universidade Federal de Viçosa).

DI GIORGI, F. A agroindústria citricola no Brasil: novos cenários. Laranja: Revista Técnicocientífica de Citricultura. Cordeirópolis, 12(1): 201-209, 1991. 
FERREIRA, F. L. Suco concentrado de laranja: produção brasileira e mercado internacional. Piracicaba, 1972. (Mestrado - Escola Superior de Agricultura "Luiz de Queiroz"/USP).

FERREIRA, W. B. Oferta de culturas perenes: pimenta do reino no Estado do Pará. Viçosa, 1974. 91 p. (Mestrado - Universidade Federal de Viçosa).

FOOD AND AGRICULTURE ORGANIZATION (FAO). Production yearbook. Roma, Itália, vários volumes.

FUNDAÇÃO GETÚLIO VARGAS (FGV). Conjuntura econômica. Rio de Janeiro, 1969/89..

—. Agroanalysis. Rio de Janeiro, 1981/89.

-. Preços recebidos pelos agricultores. Rio de Janeiro, vários volumes.

FRENCH, B. C. The long-term price and production outlook for apples in the United States and Michigan. Michigan Agricultural Exp. Statistcs Technical Bulletim. 255, april 1956.

FRENCH, B. C.; BRESSLER, R. G. The lemon cycle. Joumal of Farm Economics. 44: 10211036, november 1962.

FRENCH, B. C.; KING, G. A.; MINAMI, D. D. Planting and removal relationships for perennial crops: an application to cling peaches. American Joumal of Agricultural Economics. 67:215-223, 1985. 
FRENCH, B. C.; MATTHEWS, J. L. A supply response model for perennial crops. American Journal of Agricultural Economics. 44: 478-490, 1971.

GALVÃO CÉZAR, S. A. Considerações sobre o papel dos preços e custos nas decisões de plantio no Estado de São Paulo, 1976/86. Piracicaba, 101p. (Mestrado - Escola Superior de Agricultura "Luiz de Queiroz"/USP).

GARCIA, A. Barreiras comerciais à exportação do suco cítrico. Laranja: Revista TécnicoCientifica de Citricultura. Cordeirópolis, 12(1): 1-20, 1991.

GARCIA, A. Suco de laranja - mercado atual e perspectivas. Laranja: Revista TécnicoCientífica de Citricultura. Cordeirópolis, 13(1): 1-28, 1992.

HARTLEY, M. J.; NERLOVE, M.; PETER, R. K. An analysis of rubber supply in Sri Lanka. American Joumal of Agricultural Economics. 69:755-761, 1987.

HASSE, G. A laranja no Brasil - 1500-1987. Duprat/IOBE, São Paulo, 1987.

hOFFMANN, R.; SERRANO, O.; NEVES, E. M.; THAME, A. C. M.; ENGLER, J. J. C. Administração da empresa agrícola. 5a edição. São Paulo, Pioneira, 1987.

HOFFMANN, R. ; VIEIRA, S. Análise de regressão - uma introdução à econometria. 2 a. edição. São Paulo. Editora Hucitec, 1977.

IANNINI, P. L. Mercado interno de fruta cítrica in natura Laranja: Revista Técnico-científica de Citricultura. Cordeirópolis, 13(1): 165-188, 1992. 
INFORMAÇÕES ECONÓMICAS. São Paulo, Secretaria de Agricultura e Abastecimento, IEA, vários volumes.

JOHNSTON, J. Econometric methods. 2. ed. McGraw-Hill, 1972.

KALAITZANDONAKES, N. G. Investment decisions and supply response for perennial crops: the case of Florida citrus. Gainesville, 1990. 147p. (PHD - University of Florida).

KMENTA, J. Elementos de Econometria. São Paulo, Atlas, 1978.

KOST, W. E. Model validation and the net trade model. Agric. Econ. Res. 32(2): 1-16, april 1980.

LADEIRA, H. H. Avaliação econométrica da oferta de café em Minas Gerais. Viçosa, 1974. 103 p. (Mestrado - Universidade Federal de Viçosa).

LAFER, C. O planejamento no Brasil - Observações sobre o plano de metas (1956-1961). Perspectiva, p. 29-50, São Paulo, 1970.

MAIA, M. L. Citricultura paulista: evolução, estrutura e acordos de preços. Piracicaba, 1992. 185p. (Mestrado - Escola Superior de Agricultura "Luiz de Queiroz"/USP).

MANOS, B.; PAPANAGIOTOU, E. Fruit-tree replacement in discrete time: am application in Central Macedonia. Euro. R. Agr. Eco. 10: 69-78, 1983. 
MARTIN, N. B. Transformação da agricultura paulista na década de setenta e simulação de politica de crédito rural. São Paulo, 1981. (Mestrado - Faculdade de Economia e Administração/USP).

MARTINELLI JÚNIOR, O. O complexo agroindustrial no Brasil: um estudo sobre a agroindústria citrícola no Estado de São Paulo. São Paulo, 1987. (Mestrado - Faculdade de Economia e Administração/USP).

McCLAIN, E. A. A. Monte carlo simulation model of the world orange juice market. Gainesville, 1989. 157p. (PHD - University of Florida).

MOREIRA, C.S.; MOREIRA , S. História da citricultura no Brasil. In: FUNDAÇÃO CARGILL. Citricultura brasileira . Campinas, p. 1-28, 1980.

MUTH, J. F. Rational expectations and the theory of price movements. Econometrica 29:315-335, 1961.

NAMEKATA, Y. Modelos alternativos de oferta: o caso dos citros no Estado de São Paulo. Viçosa, 1977. 81 p. (Mestrado - Universidade Federal de Viçosa).

NERLOVE, M. Estimates of the elasticities of supply of selected agricultural commodities. Journal of Farm Economics. 38: 496-509, may 1956.

-; BUCHMAN, K. L. The analysis of changes in agricultural supply: problems and approaches. Journal of Farm Economics. 42: 531-551, august 1960. 
NEVES, E. M. Citricultura paulista: importância econômica e perspectivas. Laranja: Revista Técnico-cientifica de Citricultura. Cordeirópolis, 13(1): 55-62, 1992.

NEVES, E. M.; ANDIA, L. H.; NEVES, M. F.; BARROS, S. S. Economia da produção citricola: Competitividade sob o enfoque de custos e investimentos. In: XXX CONGRESSO BRASILEIRO DE ECONOMIA E SOCIOLOGIA RURAL, Rio de Janeiro, 03-06/08/92. Anais, vol II, SOBER. p.525-37, 1992.

NORONHA, J. F.; GASQUES, J. G.; AMARO, A. A. Análise econométrica da oferta e demanda de laranja no Estado de São Paulo. Revista de Economia Rural. Brasília, 16(2):79-96, abr.jun. 1978.

REYDON, B. P. Mercados de terras agrícolas e determinantes de seus preços no Brasil: um estudo de casos. Campinas, 1992. 322 p. (Doutorado- Universidade de Campinas).

RIBEIRO, J. H. Gota de sol - a viagem da laranja, desde sua descoberta nos jardins da China aos navios sucoleiros de hoje. 2a. edição. São Paulo. Editora Globo, 1992.

SALIBE, A. A. Citricultura: problemas importantes de outros países. In: FUNDAÇÃO CARGILL. Citricultura brasileira. Campinas, p.923-939, 1980.

SAYLOR, R. G. A resposta da área de café em São Paulo às variações de preço. Agricultura em São Paulo. São Paulo, 20(1/2):43-59, 1973.

SHIROTA, R. Crédito Rural no Brasil: subsidio, distribuição e fatores associados à oferta. Piracicaba, 1988. 229 p. (Mestrado - Escola Superior de Agricultura "Luiz de Queiroz"/USP). 
SILVA, D. C. Números da citricultura mundial. São Paulo. Coinbra-Frutesp, 1994.

SILVA, O. M. The internacional market for frozen concentraded orange juice - prospects for Brazil. Raleigh, North Carolina, 1990. 136p. (PHD - Caroline State University).

SPENCE, R. Clipper 5.0 - release 5.01. São Paulo. Editora Makron Books, 1991.

UNITED STATES DEPARTMENT OF AGRICULTURE (USDA). Horticultural products review, vários volumes. 


\section{APÊNDICE 1}

\section{O PROGRAMA DA SIMULAÇÃO}

O programa para a simulação foi escrito na linguagem CLIPPER 5.01. Esta seção considera informações sobre o mesmo e lista seus arquivos fonte.

A figura 8 representa o comportamento do sistema, onde a partir do gerenciamento do menu principal, os dados de entrada e saída são cadastrados. O programa está dividido em dois componentes principais de cadastros e de execução. A função de cadastros, por sua vez, subdivide-se em cadastro para oferta, demanda, coeficientes e resultados, como ilustrado na figura.

O teste do algoritmo foi feito rastreando seu comportamento em situações simplificadas. Os resultados gerados por situações hipotéticas pré-concebidas foram semelhantes aos resultados obtidos pela simulação.

O programa trabalha da seguinte forma. Primeiro, o usuário fornece as informações referentes às séries históricas para as variáveis exógenas que compõem o modelo básicò para novos plantios (oferta) e demanda. O passo seguinte é cadastrar os coeficientes estimados das referidas funções. A próxima etapa corresponde a execução da simulação. Nesta fase, são definidas as condições iniciais para a simulação, tais como as dimensões dos vetores envolvidos, as taxas de sobrevivência, a distribuição das árvores por idade, o número de novas árvores plantadas, os rendimentos das árvores por idade e a taxa de crescimento anual do rendimento. O modelo é, então, executado e os resultados armazenados no seu respectivo cadastro. 


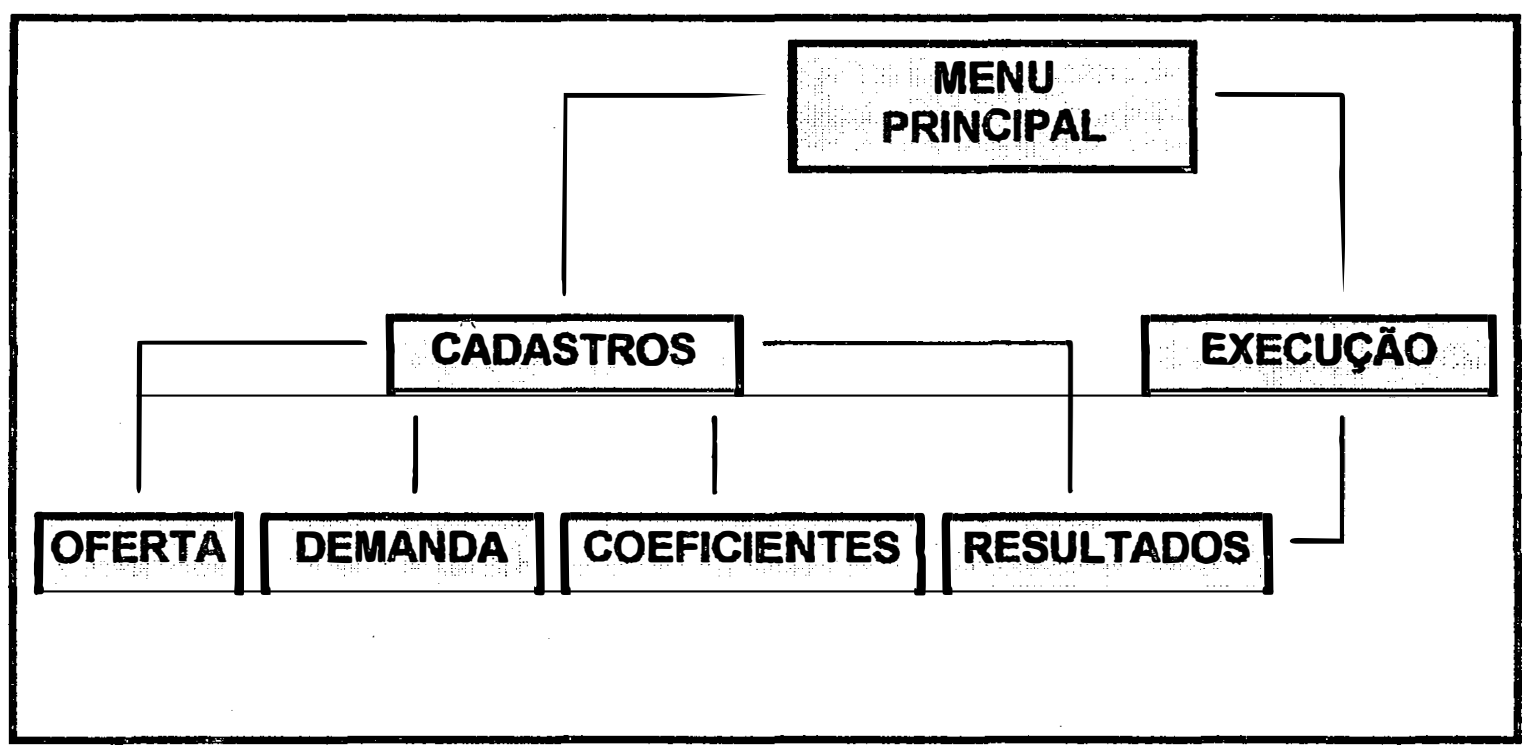

FIGURA 8: Fluxograma Geral do Programa da Simulação

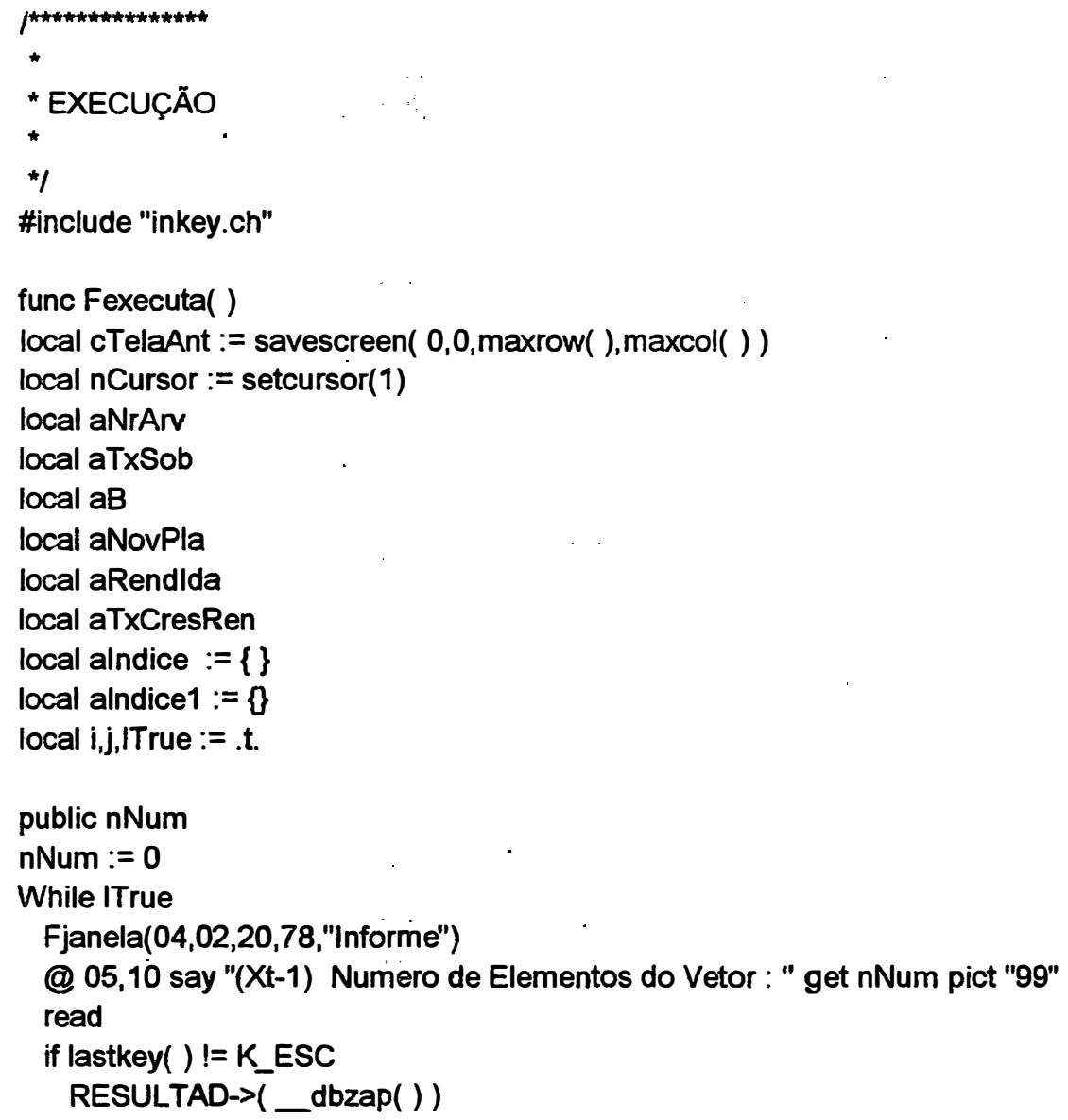




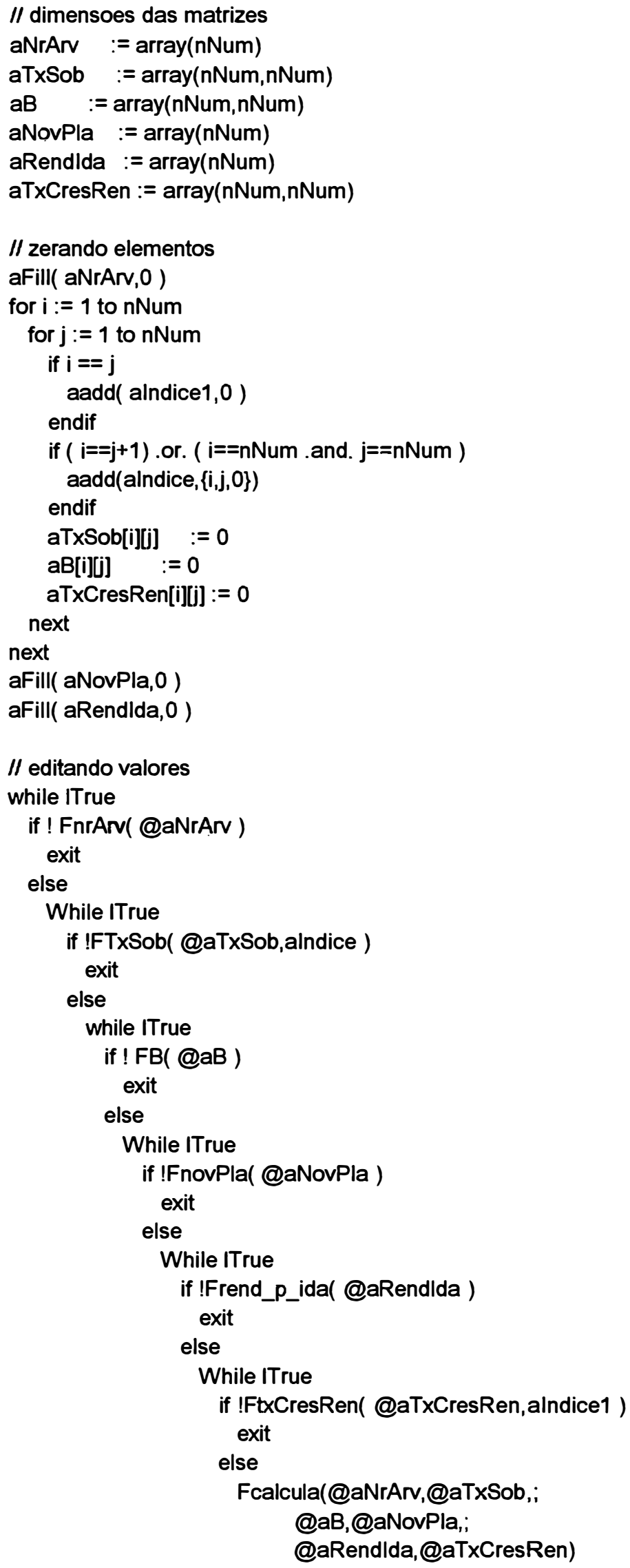




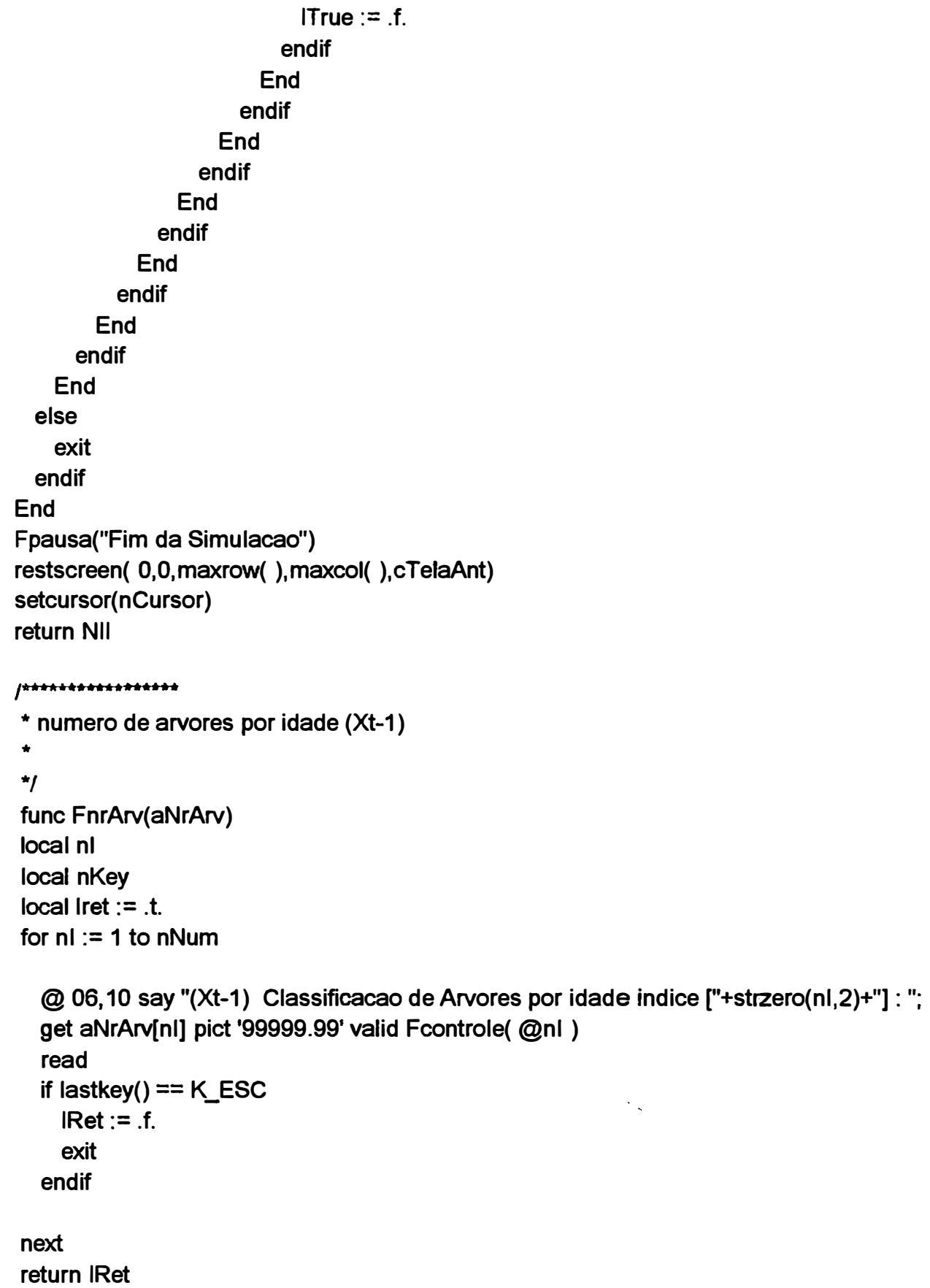




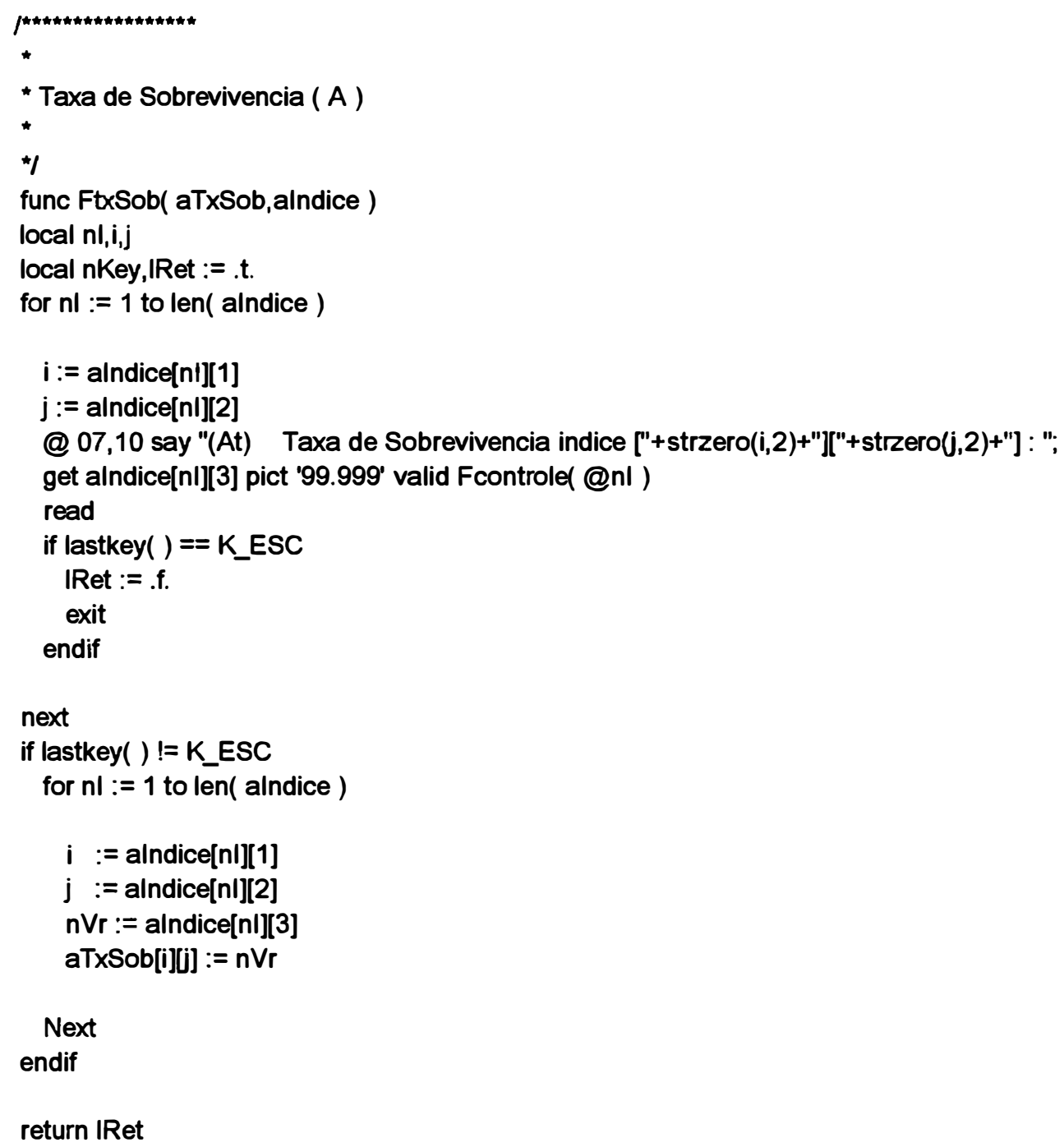


" Novos Plantios ( aNovPla )

*

*I

func FnovPla( aNovPla )

local IRet $:=$. .t.

local nVar : $=0$

@ 09,10 say "(Ut-1) Novos Plantios indice [1] : ";

get $n$ Var pict ' 99999.99 ' valid $n$ Var $>0$

read

if lastkey( ) ! = K_ESC

aNovPla[1]:= nVar

else

IRet := .f.

endif

return IRet

/

$\star$

* rendimento por idade (Yt-1)

*I

func Frend_p_ida(aRendlda)

local $\mathrm{nl}$

local nKey

local Iret := .t.

for $\mathrm{nl}:=1$ to $\mathrm{nNum}$

@ 10,10 say "(Yt-1) Rendimento por Idade indice ["+strzero(nl,2)+"] : "; get aRendlda[nl] pict '999.999' valid Fcontrole( @nl )

read

if lastkey( $)==$ K_ESC

IRet := .f.

exit

endif

next

return IRet

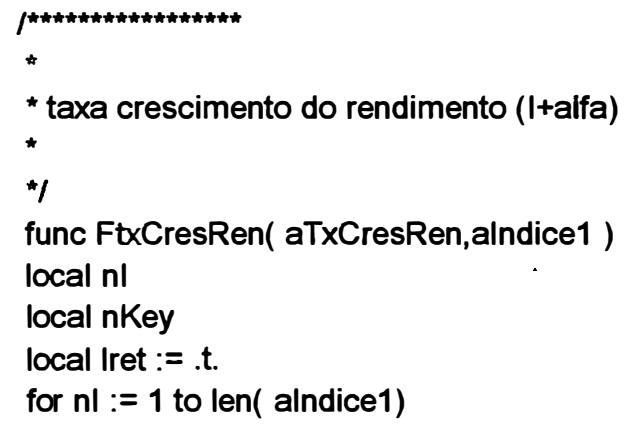

@ 11,10 say "(I+Alfa)Taxa Crescimento do Rendimento indice ["+strzero(nl,2)+"]["+strzero(nl,2)+"] : "; get alndice1[nl] pict '999.999' valid Fcontrole( @nl ) 


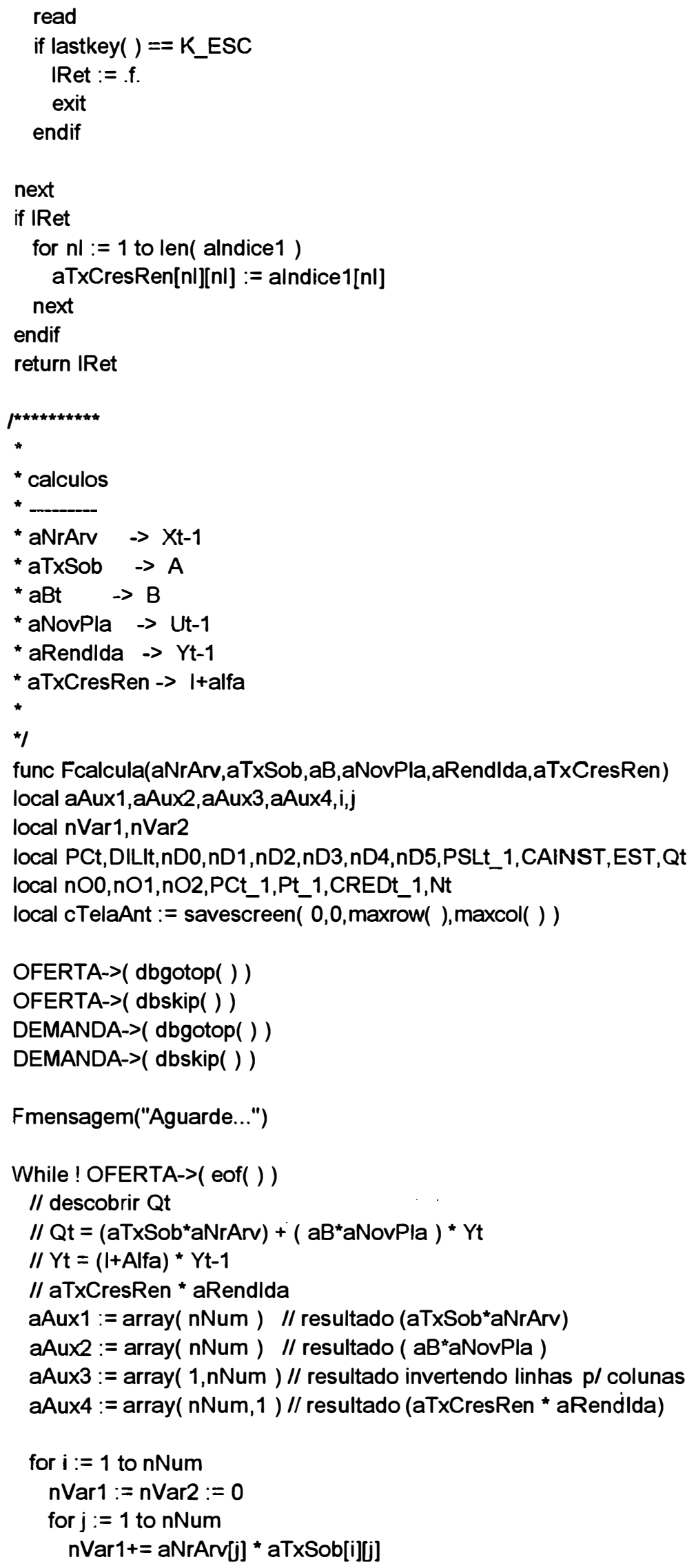




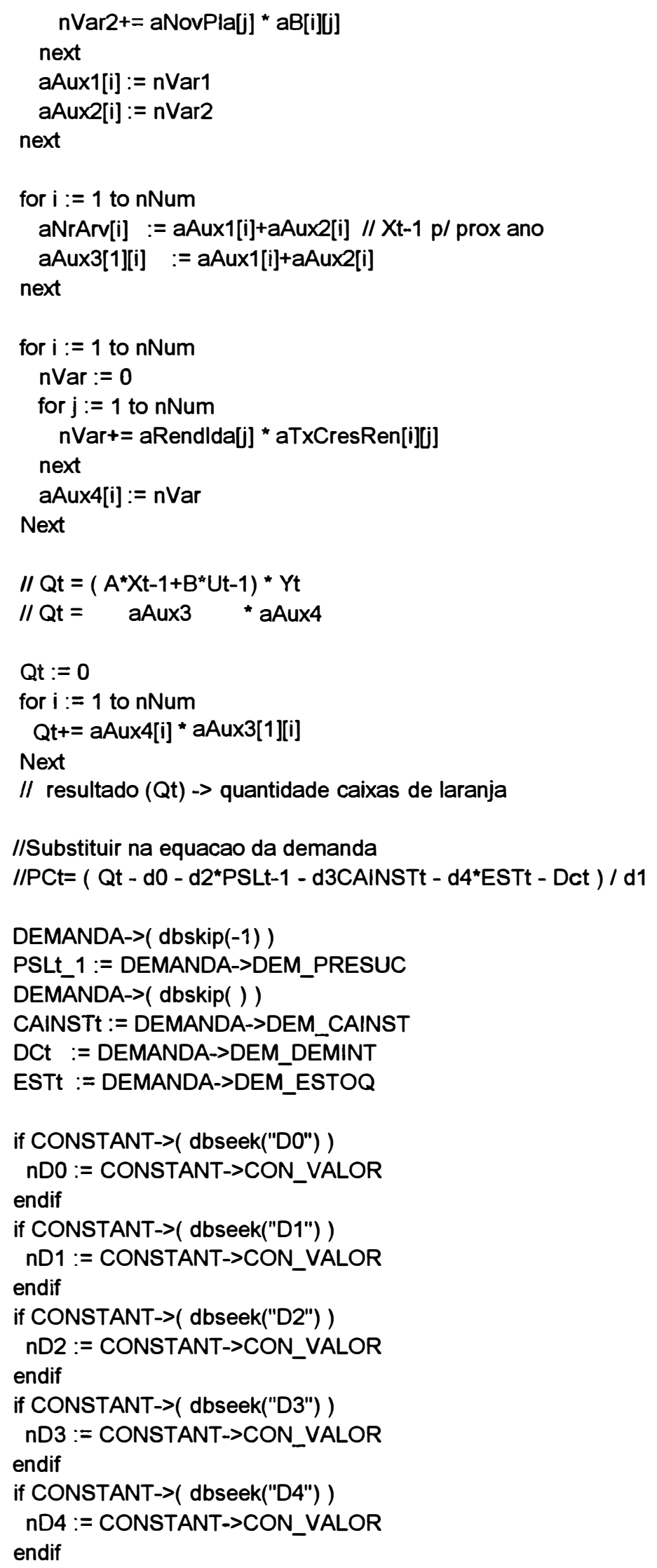




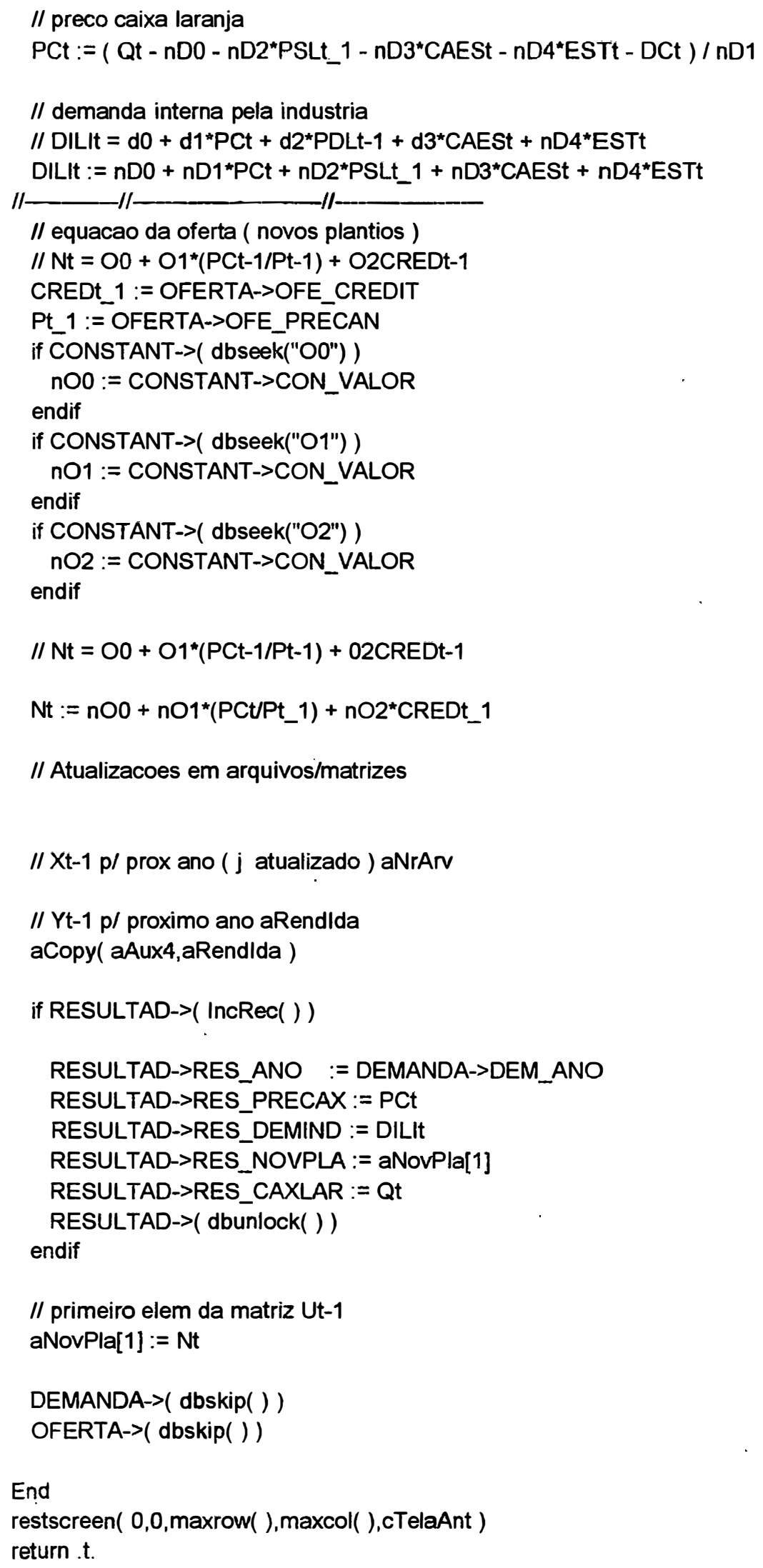




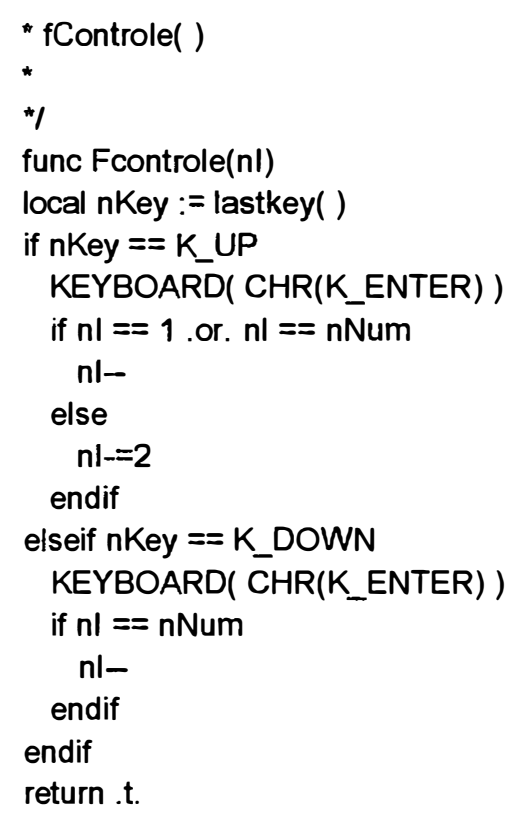




\section{APÊNDICE 2}

\section{DADOS UTILIZADOS NA TESE}

LARANJA- SÃO PAULO: número de pés plantados no ano e preço recebido pelo citricultor.

\begin{tabular}{|c|c|c|c|}
\hline ANO & $\begin{array}{l}\text { PES PLANTADOSNO } \\
\text { ANO } \\
\text { (milhoes de pes) }\end{array}$ & $\begin{array}{l}\text { PRECO NOMINAL RECEBIDO } \\
\text { PELO CITRICULTOR } \\
\text { (USSTCX) }\end{array}$ & $\begin{array}{l}\text { PREGOREAL RECEBIBO } \\
\text { PELO CITRICUL TOR (US\%1OX) } \\
\text { (BASE 1880) }\end{array}$ \\
\hline $1969 \%$ & 7,39 & 1,43 & 3,60 \\
\hline 1970 & 6,17 & 0,88 & 2,14 \\
\hline 1971 & 5,00 & 1,01 & 2,38 \\
\hline 1972 & 6,00 & 1,10 & 2,48 \\
\hline 1973 & 6,30 & 1,48 & 2,95 \\
\hline 1974 & 13,51 & 0,85 & 1,43 \\
\hline 1975 & 4,26 & 1,00 & 1,54 \\
\hline 1976 & 5,86 & 1,10 & 1,61 \\
\hline 1977 & 4,72 & 2,20 & 3,04 \\
\hline 1978 & 8,05 & 2,00 & 2,57 \\
\hline 1979 & 15,94 & 2,00 & 2,28 \\
\hline $1980^{*}$ & 7,95 & 1,60 & 1,60 \\
\hline 1981 & 5,50 & 2,20 & 2,02 \\
\hline 1982 & 5,90 & 1,90 & 1,71 \\
\hline 1983 & 6,10 & 1,48 & 1,31 \\
\hline 1984 & 3,90 & 2,74 & 2,37 \\
\hline 1985 & 7,40 & 3,50 & 3,05 \\
\hline 1986 & 8,00 & 1,15 & 1,03 \\
\hline 1987 & 5,00 & 2,41 & 2,10 \\
\hline 1988 & 8,90 & 3,74 & 3,14 \\
\hline 1989 & 15,80 & 3.53 & 2.83 \\
\hline
\end{tabular}

FONTE: IEA

* A partir de 1980, os dados para pés plantados no ano são ajustados a partir de informaçőes da ABECITRUS - Associação Brasileira dos Exportadores de Cítricos e do IEA que publica dados referentes a número de pés novos incluindo árvores com menos de 3 anos de idade. 
CANA DE AÇÚCAR-SÃO PAULO: preço médio recebido pelo produtor.

\begin{tabular}{|c|c|c|c|}
\hline ANO & $\begin{array}{l}\text { PREÇO MEDIO NOMINAL } \\
\text { RECEBIDO PELO PRODUTOR } \\
\text { (Crston) }\end{array}$ & $\begin{array}{l}\text { PRECOO REAL MEDIO } \\
\text { RECEBIDO PELO PRODUTOR } \\
\text { USSHTON (BASE=1980) }\end{array}$ & (n) \\
\hline 1969 & 17,02 & & 10,08 \\
\hline 1970 & 19,36 & & 9,51 \\
\hline 1971 & 22,86 & & 9,55 \\
\hline 1972 & 27,52 & & 10,45 \\
\hline 1973 & 31,70 & & 10,32 \\
\hline 1974 & 49,29 & & 12,17 \\
\hline 1975 & 75,18 & & 14,20 \\
\hline 1976 & 105,59 & & 14,52 \\
\hline 1977 & 148,42 & & 14,52 \\
\hline 1978 & 199,93 & & 14,20 \\
\hline 1979 & 310,94 & & 13,18 \\
\hline 1980 & 664,47 & & 12,61 \\
\hline 1981 & 1384,98 & & 13,63 \\
\hline 1982 & 2481,37 & & 12,43 \\
\hline 1983 & 6225,16 & & 9,59 \\
\hline 1984 & 13285,00 & & 6,24 \\
\hline 1985 & 54258,50 & & 7,62 \\
\hline 1986 & 102893,30 & & 6,76 \\
\hline 1987 & 346870,00 & & 7,71 \\
\hline 1988 & 2218972,50 & & 7,09 \\
\hline 1989 & 25646666,60 & & 7,22 \\
\hline
\end{tabular}

FONTE: FGG-CFP

SÃO PAULO - ATIVIDADE AGRÍCOLA: Financiamentos concedidos a produtores e cooperativas.

\begin{tabular}{ccc}
\hline ANO & $\begin{array}{c}\text { VALORES NOMINAIS } \\
\text { (Cr\$ 1000) }\end{array}$ & $\begin{array}{c}\text { VALORES REAIS (US\$) } \\
\text { BASE=1960 }\end{array}$ \\
\hline 1969 & 2143250.00 & 1269,44 \\
1970 & 3086730.00 & 1516,57 \\
1971 & 4024347.00 & 1681,39 \\
1972 & 5435876.00 & 2064,77 \\
1973 & 6690168.00 & 2177,05 \\
1974 & 9894749.00 & 2444,19 \\
1975 & 15017240.00 & 2837,43 \\
1976 & 20484628.00 & 2817,77 \\
1977 & 30214475.00 & 2956,51 \\
1978 & 41298989.00 & 2932,77 \\
1979 & 74887817.00 & 3176,26 \\
1980 & 148968649.00 & 2826,78 \\
1981 & 262549250.00 & 2584,36 \\
1982 & 569677204.00 & 2853,07 \\
1983 & 1063215718.00 & 1637,34 \\
1984 & 1931157344.00 & 906,70 \\
1985 & 7650171770.95 & 1073,89 \\
1986 & 23548857249.57 & 1547,26 \\
1987 & 65384473922.87 & 1453,04 \\
1988 & 413019673000.00 & 1319,68 \\
1989 & 3991595842650.00 & 1123,10 \\
\hline
\end{tabular}

FONTE: Banco Central do Brasil 
SÃO PAULO - Preço de venda terras lavoura, em Cr\$ (base=jun/91).

\begin{tabular}{crr}
\hline ANO & TERRA DE PRIMEIRA & TERRA DE SEGUNOA \\
\hline 1970 & 259844,30 & 279747,87 \\
1971 & 289657,39 & 306589,16 \\
1972 & 382657,83 & 449659,61 \\
1973 & 699042,55 & 916990,02 \\
1974 & 863943,16 & 892311,54 \\
1975 & 1019530,44 & 1030015,46 \\
1976 & 950493,90 & 1026905,78 \\
1977 & 924235,06 & 972104,78 \\
1978 & 1054469,56 & 941132,30 \\
1979 & 1018023,87 & 904866,94 \\
1980 & 979163,23 & 929760,96 \\
1981 & 1040151,40 & 933483,07 \\
1982 & 902827,18 & 790482,25 \\
1983 & 660496,91 & 513686,95 \\
1984 & 626227,84 & 748370,34 \\
1985 & 800285,56 & 746006,16 \\
1986 & 1231336,78 & 2134831,88 \\
1987 & 885967,42 & 781317,20 \\
1988 & 578291,08 & 427784,32 \\
1989 & 1191297,68 & 428757,16 \\
\hline
\end{tabular}

FONTE: REYDON (1992)

LARANJA- número de árvores, quantidade produzida, produtividade e processamento no Estado de São Paulo.

\begin{tabular}{|c|c|c|c|c|}
\hline ANO & $\begin{array}{l}\text { NUMERO DE } \\
\text { ARVORES } \\
\text { (milhoes) }\end{array}$ & 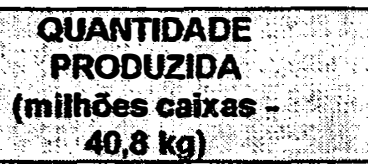 & $\begin{array}{l}\text { PRODUTIVIDADE } \\
\text { (calxas/pe) }\end{array}$ & $\begin{array}{l}\text { PROGESSAMENTO } \\
\text { (milhoes calxas of } \\
40,8 \mathrm{~kg}) \text { ) }\end{array}$ \\
\hline 1969 & 32,8 & 35 & 1,07 & 8,2 \\
\hline 1970 & 39,0 & 44 & 1,13 & 15,0 \\
\hline 1971 & 44,0 & 46 & 1,05 & 25,0 \\
\hline 1972 & 50,2 & 61 & 1,22 & 34,3 \\
\hline 1973 & 56,5 & 62 & 1,10 & 39,6 \\
\hline 1974 & 70,0 & 82 & 1,20 & 55,1 \\
\hline 1975 & 74,2 & 85 & 1,15 & 52,0 \\
\hline 1976 & 75,9 & 100 & 1,32 & 69,0 \\
\hline 1977 & 79,2 & 92 & 1,16 & 60,0 \\
\hline 1978 & 87,3 & 150 & 1,72 & 117,0 \\
\hline 1979 & 1032 & 155 & 1,50 & 124,0 \\
\hline 1980 & 106,0 & 170 & 1,60 & 138,0 \\
\hline 1981 & 106,2 & 180 & 1,69 & 155,0 \\
\hline 1982 & 109,3 & 195 & 1,78 & 161,0 \\
\hline 1983 & 1130 & 200 & 1,76 & 165,0 \\
\hline 1984 & 117,0 & 205 & 1,75 & 185,0 \\
\hline 1985 & 129,0 & 239 & 1,85 & $220 ; 0$ \\
\hline 1986 & 136,0 & 220 & 1,60 & 163,0 \\
\hline 1987 & 139,0 & 210 & 1,51 & 185,0 \\
\hline 1988 & 160,0 & 195 & 1,21 & 175,0 \\
\hline
\end{tabular}

FONTE: IEA, USDA 
SÃO PAULO - Preço real da muda da laranja (Cr\$/unidade).

\begin{tabular}{|c|c|c|}
\hline & ANO & $\begin{array}{l}\text { PREÇO REAL DA MUDA } \\
\text { (BASE }=1980)\end{array}$ \\
\hline & 1969 & 0,000032 \\
\hline & 1970 & 0,000035 \\
\hline & 1971 & 0,000037 \\
\hline & 1972 & 0,000038 \\
\hline & 1973 & 0,000040 \\
\hline & 1974 & 0,000041 \\
\hline & 1975 & 0,000050 \\
\hline & 1976 & 0,000041 \\
\hline & 1977 & 0,000039 \\
\hline & 1978 & 0,000044 \\
\hline & 1979 & 0,000045 \\
\hline 3 & 1980 & 0,000040 \\
\hline & 1981 & 0,000038 \\
\hline & 1882 & 0,000039 \\
\hline & 1983 & 0,000040 \\
\hline & 1984 & 0,000054 \\
\hline & 1985 & 0,000078 \\
\hline & 1986 & 0,000065 \\
\hline & 1083 & 0,000040 \\
\hline & 1988 & 0,000041 \\
\hline $0=3$ & 1989 & 0,000048 \\
\hline
\end{tabular}

FONTE: IBRE, FGV

BRASIL - LARANJA: capacidade de esmagamento, estoque de suco.

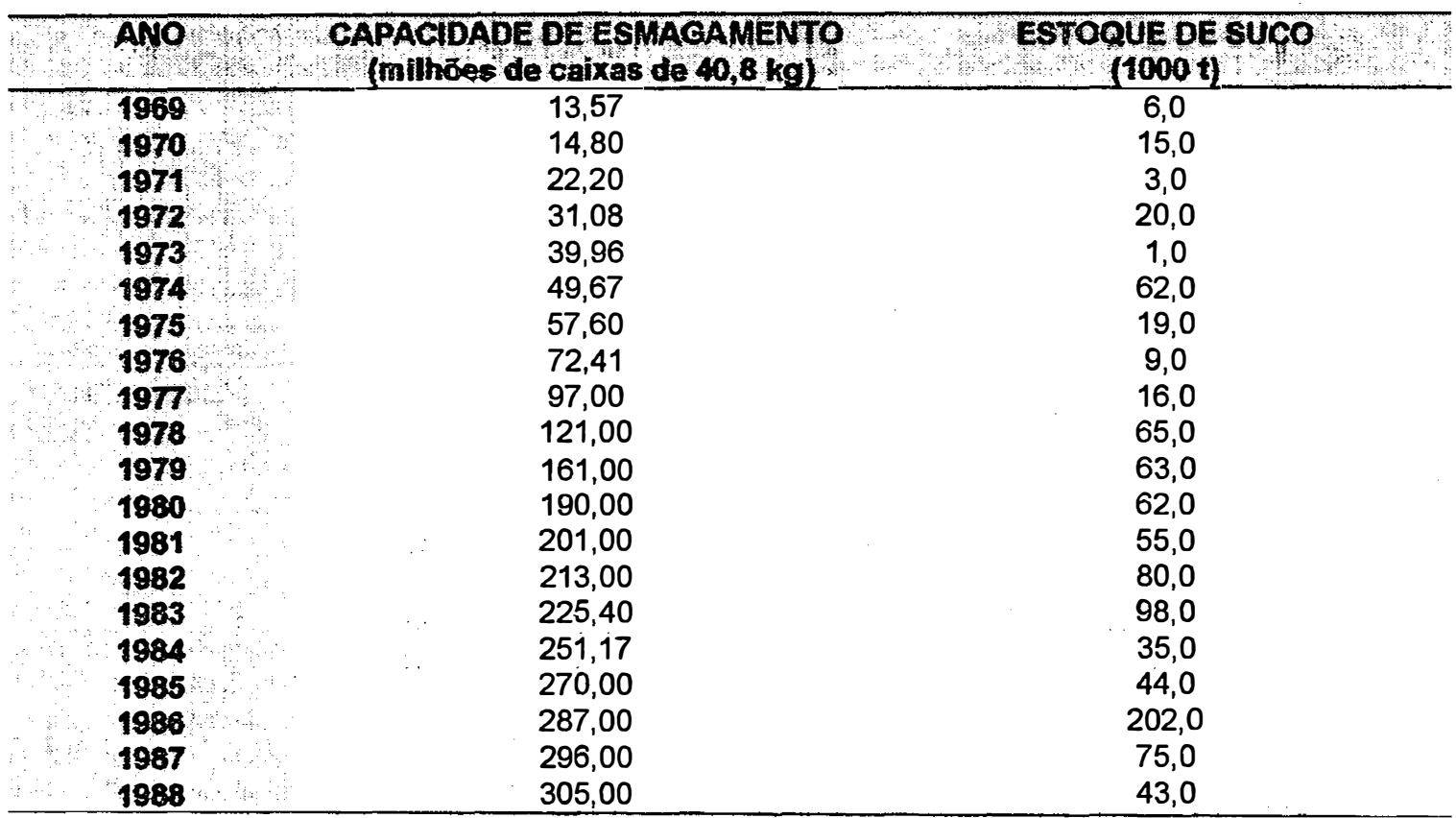

FONTE: Informaçoes obtidas junto ao setor 
SUCO DE LARANJA: preço real internacional.

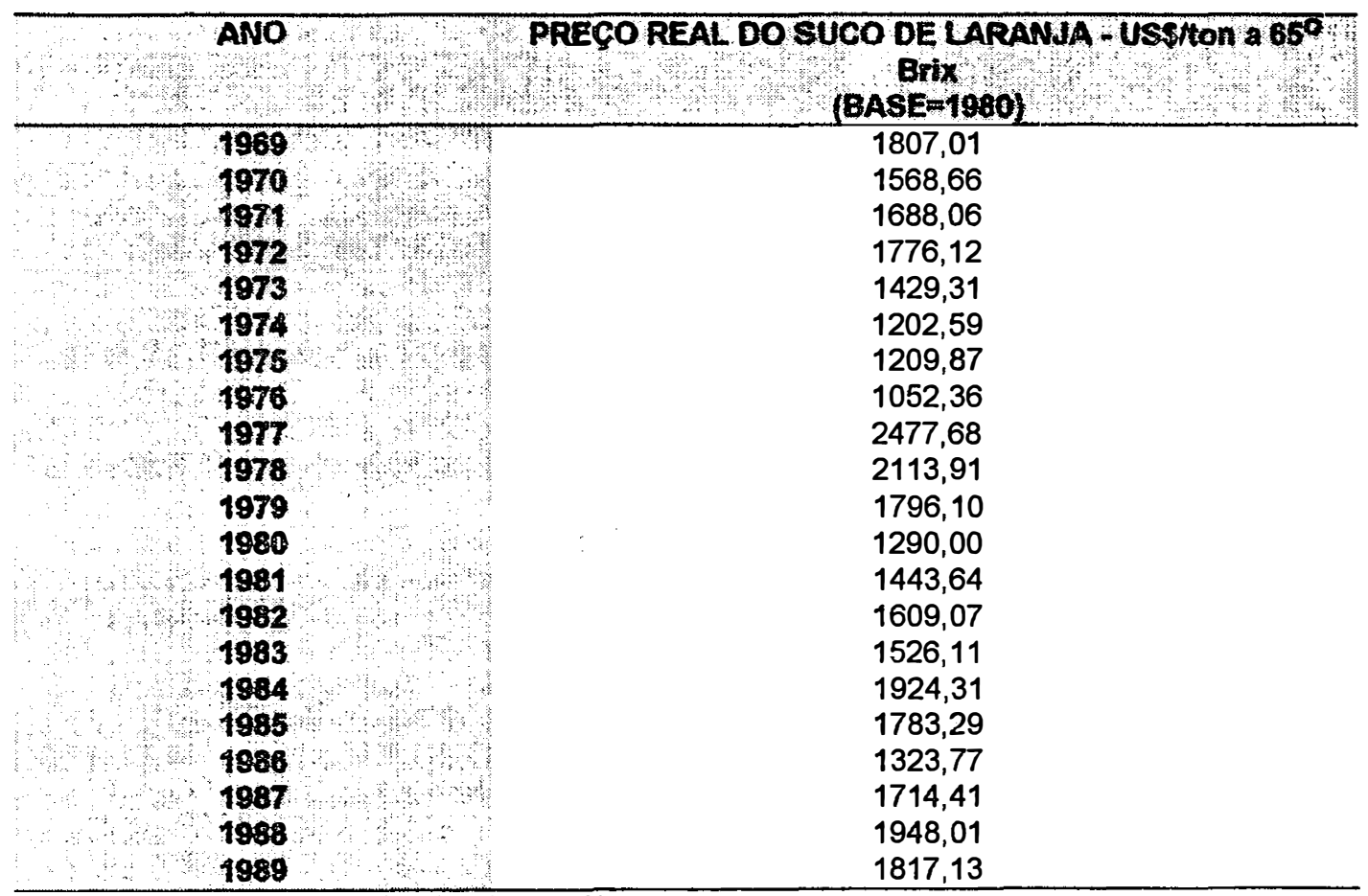

FONTE: Commodity Yearbook - FUNCEX

TAXA DE CÃMBIO - Cr\$IUs\$ ( média anual) e índice de Preços por Atacado nos EUA IPA (média anual).

\begin{tabular}{cccc}
\hline ANO & TAXADE CAMBIO & IPA \\
\hline 1969 & 4,255 & 39,670 \\
1970 & 4,950 & 41,118 \\
1971 & 5,635 & 42,475 \\
1972 & 1973 & 5,934 & 44,366 \\
1974 & 6,126 & 50,164 \\
1975 & 6,790 & 59,621 \\
1976 & 8,126 & 65,131 \\
1977 & 10,670 & 68,133 \\
1978 & 14,138 & 72,285 \\
1979 & 18,063 & 77,960 \\
1980 & 26,870 & 87,746 \\
1981 & 52,699 & 100,000 \\
1982 & 93,060 & 109,168 \\
1983 & 179,390 & 111,306 \\
1984 & 576,160 & 112,704 \\
1985 & 1845,360 & 115,418 \\
1986 & 6200,000 & 114,900 \\
1987 & 13650,000 & 111,500 \\
1988 & 39300,000 & 114,500 \\
1989 & 262800,000 & 119,090 \\
& 2841000,000 & 124,950 \\
\hline
\end{tabular}

FONTE: Conjuntura Económica (FGV); International Financial Statistics (IFS) 
CONDIÇÕES INICIAIS DA SIMULAÇÃO: Distribuição, rendimento e taxa de sobrevivência das árvores por idade.

\begin{tabular}{|c|c|c|c|}
\hline IDADE & $\begin{array}{l}\text { DISTRIRUICAO DAS } \\
\text { ARVORES POR } \\
\text { IDADE* } \\
\text { (mIllBOS) }\end{array}$ & $\begin{array}{l}\text { RENDIMENTO DAS } \\
\text { ARVORES POR IDADE } \\
\text { (caixas de } 40,8 \mathrm{~kg} / \mathrm{pe} \text { ) }\end{array}$ & $\begin{array}{l}\text { TAXADE } \\
\text { SOBREVIENCIA DAS } \\
\text { ARVORES POR IDADE }\end{array}$ \\
\hline novos plantios & 6,17 & - & 0,955 \\
\hline 1 & 1,3 & 0,001 & 0,965 \\
\hline 2 & 2,5 & 0,002 & 0,965 \\
\hline 3 & 3,0 & 0,480 & 0,965 \\
\hline 4 & 1,2 & 1,014 & 0,965 \\
\hline 5 & 1,6 & 1,345 & 0,965 \\
\hline 6 & 2,0 & 1,783 & 0,980 \\
\hline 7 & 2,1 & 2,116 & 0,980 \\
\hline 8 & 2,6 & 2,485 & 0,980 \\
\hline 9 & 2,6 & 2,558 & 0,980 \\
\hline 10 & 2,7 & 2,632 & 0,980 \\
\hline 11. & 0,7 & 2,705 & 0,965 \\
\hline 12 & 0,6 & 2,645 & 0,965 \\
\hline 13 & 0,6 & 2,016 & 0,965 \\
\hline 14 & 0,4 & 1,783 & 0,965 \\
\hline 15 & 0,3 & 1,696 & 0,965 \\
\hline 16. & 0,2 & 1,609 & 0,960 \\
\hline 17 & 0,2 & 1,522 & 0,960 \\
\hline 18 & 0,2 & 1,436 & 0,960 \\
\hline 19 & 0,2 & 1,426 & 0,960 \\
\hline 20 & 0,2 & 1,401 & 0,960 \\
\hline 21 & 0,1 & 1,374 & 0,945 \\
\hline 22 & 0,1 & 1,349 & 0,935 \\
\hline 23 & 0,1 & 1,322 & 0,925 \\
\hline 24 & 0,1 & 1,296 & 0,915 \\
\hline$>=25$ & 0,3 & 1,271 & 0,805 \\
\hline
\end{tabular}

*Tomando-se por base as estimativas sobre a distribuição etária das árvores de laranja realizadas por AMARO (1980) para o início da década de oitenta no Estado de São Paulo, bem como as informações do IEA, segundo as quais havia aproximadamente 32 milhões de pés de laranjas plantados no ano e 6,8 milhões de pés novos com menos de 3 anos de idade, perfazendo $42 \%$ do total de árvores, foi possível estimar, de modo preliminar, a distribuiçảo das árvores de laranja por idade para 0 ano de 1969. Como o objetivo era avaliar o grau de precisão com que o modelo reproduzia o funcionamento real da economia, diversas tentativas foram feitas empreendendo-se a simulação do modelo para o periodo de interesse. Vale ressaltar que esse procedimento foi necessário, em função das limitaçōes impostas pela indisponibilidade dos dados. Neste parte, apresent́a-se a série considerada adequada às exigéncias do processo de simulação, por resultar em menores diferenças entre os valores simulados e os valores observados, para cada variável endógena. 